\title{
From a Moroccan Colony to a North African One
}

Between 1793 and 1814 the Spanish monarchy was wholly at peace during only two years, 1796 and 1803: in all the others it was fighting either France (17931795, 1808-1814) or Great Britain (1797-1802, 1804-1808). Those conflicts formed part of the long cycle of wars provoked by the French Revolution and continued by Napoleon's incursions.

Spaniards, Frenchmen, and Englishmen were involved in all these hostilities, a fact that gave great advantages to ships that sailed under neutral flags. Especially from 1797 onward, when the British Royal Navy blockaded Spanish coasts and ships during the Spanish-English war, sea travel became difficult in general and to nearby North Africa in particular. French and English merchant vessels that had monopolized trade between Spain and Morocco disappeared from that route once their countries were at war with Spain. Spanish ships, though their participation in that traffic was much reduced, did not abandon it altogether in spite of the conflict. Ships of other countries that were not at war began to take over the maritime routes between Spain and North Africa, particularly those of Morocco, Algeria, Tunis, Tripoli, and the Ottoman Empire. ${ }^{1}$ By that time the Spanish crown had signed treaties of peace with all those nations: Morocco (1767), Ottoman Empire (1782), Tripoli (1784), Algiers (1786), and Tunis (1791). While Napoleon's troops were invading Spain North African ships were active in both its ports occupied by the French and those that remained free, especially Cádiz, throughout the war.

In these circumstances, what had been an overwhelmingly Moroccan merchant colony became a North African one with an influx of Algerian, Tunisian, and Tripolitan traders, though none of these formed such a permanent presence as the Moroccans did. In most cases a ship under a Muslim or other foreign flag would make a brief stopover in a Spanish port. It is essential to stress the large increase in the number of ports and cities where the presence of one or more North Africans can be documented between 1767 and 1814. In Map 2 below see the distribution of the Moroccan merchant colony, principally in the capital and in coastal cities.

1 For the phenomenon in general see Panzac, Les corsairs barbaresques, esp. Part 2. We will not deal here with Ottoman-flagged ships that came to Spanish ports during this period, because they were Greek: see Martín Corrales, "Capitaines et navires gréco-ottomans" and "GreekOttoman Captains." 


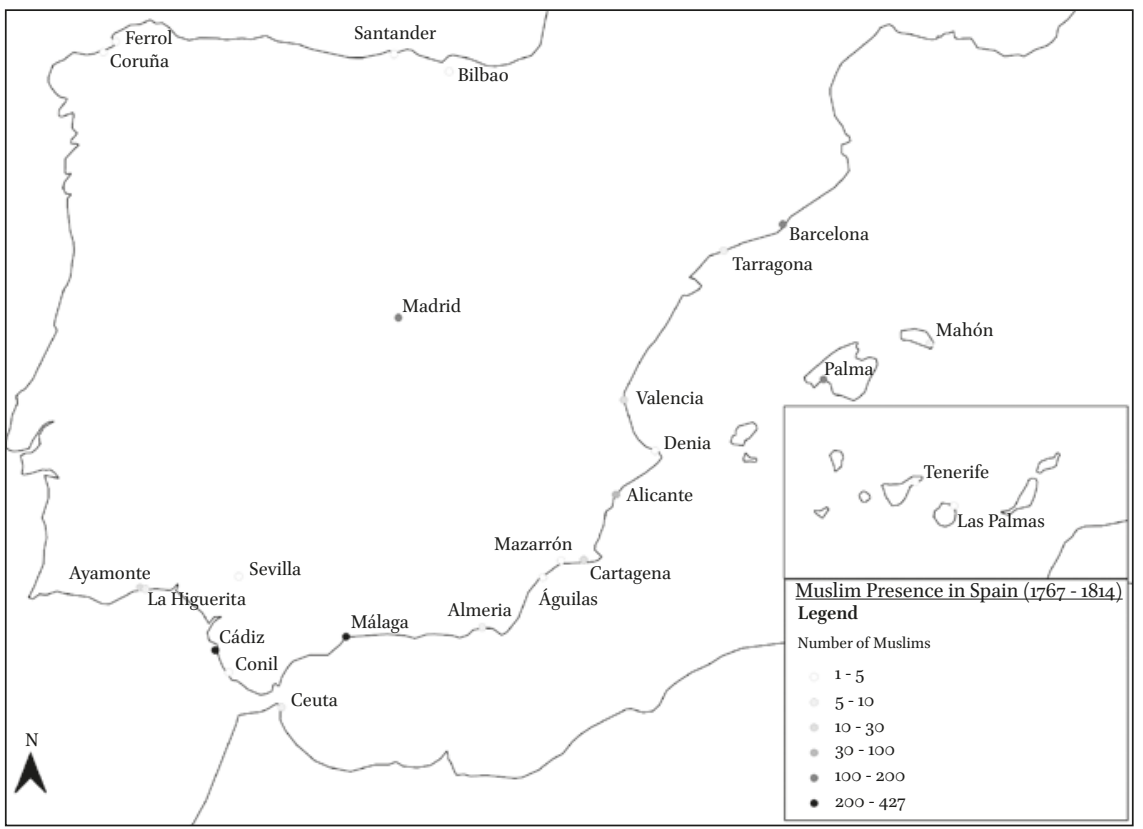

MAP 2 Muslim presence in Spain, 1767-1814

\subsection{A Surge in Maghrebi Ships}

Before the 179 os no Moroccan merchant ships seem to have entered Spanish ports. In October 1786 the kingdom's chief Board of Health asked its local branch in Barcelona how arriving Moroccan ships were dealt with, and received the reply: "In the port of this capital there has been no occasion to adopt any practice with regard to Moroccan vessels, because none has come here." Any ship proceeding from Morocco bearing a passport from the Spanish consul there underwent twenty days of strict quarantine. ${ }^{2}$ In fact, until 1796-1797 very few Muslim ships arrived in Spanish ports, most of them North African corsair vessels in seach of repairs and provisions.

Spain's wars with England (1797-1802, 1804-18o8) and France (1808-1814) allowed ships flying Moroccan, Algerian, and Tunisian flags to participate in direct trade between the Maghreb and Spanish ports. As neutral parties, furthermore, they assumed much of Spanish external commerce and coastal

2 Junta Suprema de Sanidad del Reino to Junta de Sanidad de la Real Audiencia de Barcelona, 25 November 1786, Імн н, Fs, Serie V, leg. 12, fols. 33-36. 
trade. ${ }^{3}$ North African captains and their pursers played an active part in this traffic. We have figures for the period 1792-1813:

TABLE 6 Maghrebi ships arriving in Spanish ports

\begin{tabular}{llll}
\hline Year Cádiz $\quad$ Málaga Barcelona & $\begin{array}{l}\text { Palma de } \\
\text { Mallorca }\end{array}$ & Alicante \\
& &
\end{tabular}

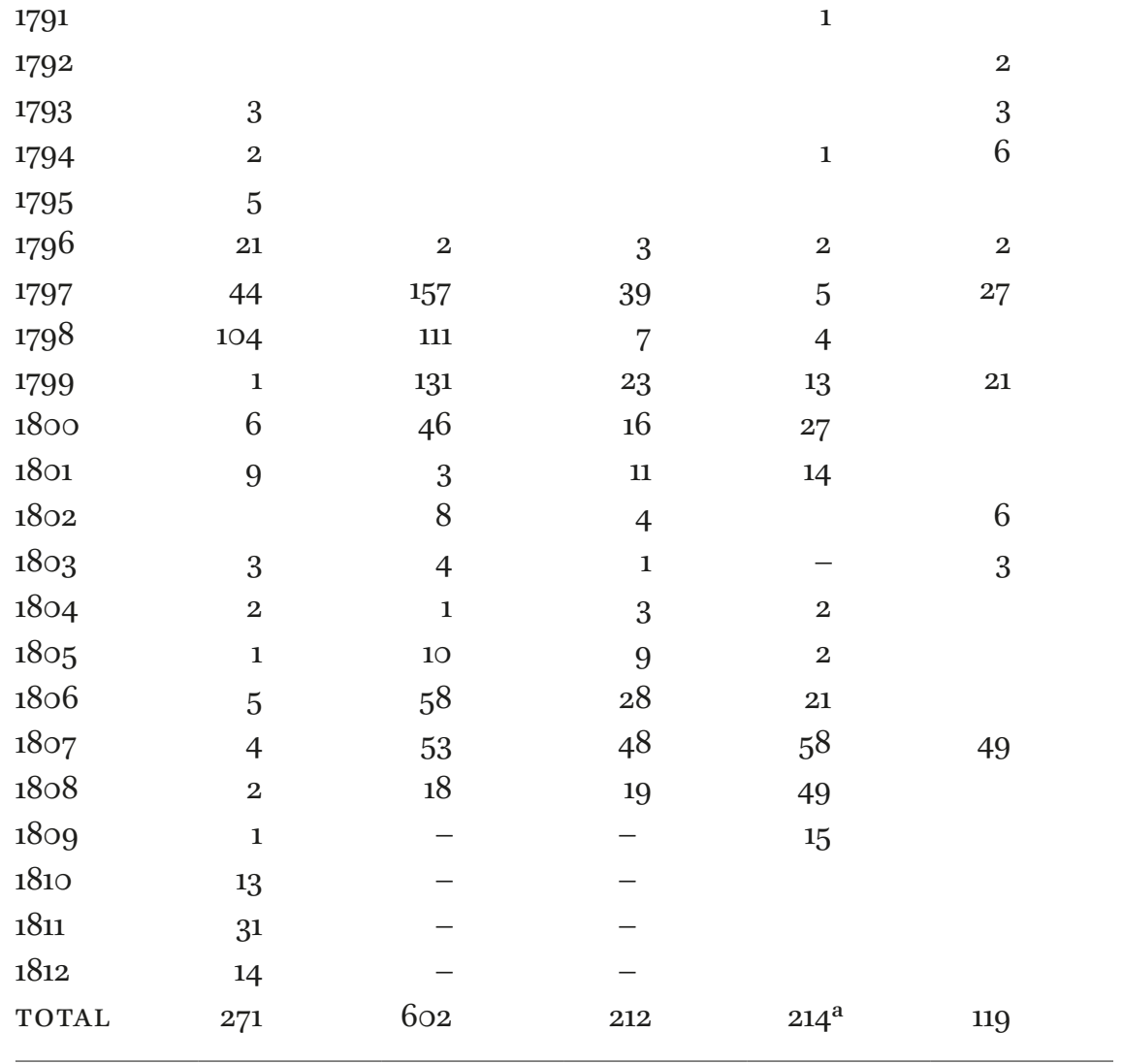

a Moroccan, 15; Algerian, 22; Tunisian, 1: Martín Corrales, "Comercio de las Islas Baleares con el Norte de África"

Sources: For Cádiz, Barcelona, and Alicante: El Diario de Barcelona (1792-18o8), El Correo Mercantil de España y sus Indias (1792-1808). For Cádiz 1810-1812: López Molina, Comercio marítimo, 66. For Palma de Mallorca: Seminario Económico (1791-1809). For Málaga 1786-1794: Archivo Gene-

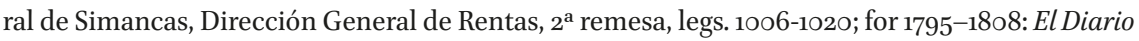
de Barcelona, El Correo Mercantil de España y sus Indias

3 These ships allowed exchanges among ports along the coasts from Barcelona to Ayamonte, and even as far as Portugal and the Bay of Biscay. Of 212 Maghrebi ships that reached 
As we have mentioned, the figures are incomplete because for a variety of reasons the sources are not complete or do not offer information for every year: ${ }^{4}$ those reasons include the wars that blocked maritime routes, and the epidemics of yellow fever that ravaged several southern and eastern Spanish ports, especially Cádiz and Málaga, in the early eighteenth century. There is no instance in which we can add up the figures for each port and arrive at a total number of North African vessels. First, nearly all the ships registered touched at several Spanish ports in one voyage, including, obviously, ships engaged in coastal trade. Second, a large proportion of the registered vessels and captains made several trips to ports in Spain. Third, at least in Cádiz - the principal receiving port together with Málaga - every arriving North African ship was not registered in some years. When the number of ships docking in Cádiz in 1799 was published, it was stated that "the names of some Moroccan [vessels], because the goods they brought to this port were insignificant or they came only with ballast, have not been recorded in the lists." ${ }^{5}$ Some of these irregularities arose during states of war between Morocco, Algeria, Tunis, and Tripoli and European powers, or among the North African nations themselves. Both corsair and merchant ships enter into the statistics, though the latter formed a large majority. Our figures also mix vessels from Morocco, Algiers, Tunis, and Tripoli.

Of course we cannot assume that all these ships were really North African. In many cases they would have been Spanish, and perhaps of some other

Barcelona between 1792 and 1808 only 63 came directly from North Africa; the rest had been trading along the coast or with other European countries: Martín Corrales, "La flotte marocaine."

4 One of the least complete cases is that of Alicante: I have used the Diario de Barcelona which, though wholly trustworthy for the Catalan capital, is much less so for Alicante and Málaga. Those two ports are also imperfectly represented in El Correo Mercantil de España y sus Indias. The collection consulted for Palma de Mallorca, Seminario Económico, lacks several volumes and besides, the figures on ships that entered that port each year do not always add up to the total given in each volume. For example, the volume for 21 March 1801 relates that twenty North African ships (11 Moroccan, 5 Algerian, 4 Tunisian) reached Palma in 180o, but the sum of those registered individually is twenty-seven. Aside from errors in compiling these statistics, some of those ships may actually have been Spanish but sailing under a flag of convenience or of a neutral nation.

5 The total number was published on 20 January and the clarification ten days later: El Correo Mercantil de España y sus Indias, 20 and 30 January 1800. 
country, with a Moroccan captain and crew so as to avoid confrontation with English or French corsairs and warships. ${ }^{6}$

In spite of all this, there was certainly a significant increase in the size of the various North African merchant fleets. In Morocco, for instance, the sultan tried (not very successfully) to encourage the purchase of European merchant ships and attract experienced European sailors who could train Moroccan crews in commercial navigation. ${ }^{7}$ Men of the sultan's court and his Makhzen bought European vessels to stimulate their country's maritime economy, at a period that favored the participation of neutral countries in trade. In 1780 a group of businessmen from Rabat bought a half share in a xebec and sent it with foodstuffs to Gibraltar, ${ }^{8}$ and in the same year Alcaide Abdelmagid Ben Zerak asked Spain to let him go to Gibraltar to buy a ship. ${ }^{9}$ In the previous chapter we also related the purchase - genuine or feigned - of a French vessel by six important men of Rabat. ${ }^{10}$ In the present chapter we will see how Captains Ataib, Hamet Yngles Salazar, and Alhach Malamud Amasaid acquired a polacre in Gibraltar in 1799. Caddur Ben Gileli also owned several merchant ships. In 1799 Alfach Muhamed, a Rabat resident, bought the mistico Envía with all its appurtenances from Juan Capuano of Genoa for ten thousand reales de vellón. ${ }^{11}$ The port of Gibraltar became an important market for ships, thanks to those seized by

6 In 1797 a settee under Captain Josep Pujol arrived in Barcelona from Ayamonte with a cargo of sardines and figs, flying the Moroccan flag: Diario de Barcelona, 7 February 1798 . Also in 1797 the English captured a mistico owned by Alonso de Casas, a scribe from Estepona, which was sailing with "a Moroccan patent and papers claiming falsely that it belonged to subjects of the Emperor of Morocco." It was taken to Gibraltar and declared a legitimate prize. Report without names but probably meant for the military governor of the Campo de San Roque, dated 24 March 1801, AHN, Estado, 5807.

7 Lourido Díaz, Marruecos y el mundo exterior, 106-o8.

8 J.M. González Salmón to Count Floridablanca, Tangier, 4 May 178o, AHN, Estado, leg. 4314.

9 Abdelmagid Ben Zerak asked the Spanish consul to solicit Antonio Barceló, who led the blockade of Gibraltar, for permission to enter that port. The consul did not wish to comply, since "the object of his trip to Gibraltar, according to him, was to buy a ship; and even you suspect that this was a pretext and not his true purpose": J.M. González Salmón to Count Floridablanca, Tangier, 6 May 1780, and Floridablanca to J.M. González Salmón, Aranjuez, 9 May 1780. Shortly after it was learned that the alcaide was aboard a Moroccan sloop that had come from Málaga with a cargo of figs, raisins, and lard and had anchored in Gibraltar: J.M. González Salmón to Count Floridablanca, Tangier, 26 May 1780, AHN, Estado, leg. 4314.

10 Governor Hadgi Abdallah Bargas, his son Meki Bargas, Cassen Reisi, his nephew Taib Reisi, Hach Hamed Fannis (brother of a distinguished alcaide of the sultan), and Captain Ben Embarck. See Chapter 8, section 8.5.29.

11 Archivo Provincial de Málaga, scribe Joaquín Ruiz Rando, leg. 3773, fol. 394. In Málaga in 1810 the Algerian Alí Solimán bought the felucca San Juan from José Aguirre for 25,000 reales de vellón: APM, scribe Francisco Joaquín Zumaque Rueda, leg. 3852 . 
English and other foreign corsairs, so that a good number of North Africans went there to make their purchases. ${ }^{12}$

Algiers, Tunis, and Tripoli also sought to develop merchant fleets devoted to trade. ${ }^{13}$ All these countries gained larger shares of direct commerce between the two shores of the Mediterranean, to the detriment of the clear dominance that England, France, and Spain had previously enjoyed. Yet Morocco was frustrated in its efforts to create a true merchant marine. ${ }^{14}$

\subsection{The Spanish-Moroccan Treaty of Peace of 1799: Adjustment to a State of War}

In previous pages we have spoken of the importance of Spanish-Moroccan trade from 1767 onward. As we saw in Chapter 8, almost all exchanges were performed with ships and merchants from Spain and other European countries, while those from Morocco were late in appearing in Spanish ports. There were, naturally, some incidents and conflicts (as happened with Spaniards in Morocco as well). Relations between the two countries grew tense at two specific periods that culminated in the brief wars of 1774-1775 and 1790-1791, and to resolve these problems their monarchs entered into new negotiations that culminated in the Treaty of Peace, Friendship, and Trade of 1799. It was an explicit continuation of earlier treaties, as its first article states: the Treaty of 1767 , the Agreement of 1780, and the Arrangement (Arreglo) of 1785 "are renewed and confirmed in all that is not contrary to the present treaty." Its thirty-eight articles prove that both sides wished to avoid any negative consequences on their mutual alliance from mercantile issues; this new pact sought to lessen the impact of disagreements that might arise in the future. Twelve articles are devoted exclusively to commercial matters, which appear in a few others as well. Specifically, it was made clear that "Moroccans in Spain will pay the same fees of import and export on goods they own, whose exit and entrance is permitted, as they have up to the present time" (Article 26). The related Articles 27, 28, and 29 fix the import and export duties that Spaniards would pay in Moroccan ports. Article 32 established the anchorage fee. Several more were concerned with sea travel, e.g., "Merchant ships of both nations may anchor in the ports

\footnotetext{
12 Marina Alfonso, "La procedencia de la flota del Libre Comercio."

13 Panzac, Les corsairs barbaresques.

14 For the difficulties in establishing Maghrebi merchant fleets see, aside from works by Lourido Díaz and Panzac already cited, the classic studies by Mathiex, "Sur la marine marchande barbaresque"; Emerit, "Essai d'une marine marchande barbaresque."
} 
of the other if they are furnished with papers from the proper authorities" (Article 16). Two articles referred to problems caused by corsairs of third nations. Article 19 stated that Moroccan corsairs had to free Spaniards and their goods from third-country ships they captured:

As proof of the good harmony that should prevail between the two nations, if Moroccan corsairs should seize any enemy vessel that carries Spanish sailors or passengers, merchandise, or any other property of subjects of His Catholic Majesty, they shall release them to their consul general with all their goods and effects.... Spanish ships shall do the same with the subjects of His Moroccan Majesty that they may encounter in captured enemy ships.

By extension, the rule required

granting freedom to the subject persons and goods of powers that are enemies of either one of our countries, who sail in Spanish or Moroccan ships with legal passports that make clear what baggage and effects belong to them, unless those should be forbidden by the laws of war.

Under Article 20 there could be no sale of either Spanish ships seized by enemies of Spain and taken to Morocco or Moroccan ships seized by enemies of Morocco and taken to Spain; their crew, passengers, and cargo were likewise protected. Article 25 stipulated that there could be no claim for "restitution of Muslims from any country who were brought to a Spanish port in a Moroccan warship."

An important provision was the sultan's concession to Madrid's Five Guilds (Compañia de los Cinco Gremios Mayores) of exclusive rights to export grain from Casablanca, "Paying sixteen reales de vellón for each fanega of wheat and eight for each one of barley, thus continuing in force and value the agreements to the purpose that have been made previously with His Moroccan Majesty" The door was left open to the Spanish monarch's extending that privilege to any subjects he wished. The text explicitly recognized this right as a gift: "His Moroccan Majesty shall declare that he offers exclusive rights in that port not out of respect for the said company but as a gift to the king of Spain." The same Article 30 granted similar rights to the Benito Patrón company of Cádiz.

It is significant that, if the Moroccan sultan were to find "some just motive for forbidding the export of grain, or any other commercial goods or effects, 
from his domains," the measure would not affect any grain or merchandise that Spaniards might have purchased before the prohibition (Article 31). Under Article 33, hemp fiber and timber could be exported to Spanish shipyards.

Several articles reflect the wishes of both nations that their subjects not cause problems or commit crimes in the allied country. Moroccans traveling to Spain had to show passports issued by the Spanish consul in Tangier or the vice consuls established in other Moroccan ports, and without them could be denied entrance:

Those who do not present such documents will not be admitted on any pretext. But if they possess them in good order they shall be offered every protection and surety, and the government shall ensure that they not suffer any ill treatment or vexation, punishing severely anyone who interferes with them; and to this effect His Catholic Majesty shall issue the strictest orders to the governors of the various ports. (Article 3)

In matters of trade there were provisions for breaches of agreements or contracts by either side, "in every claim over payment of debts, fulfillment of a contract, or any kind of disagreement." Moroccans must appeal to Spanish authorities if they had been treated unjustly, since there was no Moroccan consul in Spain: "The administration of justice must be reciprocal and performed in good faith as a firm principle of friendship and good harmony between the two nations" (Article 5).

Other articles addressed violations of Spanish law. Measures were taken to prevent smuggling by Moroccans on Spanish soil and by Spaniards in Morocco:

Any Moroccan apprehended with contraband goods in the act of taking them in or out of a port in Spain shall be sent as a prisoner with his goods to the Government of Morocco, with a report to the Consul General so that he may be punished in proportion to his offense. But if the goods belong to a Christian they will be retained and decommissioned in Spain, sending only the perpetrator. Should a Moroccan subject arrive at a [Spanish] port with goods of this kind or introduce them not knowing they were prohibited, he must declare them; otherwise he shall be subject to the punishment described above. (Article 34)

A separate article decreed that goods to be traded had to be declared at customs: 
Therefore both Spaniards and Moors who engage in trade between Morocco and Spain must declare in the customs houses of His Catholic Majesty, by means of a certificate from the Consul General, vice consul, or commissioner in a Moroccan port, the goods and effects that leave the latter for [Spain], [stating] exactly where they will be introduced. Without this they shall receive no reduction in the duties described in Article 28 and will pay the same as other nations who do not enjoy the privilege. (Article 38)

Moroccans who committed any "scandal, insult, or crime" in Spain were to be turned over to the Spanish consul in Tangier, with no more than a written notice from the local Spanish authority; Morocco would then impose the appropriate punishment. Spain would protect the goods of any Moroccans who died in Spain. Citizens of the North African nation could buy land in Spain and build on it, then rent their buildings on whatever terms they wished. They could not be forced "to lodge or maintain anyone in their homes." They enjoyed limited religious freedom: "Moroccans living in Spain may perform privately, as they have up to now, the acts required by their religion." They could leave Spain at any time, so long as they had paid their debts and settled their affairs; otherwise, they would have to answer to the Spanish consul and vice consul. ${ }^{15}$ Spaniards in Morocco were assured of the same treatment as Moroccans in Spain, who in turn enjoyed in that country the same privileges as any other foreigners. While all these measures were well intentioned, the mechanisms for overseeing them and imposing the appropriate punishments were not always effective.

\subsection{Spanish-Moroccan Cooperation to Prevent Smuggling}

The concern about smuggling in the Peace Treaty of 1799 was entirely justified. During Spain's war with England in 1797-1802, Moroccan captains and traders saw a golden opportunity to enrich themselves by supplying food to Gibraltar, blockaded by the Spanish army and navy. They were not the only ones guilty of such activity: in most cases North Africans were acting as agents for European, especially Spanish, merchants. Below we will examine the cases of Captains Tuffe, Haslem el Rubio, Absalem el Jedit, Hamet Ford, Abdasalem Buasa, and Hamet Absalem. 
It is not surprising that Spanish authorities were so worried by the new contraband activity involving Gibraltar. In July 1798 the Spanish consul in Morocco told the Count of Cumbre Hermosa, the assistant tax collector in Cádiz, that he had been ordered to prevent Gibraltar's provisioning with goods from Morocco: "the enemy are very short of these necessities, especially sheep, and try to obtain them by all possible means." The consul knew that "some feluccas flying a Moorish flag have loaded up with those animals, ship's biscuit, and other kinds of refreshments for Gibraltar, moved by the great wealth that these can earn them." To conceal this traffic, captains filed customs documents that claimed the goods were bound for Ceuta. To prevent such actions, the consul advised customs inspectors

not to provide papers to any Moroccan ship loaded with foodstuffs that claims to be bound for one of the ports along our coast, or for Ceuta (I understand that they load them in El Puerto de Santa María or Isla de León). If these precautions are not taken we will be the ones who are indirectly supplying our enemies with goods that they need badly.

He thought that Moroccans were merely lending their names to the enterprise, at least in the first years of the war: "the Moors need only provide their names, for I presume the business is done by Christians." But since real Moroccan ships also participated in the illicit trade, he suggested that

the Coast Guard's feluccas watch for Moroccan vessels that sail from this bay [of Cádiz] or from Santi Petri; and if they find one loaded with victuals they detain it and inform me. Then I can send the captain or captains who commit this offense as prisoners to Tangier, where they will surely be punished severely by their sovereign, for he is determined that the English not receive this type of aid. ${ }^{16}$

16 “...no habiliten de Papeles a ninguna Embarcación Marroquí que con carga de Viveres diga que ba para alguno de los Puertos de nuestra costa, para Ceuta, (que según tengo entendido los cargan por el Puerto de Santa Maria, ó Ysla de Leon), pues de no tomar estas precauciones se verifica que Nosotros mismos somos los que indirectamente proveemos a nuestros enemigos de unos renglones que, les estan haciendo suma falta. ... [S]e previniese a los Faluchos del Resguardo para que vijilen sobre los Barcos Marroquies, que salgan de esta Bahia, o por Sti.Petri, y si se aprende alguno cargado de refrescos, se detenga y se me de parte para mandar al Arraez ó Arraezes, que incurran en este delito, arrestados a Tanger, que seguramente serán castigados con el mayor rigor por su soverano, pues justamente está empeñado en que los Yngleses carezcan de estos auxilios": marked "Private," J.M. González Salmón to Count of Cumbre Hermosa, Cádiz, 20 July 1798, AHN, Estado, leg. 4340. 
The consul told the Secretary of State of his efforts to put an end to the practice, "news having reached me that some ships flying the Moroccan flag but of Spanish ownership are carrying refreshments to Gibraltar." He also informed the squadron commander, José de Mazarredo, "in case one of them can be caught." But he was aware of the difficulty of thwarting this activity in light of the large profits to be made from selling North African foodstuffs in Gibraltar: "a pound of mutton there has sold for fifteen reales and a pound of beef for twenty-four, of the small amount that reaches them from Arzew."17 Still, the consul hoped that preventive measures would be approved. ${ }^{18}$

The Spanish consul reminded the Secretary of State of the policy applied in 1798 to Moroccan ships that tried to enter Gibraltar with provisions. Spain had not notified the sultan formally "that we consider the port of Gibraltar blockaded by us, and therefore hold as a legitimate prize any effects that neutral nations bring to it." Therefore the Secretary should order that Moroccan vessels not be stopped, only "Moorish boats". 19

Naturally enough, problems arose from this incomplete blockade (which was not communicated to all the interested parties), initiated by the Spanish and exploited by Moroccans who, as neutral traders, could profit from the ambiguous situation. In September 1799 the governor of Tangier complained of "a Moroccan tartane that, on its way to Gibraltar with a load of oxen, was detained by a mistico of the king and taken to Algeciras." The oxen, he said, belonged to Moroccan subjects who were shipping them "as payment for the gunpowder that the English gave them to satisfy export duties." He wanted them returned, "especially since this has happened at the beginning of [my] service in the honored post that his sovereign Muley Soliman has conferred on [me], that of Director of Foreign Trade." The consul, as he waited to hear to whom the animals really belonged, suggested to his superior that they "force the captain to sell the cattle in Algeciras, or at least urge him to go to Tangier."20

17 J.M. González Salmón to Francisco de Saavedra, Cádiz, 20 July 1798. There were many complaints about the behavior of "bad Spaniards" who supplied Gibraltar: J.M. González Salmón to Francisco de Saavedra, Cádiz, 4 September 1798, AHN, Estado, leg. 4340; also J.M. González Salmón to Mariano Luis de Urquijo, Cádiz, 3 May 1799, AHN, Estado, leg. 4341.

18 On the same subject, and on sales of gunpowder to the English by the Spanish squadron: J.M. González Salmón to Mariano Luis de Urquijo, Aranjuez, 1o June 1799, no. 92 (on the same subject as no. 68). J.M. González Salmón to Mariano Luis de Urquijo, Aranjuez, 10 June 1799, no. 93 (on the same subject as nos. 68 and 92).

19 Presumably, from other North African countries: J.M. González Salmón to Mariano Luis de Urquijo, Tarifa, 21 September 1799, AHN, Estado, leg. 4341.

20 J.M. González Salmón to Mariano Luis de Urquijo, Tarifa, 21 September 1799, AHN, Estado, leg. 4341. 
It hardly mattered if the cargo belonged to the English or the Moroccans; the point was that "this sort of traffic is useful to [the latter]." It was best to be flexible in this case "because safeguarding the Moroccan flag against the English (who also use it sometimes) better protects our commerce."

The prudent course, he concluded - "since we do not enjoy superior force in those waters" - was to set the prize free; otherwise Spain would not gain "the principal object of preventing supplies from reaching the enemy port." That task could be assumed by the English fleet on its own or as escorts to Moroccan supply ships. In either case, "without wishing to we tacitly reveal to the Moors our inferiority at sea, and indirectly allow them to be angry with us because they think we oppose their use of that trade." If the prize were returned to the Moroccans "as a considerate act" Spain would preserve "our commerce, which still operates under the Moroccan flag between our own ports." The gesture would strengthen Spain's request to Muley Sliman that he demand English respect for "said flag in ships that leave or enter our ports, in exchange for the freedom we allow it when sailing to Gibraltar." If the English declined to impede "ships of His Moroccan Majesty that traffic in our Peninsula, that sovereign will not object nor will he make claims on those of the same class that we may intercept as they enter Gibraltar." Once the case was explained at court, the king ordered that "the captain be made to sell his cattle there, leaving the ship and its crew at liberty." The captain was allowed to continue his journey. ${ }^{21}$

We cannot tell how many Moroccan ships, or ships displaying that flag, tried to evade the Gibraltar blockade. José Coronel, commander of the corsair felucca Vigilante, heard that the Misiana under Captain Hach Hamet Absalem had been detained and remarked that he engaged in the same trade, like others who flew the same flag: "several Moroccan boats and cargoes have been taken as legal prizes." 22

Other Moroccans were detained for the crimes of smuggling, non-payment of debts, fraud, etc., ${ }^{23}$ but Spanish authorities, while confiscating their goods,

21 J.M. González Salmón to Mariano Luis de Urquijo, Tarifa, 21 September 1799. A note on the cover of the file reads: "Let it be stated that this prize may be sold in the place where it is held, giving the sale price to the Moroccan, with which all is concluded; let orders for this be given and let the consul be advised of the decision": AHN, Estado, leg. 4341.

22 José Coronel to Count de la Haye St. Hilaire, Algeciras, 20 February 1800, AHN, Estado, leg. 5803 .

23 As an example, in Alicante in 1800 Captain Miquessi, a Moroccan, had four barrels of tripe confiscated for not having paid duty on them. He was suspected of being one of many Moroccan captains who were trading with Gibraltar in spite of its blockade. For reasons of political convenience, however, the tripe was returned to him "out of our lord King's sovereign consideration for His Moroccan Majesty," and of course the sultan was informed of the gesture: Antonio González Salmón (substituting for his brother Juan 
usually did not impose the penalties called for in the Treaty of Peace. They were not turned over to the sultan for fear that their punishment might be too severe. The Secretariat of State, local governors, and especially the Spanish consul in Morocco would try to have the sultan himself, his ministers, or his alcaides or governors promise that the guilty man would be spared the worst. Their motive was to create no enemies while retaining friends and allies who could defend Spanish interests in Morocco.

At this point the sultan acted to limit sharply any possibility of forming a Moroccan merchant fleet. In 1799 he forbade any ship flying the Moroccan flag to engage in foreign trade, and ordered the return of those that were abroad:

At the end of 1799 His Moroccan Majesty forbade all sailing under his flag in the seas and ports of Europe. He reduced [the ships' range] to that of his own domains, granting a stay of six months to the vessels that were far away. He informed the diplomatic corps in Tangier of this decision so that each member could make it known to his own government, to avoid the repeated abuses that were being committed under the shelter of that flag.

Once the period had elapsed, the ministry Your Excellency heads sent out the necessary order so that in our ports no items at all would be loaded onto Moroccan ships bound for other ports in Europe.

The Spanish press of the time took note of a measure so damaging to Morocco's maritime economy. The Semanario Económico, Instructivo y Comercial of Palma de Mallorca printed the royal decree, which stated that the sultan,

to avoid continual claims for return of property intercepted or confiscated from ships flying the Moroccan flag, was going to withdraw his patents and thereby cut off his commercial navigation in Europe, by ordering that his ships be employed in nothing else but carrying products of his country, belonging to his subjects, from one port to another in his own domains. But he granted a period of months for ships that were sailing in distant waters, so as not to harm the interests of nations that might have goods among their cargoes. ${ }^{24}$

Manuel as Spain's consul in Tangier at the time) to Secretary of State Mariano Luis de Urquijo, 4 March 180o, AHN, Estado, leg. 4358.

24 "A fines de 1799 prohibió S. M. Marroqui la Navegacion de su Bandera en los mares y puertos de Europa, y la reduxo á los de sus Dominios, concediendo seis meses de plazo para los buques que se hallasen distantes, noticiando ésta Providencia al Cuerpo Diplomático en Tanger, con objeto á qe cada Empleado la hiziese saber á su respectivo Gobierno para evitar los repetidos abusos que se cometían al abrigo del mencionado Pabellón. Cumplido el 
The sultan asked European countries, once that period had elapsed,

not to allow any ship flying the Moroccan flag to be loaded in their ports, but to oblige them to return to their country, those vessels being the legal property of Moors. And since there are many Europeans with false contracts of sale in favor of Moors, Moroccan passports should be taken away from all those who hold them; their Moorish crewmen should be made to disembark and should be sent back to their own country.

The Semanario reported, however, that Moroccan-flagged ships continued to sail in Spanish waters even after the grace period had expired. ${ }^{25}$ Cádiz's tax collector was holding up a Moroccan ship being loaded in his port with products for Morocco:

A Moorish ship came to this [city] a few days ago from Tangier with the proper authorization from that government, bringing silver coin to invest in products of our Americas and the Peninsula such as cochineal, sarsaparilla, saffron, Barcelona silk kerchiefs, etc., that were destined for the same port of Tangier. Your Excellency's penetrating mind can understand how much it pleases us that any enemy nation should bring cash to our country to buy a surplus of our products.

Once most of the cargo was on board the Moorish ship and it prepared to return to its country after serving the quarantine, this government took notice of the abovementioned order not to load anything under a

referido término, circuló ese Ministerio del cargo de V.E. la correspondiente orden, a fin de que en nuestros Puertos no se cargase efecto alguno en Barcos Marroquies para otras Plazas de Europa....[P]ara evitar las continuas reclamaciones sobre restitución de propiedades interceptadas ó confiscadas baxo pabellón Marroquí, iba á retirar sus patentes, y cortar de este modo su navegación mercante en Europa, mandando que sus buques no se empleasen mas que en conducir de un Puerto á otro de sus dominios las producciones del país y propias de sus súbditos; pero que concedía el plazo de meses en favor de los buques que se hallasen navegando en parages remotos para no perjudicar los intereses de las potencias que pudiesen tener efectos embarcados en ellos": Semanario Económico, 2 August 1800 .

25 “...no permitiesen que en sus Puertos se cargase Buque alguno baxo pabellón Marroquí, sino que los obligasen à volver á su país siendo las embarcaciones propiedad legitima de Moros; y que siendo de pertenencia de Europeos (como hay muchas) con contratas simuladas de venta en favor de los Moros, se retiren los pasaportes Marroquíes de manos de quien los tenga, se hagan desembarcar las tripulaciones Morunas, y se las obligue à regresar à su tierra": Semanario Económico, 9 August 1800. 
Moroccan flag; and the director of customs here refused to allow the rest of the purchases to be loaded.

The Spanish consul in Tangier believed that these actions harmed Spain's interests; it was better to facilitate such purchases, after ensuring that they were actually bound for Morocco. Therefore, "foreseeing the ill will the Moroccans would feel from such a refusal on our part," he asked the city's governor for permission for those purchases to be made. The latter "agreed to my suggestion at once, but since new cases like this one may arise" wished the Ministry of the Treasury to

issue an order to our customs houses that, when the proper health precautions have been taken (though plague has been eliminated in the whole Kingdom of Morocco), they allow goods to be loaded under the Moroccan flag, when those goods are bound for those domains, on the sole condition of requiring a deposit and the return of an official guide certified by the vice consuls and commissioners of His Majesty in the ports of that kingdom. ${ }^{26}$

\subsection{Continuity of the Moroccan Merchant Colony}

The colony of merchants from Morocco continued to be the largest one, with some members established in Spain for long periods; it eventually grew to include many ports as well as towns in the interior. It was perhaps not as

26 "Llegó días pasados de Tanger á ésta, y con la competente habilitación de aquel Gobierno, un Buque Moruno, trayendo plata efectiva para imbertirla en frutos de nuestras Américas y Peninsula, como son grana, Zarzaparrila, Azafran, Pañuelos de seda de Barcelona, \& cuyos renglones iban destinados al mismo Tanger. De esto puede colegir la sabia penetración de V.E. quan agradable nos debe ser el que qualqueira Nacion amiga trayga Numerario á nro. Pais para comprar el Superfluo de nuestras producciones. Teniendo ya la mayor parte de su cargo á bordo el enunciado buque Moruno para regresarse en qüarentena á su tierra se tubo presente, por parte de éste Gobierno, la orden, arriba expresada, de no cargar cosa alguna baxo Bandera Marroqui, y se negaba el Administrador de ésta Aduana á dexar embarcar el resto de lo comprado. ... [P] ase orden á nuestras Aduanas á fin de que, usando la Sanidad de las correpondientes precauciones (no obstante haberse extinguido enteramente la peste en todo el Reyno de Marruecos), dexen cargar efectos baxo el Pabellon Marroqui, quando dhos renglones vayan con destino á aquellos Dominios, sin mas condición que la de exigir fianza y vuelta de guía legalizada por los Vice-Cónsules y Comisionados de S.M. en los Puertos de aquel Ymperio": A. González Salmón to Pedro Ceballos, Cádiz, 10 February 1801, AHN, Estado, leg. 5821. 
permanent in this period as in the earlier one, since most of its members moved back and forth between Spain and Morocco. Corsair captains sometimes joined it as commanders of merchant ships and even as traders. The sorts of troubles they were involved in were much the same as in the three previous decades. Here again, an account of its individual figures and the difficulties they caused will fill out the picture we have been drawing up to now.

\subsubsection{Arráez Tuffe (1796-18oo)}

Captain Tuffe, ${ }^{27}$ "a pilot in war and a vassal of the king of Morocco residing in Cádiz," sent a petition to the Secretariat of State:

Since the year [17]96 he had sailed in the post of captain in the Moorish mistico El Mesouda out of Salé, which he owned, bringing successfully into that port - even during the blockade - cargoes of Barbary wheat and other foodstuffs that he collected in Moguer, through the Five Guilds and others that supplied the squadrons of His Catholic Majesty.

In 1800 he sailed from Ayamonte to Reus (in Tarragona) with a load of sardines on behalf of Spanish merchants. After arriving he learned of the sultan's order that Moroccan captains must return home, and he tried to profit from his homeward journey by taking on paper and hazelnuts in Tarragona, Salou, and Barcelona, on account from Spanish traders, which would be delivered to their purchasers in Cádiz. His papers confirmed this plan, even though "to protect Spanish property from risk by [Spain's] enemies he brought documents stating that the whole cargo was his own property."

On 27 May, off "Tanginola, six miles out to sea,"28 he was intercepted by an English corsair who ordered him to proceed to Gibraltar and placed three of his own men on board. The captain and his coastal pilot, a Spaniard named Antonio Macías, changed course while the Englishmen were asleep and headed for Estepona in search of refuge; but three miles from their destination the English corsair realized what was happening and fired on the mistico in an attempt to stop it. He abandoned the chase, however, when two armed Spanish feluccas, the Escorpión and the Vigilante, appeared. After a five-day quarantine the feluccas' commander ordered the pilot of the mistico to turn over the cargo, and on being refused had the captain and crew imprisoned. The captain

27 He also appears as Yuffe.

28 This place name has not been identified, but might be Fuengirola. 
claimed that sailors from the felucca had insulted the Moroccan flag, "trampling and slashing it."

Once freed from prison the captain sailed to San Roque to demand the return of his ship and crew from the military governor of the Gibraltar region (Campo de Gibraltar), but he was not received and his protest went unheard. His Spanish pilot fared no better after repeating the appeal and stressing his knowledge of the circumstances, while claiming to be responsible for the cargo to its owners; besides, he was threatened with prison if he returned to Estepona. The captain and pilot decided to go to Cádiz "to inform the interested parties of the operation." The captain noted that the ship flew a Moroccan flag that had been offended:

And this - in spite of the proper orders of His Catholic Majesty - is the answer to the generosity of a vassal of a friendly power that, as a neutral nation, redoubles its efforts to preserve the property of Spaniards: ... the Moorish flag has been mistreated, and the sailors of the feluccas have mocked aspects of the religion that the crewmen of the mistico profess.

He added that the affair would cause "displeasure to the king my master, from whom these facts cannot be hidden": especially, that the ship and its cargo had been taken as a prize "without hearing from the interested parties." The captain and pilot, "risking the loss of everything, had decided to flee from the English corsair and approach the Spanish coast"; therefore the Spanish feluccas had not performed a recapture, which would have legitimated the prize. They did admit that in the worst case, since they had been seized for less than twenty-four hours, they would have to pay a fee to be agreed on with the cargo's owners. Spain's consul general in Morocco, Antonio González Salmón, had been apprised of the matter. The petition ended with a request for restitution of all the confiscated goods with payment for damages, and "satisfaction for the outrage performed by the sailors on the Moorish flag." 29

29 "[D]esde el año de 96 navegava en calidad de tal Arraez con el Mistico Moro de Salé, nombrado el Mesouda, de su propiedad, introduciendo en dicho Puerto felizmente, aun en el tiempo del Bloqueo muchos cargamentos de trigo de Berveria, y otros viveres que hacia en Moguer, por cuenta de las Casas de los Cinco Gremios y otras que servían para el abasto de las Esquadras de S. M. C. ... [A]si es correspondida, bien a pesar de los justos encargos de S. M. C., la fineza de un vasallo de Potencia Amiga, que redobla los esfuerzos por salvar bajo su nombre neutral las propiedades de Españoles. ... El Pavellon Moro ha sido ajado, y aun ridiculizadas por otras gestiones de la Marineria de los Faluchos ciertas previsiones que dicen relación á la observancia de la Religion, que profesa la del Mistico": Petition by Captain Tuffe signed in Arabic, Cádiz, 27 June 180o, AHN, Estado, leg. 5820. 
The Secretariat of State asked the commander of the Spanish feluccas to explain himself. ${ }^{30}$ Captain José Coronel of the Vigilante insisted that the mistico had been seized legally and that his sailors had not insulted, slashed, or trampled the Moroccan flag. He had ordered the mistico unloaded because it had sprung a leak, and its captain had been told to keep a record of the cargo, which would be warehoused with one key for him and one for Coronel until the matter was settled. He, Coronel, had obeyed the corsair rules whereas the Moroccan captain "insulted me in a thousand ways in front of the Board of Health of this city; he refused to witness the unloading and departed at once for that headquarters."

The remaining Moorish crewmen, who did not wish to stay on board or assume any responsibility for the goods being unloaded, took up lodging in an inn of this town, where they were supported with four reales de vellón per man per day. The Moroccan flag was kept flying from the mistico's mast until the ship and cargo were declared a legitimate prize. At that point, a judgment having been made, its contents were sold and distributed in accordance with royal decrees. ... [The captain] argues only about supposed insults, and changes the facts completely; and I must not fail to defend a group of sailors who so often have shown proper consideration and respect for our neutral and friendly powers, as well as a most intrepid spirit against enemies of the Crown. ${ }^{31}$

Finally the Secretariat of State told the military governor in Gibraltar that it approved "everything that has been decided in that tribunal,"32 while that official assured him that he could prove that the Moroccan captain's account was false, speaking of

30 San Ildefonso to the military governor of the Campo de Gibraltar, 4 July 1800 , AHN, Estado, leg. 5820.

31 "[L]a restante tripulación moruna, que no quiso mantenerse a bordo, ni llevar quenta alguna de los Efectos que se desembarcaban, se alojó en un Meson de esta villa, y la socorrió diariamente, con 4 reales de vellon por individuo, dejando el Pavellon Marroqui arbolado en el Mistico, hasta que declarado Buque, y Carga, por de buena presa, y pasado ya en autoridad de Cosa Juzgada, se bendio y repartió su importe con arreglo a las Reales Ordenanzas. ... [S]olo se apoya en supuestos ultrages recibidos, y en variar enteramente los hechos; y esto me obliga a omitir la justa defensa de una marineria, que en tan repetidas ocasiones ha manifestado tanto la debida contemplación y respeto a nuestras Potencias neutrales, y amigas, como el mayor espiritu e intrepidez, contra los enemigos de la Corona": José Coronel to Count de la Haye St. Hilaire, Estepona, 14 July 180o, AHN, Estado, leg. 5820.

San Ildefonso to military governor of the Campo de Gibraltar, 31 July 1800. 
the falsity the Moor commits, and the great moderation and propriety that this good officer [José Coronel] has shown: offering daily proof of his activity, knowledge, and zeal, with the various seizures and recaptures he has performed. One of them was the ship that the said arráez sailed in, and my Council of War declared it and its cargo a good and legitimate prize and its value was paid out according to His Majesty's decrees, the parties consenting to the sentence without presenting an appeal. ${ }^{33}$

He ended by recalling a very important factor in such incidents: that the sentence conformed to royal decrees about the taking and retaking of prizes, intended to ensure that "prize-takers not be denied frequent opportunities to be compensated for their risks and efforts." ${ }^{4}$

\subsubsection{Haslem el Rubio (1797)}

This captain of a felucca named El Sid or Sahin weighing $45^{\circ}$ quintales petitioned the Secretariat of State in March 1797. Together with Carlos Grima, a businessman from Cádiz, he had chartered a ship intending to sail to the Bay of Gibraltar and take on whatever cargo the charterer desired. From there he would make a brief layover in Tangier to obtain the necessary documents and then continue on to Cádiz. If he did not load a full complement in Gibraltar - where his sixteen-day stay would cost him five pesos fuertes per day - he could fill the rest of his hold in Tangier. The captain had been forbidden to load any cargo belonging to himself or anyone other than the charterer. On arriving in Cádiz he was to receive 250 pesos fuertes and a supplement of five more, while the port and anchorage charges would be paid by the ship. ${ }^{35}$

On 6 April 1797 the Moroccan felucca, on its way from Gibraltar to Tangier, was detained by launches from Algeciras and a goulette of the Spanish navy under Article 88 of the rules of the royal fleet. The Algeciras Board of Health

33 “...la falsedad con que se produce el Moro, y de la mucha moderación, y arreglo con que se maneja este buen oficial, repitiendo diarias pruebas de su actividad, conocimientos, y celo, con los varios apresamientos y represas que ha executado, siendo una de ellas la Embarcación en que hiba el citado Arraez, y aunque declarada por mi Tribunal de Guerra buena, y legitima Presa con su cargamento y distribuido el importe, según lo mandado por S. M., porque las partes consintieron la sentencia sin haber interpuesto apelación": Count de la Haye St. Hilaire to Mariano Luis de Urquijo, Campo de Gibraltar, 10 July 1800, AHN, Estado, leg. 5820.

34 Count de la Haye St. Hilaire to Mariano Luis de Urquijo, Campo de Gibraltar, 21 July 180o, AHN, Estado, leg. 5820 . Petition by Haslem el Rubio, Cádiz, 1 March 1797, AHN, Estado, leg. 5818. 
stated that the felucca was loaded with "dried beans, raisins, hides, bundles, and baggage that he loaded there for Tangier." The crewmen, four Moroccans and five Christians, were Juan Camina and Juan Pedro from Gibraltar, Juan González from Ayamonte, and Mallico and Juan García from Algeciras. Passengers were the "Hebrew" Sebastián Coto, the Genoese Miguel Supard, two Maltese named Miguel Pou and Juan Adán, Francisco Grimas from Gibraltar, and an Englishwoman, Anna Lee. Two of the Spanish sailors carried no passport. "The captain of the felucca submitted reluctantly and the Spaniards resisted," so all of them were placed under arrest. ${ }^{36}$

The felucca had been captured for sailing through enemy waters (the blockaded port of Gibraltar) and because its contract aroused suspicion, especially the plan to obtain new documents in Tangier and then return to Cádiz. The ship and its cargo of Moroccan products belonged to Caddur Ben Gileli of Tangier, and in the end was released while the Spanish crewmen remained in detention. ${ }^{37}$

\subsubsection{Absalem el Jedit (1798-18oo)}

In July 1798 supply launches from Santi Petri seized a ship flying the Moroccan flag "with a cargo of biscuit and 250 sheep. We will show the origin of this illicit commerce and who has been and is performing it." The Moroccan captain, Absalem el Jedit, went immediately to the Spanish consul general in Tangier, who was in Cádiz at the time, to declare that "although the load of sheep is in the name of another Moroccan, it is not true that he is the owner nor even that such a man exists, for even his name is false; and the animals belong to some Maltese from the Isla de León, who chartered the ship."

The consul took this as proof "that it was not Moors who were actually carrying out this trade, but certain Christians in their name." ${ }^{38}$ He thought that El Jedit was guilty of smuggling: "I consider him a criminal, but there is [the temptation of] excessive profits, these people's lack of knowledge, and the fact that our fellow citizens, during the entire blockade, have assumed their names in order to simulate ownership of their vessels, so in a way he may be forgiven." He recommended "setting them free with their ship, to avoid deceptions and so that [Muley] Soliman will not think we have seized it unjustly, on the pretext that he was bound for Gibraltar while his papers said the opposite." If the

36 Report by the commander of the Algeciras launches, 6 April 1797, AHN, Estado, leg. 5818.

37 Marquis of Roben to the Prince of Peace, Campo de Gibraltar, 10 April 1797, AHN, Estado, leg. 5818 .

38 J.M. González Salmón to Francisco de Saavedra, Secretary of State, Cádiz, 24 July 1798, AHN, Estado, leg. 5802 . 
Moroccans were pardoned they could be handed over "to the Moorish captain who comes to take command of the corvette, so he can take them both away" and bring them before the sultan; the ruler would then see "the generosity and impartiality" of the Spanish king. ${ }^{39}$

El Jedit's freedom did not dispose him more favorably to the Spanish authorities, for as soon as he arrived in Tangier he began to attack the Spanish justice system. Although he had been released,

he claims that the Spanish have used him ill, making him lose 3,159 reales that he had to pay in court costs; that many items were stolen out of his felucca; and that while giving testimony he was shut up in prison, when his only part in the offense was to have chartered the felucca. At the same time the Christians who were the true criminals and owners of the sheep were left unpunished.

The consul added that, although he was unfamiliar with the conduct of the case, El Jedit's version was biased: he had failed to state that two Maltese and a customs employee had also been detained, and that six more Moroccans were implicated in the affair:

Two Maltese were arrested as suspects; the action of this customs house had been circumvented, so one of its employees was also seized. Six open cases were discovered [supposedly] against Moors but actually against Maltese in this Health Office, as was later revealed; and other avenues were not pursued, to the detriment of discovering the truth. Finally, it seems that this affair has been covered up, since all involved have been freed; this makes me think that the Tribunal of Foreign Affairs or of War has been either very generous or dishonest. Otherwise it would be almost impossible that the true culprits, and others like them, would not be found, since it is well known that several previous attempts at apprehension have been made in cases where Moors had merely lent their names and their ship.

He asked to be sent "all the minutes of this case with all the other incidents that have resulted from it," so that he could study them and try

39 J.M.González Salmón to Francisco de Saavedra, Cádiz, 10 August 1798, AHN, Estado, leg. 5802 . 
to discover the offenders and impose the appropriate punishment, and with it put an end to excesses that are so scandalous and prejudicial to the State. And also so that the French may learn that the Spanish Cabinet will strive to end such abuses; for there are republicans who believe that they are tolerated and hidden, through a secret understanding between ourselves and the English. ${ }^{40}$

González Salmón also reproached the court for its slowness, leading him to speak to the city's governor,

to whom I confided what the Moor was claiming against us in Tangier, and how desirable it was to pursue the case with the greatest exactitude and promptness, because otherwise there could be unwelcome consequences. To this he replied that in any event the licenciate Don Luis Juan de León Sotelo, as assessor, would provide satisfactory answers to all of this, for the case had been handled very badly.

He claimed not to know enough jurisprudence to determine who was right, but was inclined to believe the licenciate ${ }^{41} \mathrm{He}$ reported that the governor of

40 "[H]a propalado, de que los Españoles solo havian usado de rigor con él, ocasionándole el quebranto de 3.159 reales que se le exigieron por costos Judiciales; que le han robado muchas cosas de su Falucho; y que durante las declaraciones ha estado en un encierro en Prisiones, quando no ha tenido mas parte en el delito que se le acumulaba, que el haver fletado su falucho; y que a los Cristianos, verdaderos reos, dueños del Ganado, los dejaron indemnes. ... [S]e arrestaron dos Malteses por sospechosos; que se justificó ser suplantado el Despacho de esta Aduana, de cuyas resultas se prendió también a un Dependiente de ella; que se delataron seis expedientes a nombre de Moros, pero de pertenencia a Malteses en la Oficina de esta Sanidad, que efectivamente se encontraron, y se omitió toda otra diligencia, en perjuicio de la averiguación de la verdad; y por ultimo parece que a este asunto se le ha echado tierra, pues se han puesto a todos en libertad, lo que me hace presumir de que por parte de este Juzgado de Extrangeria, ó Guerra, ha havido mucha condescendencia, y disimulo, por que de otra manera se hace poco menos que imposible se dejase de descubrir los verdaderos reos, y aun otros de la misma naturaleza, quando por notoriedad se save que anteriormente se han hecho varias expediciones iguales a la susodicha aprehensión sin tener los Moros en ellas mas que el prestar su nombre y Buque. ... descubrir los Reos para aplicarles el condigno castigo, a fin de cortar, con el escarmiento, excesos tan escandalosos y perjudiciales al Estado, y por otra parte para que conozcan los Franceses que el Gavinete Español zela, y procura, cortar tales abusos, pues hay Republicanos que creen que se toleran, y disimulan por inteligencia secreta que tenemos con los Yngleses": J.M. González Salmón to Francisco de Saavedra, Cádiz, 20 November 1798, No. 153. AHN, Estado, leg. 5802.

41 "[A] quien, confidencialmente, le insinue lo que dicho Moro propalaba contra Nosotros en Tanjer, y que convenia mucho se siguiese la causa con la mayor escrupulosidad y 
Tangier had made no official protest over the El Jedit affair, but had asked González Salmón in confidence if he were trying to discover the true story; on the latter's affirmative reply the governor had seemed satisfied. The government of Morocco was collaborating in the effort to end the practice of contraband, and he noted "the Moroccan government's willingness to prevent Moors from smuggling in our domains, nor shall any of their other abuses be tolerated. This makes it even more necessary that we try to discover the true offenders in the case of El Jedit and apply swift and merited punishment."

The consul also observed that El Jedit continued to request recompense for "the harm he received from his arrest in Cádiz": he presented to González Salmón a complaint against Juan Fita, a Maltese resident in Cádiz, who had appeared in Tangier to offer the Moroccan five hundred pesos fuertes "if he would say no more about the matter of the sheep." Fita fled to Gibraltar and then to Málaga, "for whose magistrate our consul gave the Moor Jedit a report or letter to the effect that he should aid in the arrest and detention of that Maltese, as long as Jedit identifies him and requests it."

González Salmón discovered that before the El Jedit incident two other Moroccan ships chartered by Fita and loaded with biscuit and sheep had sailed from Cádiz for Gibraltar, making it urgent to detain Fita "so that, once under arrest, he may reveal the true authors of this illicit, harmful, and scandalous trade." 42

Months later, the consul reminded the Secretary of State how important it was "in the service of the king" to inform the Moroccan government "about the complicity or indemnification of the Moors who claim to have joined in illicit commerce with the enemies of Spain: particularly the one named El Jadit [sic], who was apprehended with a cargo of sheep and biscuit on his way to Gibraltar."

He claimed to have documentary proof of the breadth of contraband activity involving the port of Gibraltar, in which even local institutions took part: "I have obtained certain documents that exist and are in my possession that, in my opinion, will reveal at the proper time not only the true offenders in this case but the intrigues with which [people] have tried and are still

prontitud, porque de lo contrario podía tener resultas poco gratas, a lo que me contexto diciendo; que en todo evento satisfará a ellas el Licenciado Dn. Luis Juan de Leon Sotelo como Asesor, por haverla dirigido pesimamente": J.M. González Salmón to Francisco de Saavedra, Cádiz, 11 December 1798, No. 163. AHN, Estado, leg. 5802.

42 J.M. González Salmón to Francisco de Saavedra, Tangier, 26 January 1799, AHN, Estado, leg. 5802 . 
trying to impede it." He alluded in particular to the "suit regarding fraud" brought against Licenciate Sotelo ("about which, I understand, testimony has already been sent to the Supreme Council of War") and against Bernardo de la Calle, Joaquín Zúñiga, and Francisco Sánchez. He advised that the documents he had collected "be reviewed and confirmed by the Admiral of this province, with absolute discretion and precautions, with those involved acknowledging their signatures"; thus once the Secretariat of State and the Supreme Council of War had been informed, "all these matters may be untangled, and an exemplary punishment meted out to the guilty to cut off at the root these scandalous abuses so prejudicial to the State." ${ }^{43}$ González Salmón argued that if a judge were sent to Cádiz to investigate the case "innocence will not suffer and malice will be punished, whoever the guilty party may be." 44

It is clear that Moroccans would scarcely have been able to indulge in smuggling in and out of Gibraltar without the complicity of Spanish merchants and bureaucrats, as well as other European traders settled in Cádiz and other port cities of Andalusia.

\subsubsection{Hamet Ford (El Sordo) (1798-1803)}

This was another case of contraband activity involving the introduction of foodstuffs and animals into Gibraltar. Its pivotal event was "the deliberate killing of the Moor Hamet el Sordo." "5 José Fabri, Manuel de Arriola, and Félix Gatt were accused of the crime and presented an appeal from their prison in Cádiz in 1803 . While not denying that the Moroccan had been killed in the room they shared, they attributed the crime to a plot: "On the morning of 26 July 1798 the body of the Moroccan Moor Hamet Ford was found in his own room, murdered by stabbing; and immediately the evil group of swindlers accused José Fabri of the murder." The object of the conspiracy was to hide the identity of the true culprits who were smuggling sheep into Gibraltar: "The swindlers had ascribed the exporting of sheep to the Moor Hamet Ford, who was unknown and ignorant of the plot. And this circumstance provided knowledge of

43 J.M. González Salmon to M.L. de Urquijo, Cádiz, 3 May 1799, AHN, Estado, leg. 4342.

44 The Secretariat of State sent Judge Francisco Pérez de Lerma to Cádiz with instructions to inform himself about the case against the adviser Luis Juan León Sotelo: two letters from J.M. González Salmón to M.L. de Urquijo on the same date, 7 June 1799. Francisco María de Peralta, in Luis Sotelo's name, sent him the statement of his defense: Madrid, 7 June 1799, AHN, Estado, leg. 4342.

45 A. González Salmón to J.M. González Salmón, Tangier, 2 August 1798, AHN, Estado, leg. 5802 . 
the iniquitous plan against the unhappy petitioners, who had heard about the Moor's death only from the public crier."

The imprisoned men claimed that the true perpetrators had convinced a prostitute to accuse Fabri of the murder, in exchange for a pardon in a criminal case of her own. We do not know how the affair ended, but it continued to appear in documents as late as $1816 .^{46}$

\subsubsection{Mahamet Chandri (1799)}

In 1799 the whole Spanish coast was warned that Mahamet Chandri, captain of the Moroccan mistico Embarek with six crewmen aboard, had left Cádiz bearing two patents, one dated October 3 for Tetouan and another dated later for Málaga. The captain had the "sinister intent" of proceeding to Málaga if he could not find someone to charter his ship in Tetouan. ${ }^{47}$

\subsubsection{Hamet Bohelen (1799)}

This "Moroccan Moor residing in Cádiz" declared in 1799 that he had "dealings and negotiations useful for commerce and advantageous to the nation." In a petition he complained of the poor cash flow he suffered as a result of the Spanish-English war and the English blockade of Spanish ports, and of the plague that Tangier was suffering that year:

Having established mutual dealings between this country [Spain] and his own [Morocco], throughout their ports as well as inland, he has both active and passive accounts with several individuals, as must occur in all trade. Timely remittances from his country, while his business was active, kept him prosperous and solvent until the unfortunate plague that ravaged Tangier for a time interrupted his receipt of any money or effects from that country, because of the well-founded legal prohibition imposed. At the present day this interception continues, although it is well known that Tangier enjoys the end of the ills that had assailed its inhabitants. This situation should be favorable to the petitioner, who needs to satisfy several debts that have fallen due but has no cash with which to do so.

46 Petition by José Fabri, Manuel de Arriola, and Félix Gatt, signed in the royal prison in Cádiz on 28 October 1803, AHN, Estado, leg. 5802 .

47 Notice issued by the kingdom's Supreme Board of Health through the Admiral of the Coast of Granada. Baron Serrahi to Board of Health, 23 October 1799; Pedro Molet to Board of Health, 24 October 1799, IM HB, FS, Serie I, leg. 21, fols. 138, 140. 
Hamet Bohelen was asking permission to bring gold and silver into Cádiz to resolve his difficulties. His father Hasib Bohelen, who was in Tangier, would send him

the sums of money he needs, which he has in his possession, so that the petitioner may satisfy his debts and continue his journey. He is prepared to pay both the royal duties and whatever may be incurred in the operation he is about to undertake. As a proper precaution, before the silver and gold is collected, he will infuse [his ship] with vinegar, aromatic spirits, fire, or whatever means found necessary to avoid contagion.

He was confident his appeal would be well received, especially "in the [present] critical situation in which cash is so scarce in this province and its commerce so decayed"; he would be able to send "the silver he needs for his payments from Tangier to Tarifa with the mail boat that arrives there from that port." In the end his request was granted. ${ }^{48}$

\subsubsection{Ataib (1799)}

This Moroccan captain often entered the port of Gibraltar, where in 1799, together with two other arraeces named Hamet Yngles Salazar and Alhach Malamud Almasaid, he acquired the polacre Massuba. Yngles Salazar eventually withdrew from the arrangement. The two-masted ship cost eight hundred pesos fuertes, plus an additional seven hundred to repair and restore it; of this

48 " $[\mathrm{T}]$ eniendo entabladas sus dobles negociaciones de este Pais para con el suyo en toda la extensión de sus Puertos y tierra firme ha venido á tener comprometidos de creditos activos y pasivos con varios Yndividuos como incidencia forsosa de todo trafico. Las remesas de su Pais a tiempo oportuno mientras estuvo corriente su comercio conservó aquel en su auge y exaltación hasta que la desgraciada peste que por algún tiempo ocupó a Tanger interrumpio el poder recibir del referido Pais cantidad alguna ni efectos, por la fundada prohibición legal que se puso sobre esto. En el dia ahunque continua esta interceptación es publico y notorio el beneficio que disfruta Tanger en la cesasion de los males que agobiaban a sus habitantes. Esta favorable incidencia en la situación del que expone de hallarse comprometido á satisfacción varios créditos de plazo cumplido sin tener efectivo con que hacerlo. ... las sumas de dinero que necesite y existen en su poder para satisfacer el Suplicante los créditos qe contra si tiene y continuar su giro, estando pronto á satisfacer tanto los Reales Derechos como lo que se cause en la operación á que esta pronto a sujetarse de que por justa precaucion se coloque antes de darse curso á la plata y oro que venga en infusión de vinagre espiritus aromaticos fuego ú en otros términos que se juzguen precisos para evitar el contagio": Petition signed in Arabic in Cádiz, 22 October 1799. On the favorable decision: Count of Cumbre Hermosa to Mariano Luis de Urquijo, Secretary of State, Cádiz, 19 November 1799. Gregorio de la Cuesta to Mariano Luis de Urquijo, Madrid, 5 November 1799, AHN, Estado, legs. 5809-5810. 
Ataib paid one-third, or five hundred, and became its captain. In the polacre's second voyage, under Captain Abdasalam Buasa, it was seized, as we shall see below. 49

\subsubsection{Alhach Malamud Almasaid (1799)}

We saw above how he became a co-owner of the polacre Massuba. After Yngles Salazar withdrew he assumed payment of one thousand pesos fuertes or twothirds of the total price. ${ }^{50}$

\subsubsection{Hamet Yngles Salazar (1799-180o)}

After the events recounted in the previous two sections, Yngles Salazar (who may have been a renegade) gave testimony in Málaga that the purchase of the ship had taken place. Stating that he was fifty-four years old, he was described as "a man dressed in Moorish costume who said he was named Arráez Hamet Yngles Salazar, captain of his Moroccan tartane Arbia anchored in this port. [He is] a native of Salé in the states of the Emperor of Morocco, who gave [his oath] by Allah the Great and his Prophet Mohammed, marking with his index finger according to the law and promising to tell the truth."

Yngles Salazar had, in fact, ceded his share in the polacre to his two partners at the time. He had done it because a chance had arisen to buy another vessel on his own: "I transferred my interest in the abovementioned [ship] to the said Captain Ataib and his partner Almasaid, those two becoming the only owners of the polacre. And there is no one else who owns any large or small share in it."51

\subsubsection{Hach Ali Elfucay (1799-18oo)}

Ali Elfucay of Tetouan, ${ }^{52}$ captain of the tartane Madruda, shipped a cargo of cinnamon and dried beans to Málaga and sold it to several merchants including José Antonio del Soto, "with whom he dealt, assigning him freely a large amount of cinnamon and dried beans at a price of fifty-two and a half reales per pound; this on the express condition that Soto would pay the petitioner the

49 Statement by Ataib and Alhach Malamud Almasaid, Málaga, 26 April 180o, AHN, Estado, leg. 5802. Also called Aljach Malamedid Almasaid.

50 Statement by Ataib and Alhach Malamud Almasaid, Málaga, 26 April 1800, AHN, Estado, leg. 5802 .

51 "In accordance with what he has declared, he has no doubt that there are no other owners of the polacre except the two named, who have assumed everything connected with its sailing”: statement by Hamet Yngles Salazar, Málaga, 26 April 180o, AHN, Estado, leg. 5802. He also appears as Hallach Ali Elfucai, Halhach Ali Elfucay, and Jach Aly el Fekei. 
full value of those goods in gold or silver coin, without any government bonds [vales reales]."

But "in spite of the [good] faith and legality" of the contract signed by both parties, and although other buyers had paid in cash, Soto tried to pay "with royal bonds the full price of the goods he had taken, which came to eighteen thousand seven hundred reales de vellón." Elfucay appealed to the governor of Málaga, who was the "Judge Protector" of the bonds (Juez Protector de los Vales Reales), explaining to him "the very grave disadvantage that he would certainly suffer with a payment in that form. Because in spite of your fairness and generosity, bonds in that city usually lose forty-five percent; and the contract with Soto had been for cash to the total exclusion of bonds." He argued further that the paper was valueless and useless in Tetouan. But the governor, applying strictly the royal decree about the matter, declared that Soto could legally pay in bonds, which Elfucay must accept "with a discount of six percent" (i.e., subtracting six percent of their face value). The Moroccan then appealed to "the great goodness" of the king, hoping he would understand that "the petitioner is not established in these kingdoms but only visits them, and comes to the port of Málaga to sell and dispatch the goods of his trade." If forced to accept bonds "the petitioner would be reduced to the utmost infelicity and poverty," for "he has no other means of subsistence than modest traffic and dealing in his merchandise" and the losses he suffered by using bonds were "constant." He was sure that the king did not intend foreigners to be recipients of such payments, and repeated that he was "a person in transit, now in debt to Your Majesty's goodness if he is to be ruined by the need to accept the bonds." He begged that Málaga's governor be ordered to make Soto pay "the full value of the goods sold in cash, in gold or silver coin and not in bonds, according to what is stipulated," and compensate him "for all the harm and damage done to him by [Soto's] slowness, delay, and resistance to adhering fully and truly to the contract." If that were not to be, he asked to have the goods that had been sold returned to him from their warehouse. ${ }^{53}$

Three days later Elfucay petitioned again with the same arguments but at greater length. He claimed that as he and Soto had negotiated for the sale of his goods, valued at eighteen thousand reales, the Spaniard had wanted to pay in bonds but he had refused them: "I know nothing of bonds and the deal had to be made in cash." Elfucay claimed that the governor, after hearing him, had told him that there was deception but that he could not satisfy him; Elfucay should have his goods stored and then appeal to a higher court. According to 
the governor, other merchants in Málaga were prepared to buy his goods at 104 reales the pound in bonds, but the Moroccan refused again: "I did not wish to sell, but only so as to receive cash I sold them for half the amount that those men were offering me, for I know nothing of bonds nor are they used in my country." He felt defrauded by Soto, and continued to press for either payment in cash or the return of his merchandise..$^{54}$

Antonio González Salmón, Spain's vice consul in Tangier, was asked for his opinion, and thought "at first glance" that if Elfucay were made to accept bonds it would cause him "a notable loss" in his business dealings in Spain. He advised keeping this in mind so as "to avoid claims by the Moroccan government in matters of this kind, which would oblige His Majesty to decide that he must be paid in cash." But acceding to the Moroccan's petition would inspire other foreign merchants to demand the same treatment, "causing disputes over relief of damages such as the petitioner claims." The vice consul knew that paper money was "discredited ... but every good vassal should try to support it." He therefore approved of returning the cinnamon and beans to Elfucay, since he was "willing to receive them," and annulling the contract of sale if it could not be made in cash. "This decision by the sovereign will allow a purchaser to keep the goods if he is willing to pay in silver or gold coin." ${ }^{55}$ The Secretariat of State agreed, noting on the cover of the file: "If [Soto] does not wish to pay him in cash, let his cargo be returned." 56

At this point the Judge Protector of the bonds, who was also the governor, affirmed that the contract in question did not exclude payment in that form, "for the Moors pay their customs duties in it, and foreigners who conduct business in this country are not exempt from the royal decree of 17 July 1799 that orders bonds to be accepted like money in cash, without any deduction, or if there should be any, of only six percent." That was why he had made Elfucay accept bonds reduced by six percent for his goods, and the Moroccan had not appealed the judgment in time or in the proper form. The governor was annoyed that Elfucay had gone "directly to you and obtained a royal decree favorable to

54 Petition of 27 December 1799, Madrid, also signed in Arabic. An accompanying note registers the petitioner's complaint that the governor of Málaga had not offered him justice: AHN, Estado, legs. 5809-5810.

55 A. González Salmón to Mariano Luis de Urquijo, Tarifa, 8 January 1800, AHN, Estado, legs. 5809-5810.

56 Málaga's governor told the Secretariat of State that he had received the royal order for "the Moor Halhach El Fucai to be paid in coin for the cinnamon and dried beans that he sold to J.A. de Soto; otherwise let the goods be returned to him": Pedro Truxillo to Mariano Luis de Urquijo, Málaga, 11 January 180o. The cover note is dated 16 January 180o, AHN, Estado, legs. 5809-5810. 
him, after the governor of Málaga had collected statements against Soto, putting him under embargo and threatening him with prison." 57

Not surprisingly, J.A. Soto immediately appealed to the Judge Protector against the governor's decision "on the Moor Argas Aili [sic] regarding payment for a portion of cinnamon and beans." He argued, cleverly, that the action discredited the royal bonds and, in practice, violated the royal decree of the year before. ${ }^{58}$

A few days later, Soto submitted a petition in which he acknowledged having "bought from a Moroccan Moor named Argach a portion of cinnamon and beans without specifying if the payment was to be in bonds or in coin, only that the full sum was to be paid." He added that the seller had rejected his bonds. The result was a hearing in which the governor, in his capacity as Judge Protector of Bonds and supported by his accountant, decided that the Moor should accept "payment in bonds with a discount of six percent, in observance of your royal decree of last 17 July and later declarations, by which paper money has all the value of minted coin except for the six percent in certain designated cases."

The Moroccan did not appeal the sentence, and once the time allowed had run out it "became irrevocable and was executed as the laws of the kingdom establish." It is interesting to note that Soto then claimed that Elfucay had acted "clandestinely" by going through the Secretariat of State to the king, something that had negative consequences for himself:

He obtained a royal order through the obvious vices of misrepresentation and surreptitiousness: Your Majesty ordered that, since the Moor's account was true, the governor should make me pay him in coin. This royal order was properly obeyed, and in order to do so this petitioner was given three days to establish if the Moor's story was true or not; but within this time, and without the petitioner being allowed to take statements and verify them, because the Moor had presented a document with witnesses who claimed that they had bought cinnamon from him in cash for the same price and if paid in bonds it would have cost much more, the governor ruled verbally and without hearing this petitioner that he [Soto] should pay the money immediately. And when he did not do so because

57 Report by the Judge Protector of Royal Coupons, Málaga, 14 January 1800, AHN, Estado, legs. 5809-5810.

58 J.A. de Soto to Juez Protector de los Vales Reales, Málaga, 15 January 1800, AHN, Estado, legs. 5809-5810. The bonds had initially been issued in 1780 . 
he had not received another [sum] owed to him from the beginning in bonds, his goods were embargoed. And the governor, not satisfied with this pressure, half an hour later through an assistant warned him to hand over the money, otherwise he would put him in jail.

Soto called these events "a series of violent acts contrary to the system that the sovereign authority of Your Majesty has established in the courts of justice." His appeals to the courts had not led to any "success in his legal claims, and he has reason to fear that after causing him all this considerable vexation [the courts] will harm his person, contrary to what Your Majesty has disposed: that one may not imprison for civil debt not only a distinguished man like the petitioner but even an artisan."

For all these reasons Soto was appealing to the monarch to denounce the dual strategy of Moroccans vis-à-vis the government bonds, which agreed with what the Judge Protector had decided: "These same Moors who now pretend to annul, for their purposes, the General Royal Decree of 17 July that Your Majesty recommends so strongly, are the same ones who take advantage of it to pay royal customs duties and any other payment that occurs to them."

Soto ended by begging the monarch to issue another decree, suspending everything decided in this case "subsequent to the sentence, and to return to the original reports." The king should resolve the case after having seen all its documentation. The consulate remained in possession of four government bonds of three hundred pesos, and "in view of the fact that the abovementioned goods were seized and the goods of J.A. Soto were embargoed, the consulate awaits further instructions in the matter." We do not know the final result of the case. ${ }^{59}$

59 "[Y] ganó una Real orden con los vicios visibles de obrrecion y subrrepcion, en que V. M. se dignó mandar que siendo cierto el relato del Moro hiciese dicho Gobernador que yo le pagase en dinero metalico, cuya Real orden se obedeció como es debido, y para cumplirla se dio traslado al exponente por tercero dia para venir en conocimiento de si el relato del moro era, ó no cierto; pero pendiente el traslado, y sin dejar al exponente qe tomase los autos para evaqüarlos, á motivo de haver presentado el Moro un escrito con unos testigos que dijeron haverle comprado canela por dinero metalico al mismo precio, y que a Vales había sido a mayor, mandó el Govor. Verbalmente y sin oir al que expone, que este pagase en dinero inmediatamente, y no habiéndolo ejecutado pr carecer de otro qe el que tenia consignado desde el principio en Vales se le embargaron sus bienes, y no contento el Govor con este apremio le intimó a la media hora por medio de un Ayundante que diese el dinero, y que de lo contrario lo pondría en la Carcel": Petition by José Antonio de Soto, Málaga, 18 January 1800, AHN, Estado, legs. 5809-5810. 


\subsubsection{Caddur Ben Gileli (1799-1804)}

One of the merchants most active in trade with Spain was Caddur Ben Gileli60 of Tetouan, nicknamed "Patagorda." He owned the Moroccan mistico Embarck, which was seized in 1799 by the Spanish garrison at La Atunara near Gibraltar as it was heading for the English port with thirty-seven cows on board. Its captain, the twenty-four-year-old Jamet Megan, claimed that it was his first voyage in the mistico, the property "of a Moor named Patagorda from Tangier," and that he was to sell the cattle "wherever he could." The crew members were two Moroccans, two Portuguese, and five sailors from Gibraltar who had already been working the ship when the captain took it over; but its health certificate listed only six crewmen. Megan insisted that "the scribe must have been stupid" when he made out the patent, and that he knew nothing about it. The crew, on being questioned, claimed ignorance of the ship's destination and had only heard that the vessel and the cattle belonged to "a Moor they call Patagorda."

The commander of the forces that took the mistico insisted that the ship had infringed Article 33 of the corsair rules by trying to bring food into a blockaded port, a clear case of smuggling. The ship's papers at the moment of seizure were thrown into the sea, and the few that survived agreed neither on the name of the captain (a certain Mesod was mentioned) nor on the makeup of the crew. The officer accused Gileli beside of being "a straw man, because the true owner is Josef Aburbe, a resident of Gibraltar." The mistico was thus declared a legitimate prize.

The Spanish consul in Tangier was instructed to notify Gileli "Patagorda" to appear "in person or through a representative to demonstrate his rights within a period of fifty days." After ten additional days had passed, the status of the mistico as a prize was affirmed. ${ }^{61}$

It was later learned that Gileli had bought the vessel at public auction in Gibraltar. It had belonged to Alonso de Casas, a scribe from Estepona, and sailed with Moroccan papers so as to elude English corsairs and warships, but had been captured by the English in 1797 and taken as a prize to Gibraltar. On the Spanish side doubt arose as to whether, even though the capture obeyed corsair regulations, Gileli should be refunded the price he had paid at auction "as a gesture to his sovereign and his flag." But the Minister of the Navy thought that the ship might still belong to the English and be sailing with false papers: "just

6o He is also called Ben Chilelli, Ben Chileli and Ben Shilely.

61 Report bearing no names but undoubtedly addressed to the military governor of the Campo de San Roque, dated 24 March 1801. Aranjuez to the Ministry of War, 24 March 1801, AHN, Estado, leg. 5807. 
as before it concealed a Spanish [owner], now it may do the same for an English one in order to trade with impunity." He maintained, in any event, that under Article 19 of the Peace Treaty of 1799 regarding neutral nations, both the ship and its cargo constituted a legitimate prize. ${ }^{62}$

Gileli offered a fine example of persistence in petitioning the Spanish king and the Secretary of State: he sent them at least three petitions between July and December 1804, laying out his case and demanding to be heard. ${ }^{63}$ In July he wrote that he had been conducting trade between Spain and Morocco "for the last thirty years ... with all the coasts of Spain reached by his ships and merchandise." As a result he had earned a good reputation: "Through the legality and good faith of his dealings he has earned the [good] opinion and esteem not only of the important persons in the towns where he went with his goods but from their chiefs and commanders." His specific references, however, were all to 1797, in the midst of Spain's war with England. At that point Alfonso García, supply officer of the Campo de San Roque, arrived in Tangier intending "to purchase oxen for the sustenance of Your Majesty's troops that were then in that region." He carried a letter from his superior to the Spanish consul in Tangier, who asked Caddur Ben Gileli to deal with García "without any concern for collecting the purchase price of the cattle he sold." Armed with this guarantee, Caddur had "agreed with García to sell him 168 oxen at 27 and a half duros apiece, on the explicit condition that their shipment to Spain should be at the Moor's own risk; and as he sold them the money should be given to him, with the necessary permission to take it to his country."64

Caddur made four crossings to Spain as he kept his part of the bargain, but García paid him only in part: "He paid the ships' captains for the charters, and also another sum for the purchase with a letter of credit issued by Don Antonio Boolmo, to be paid by Don Manuel de Aragón, a resident of Ceuta." Caddur began to be suspicious of García: "Many months had passed and he did not

62 Juan Pérez Villaamil, Minister of the Navy, to Pedro Ceballos, Madrid, 21 March 1801. Throughout the year 1800 there was pressure "by interested persons" on the parties involved in the capture, claiming shares in the ship's auction price and its cargo. In the documents are José Joaquín Delgado, 2 October 180o; Antonio Cornell to Mariano Luis de Urquijo, 29 May, 16 October, and 3 December 18oo; Count de la Haye-St. Hilaire to Antonio Cornell, 17 November 18oo; José Antonio Caballero to Pedro Ceballos, 12 March 1801, AHN, Estado, leg. 5807 .

63 We know of the August petition, the first, only through references to it in the one sent in November.

64 Petition dated in San Lorenzo del Escorial on 29 July 1804. A note at the end specified that it had been presented with a power of attorney signed by Antonio Lozano y Anaya, AHN, Estado, leg. 5804 . 
produce the rest of what he owed, claiming that he had not received permission from Madrid to take the money [out of the country]." Caddur complained to the consul, who appealed to the military governor of the Campo de San Roque, and that official put García in jail:

García was arrested, an accusation was drawn up against him, and they confiscated some money he had in Seville that came from the sale of those same oxen. [But Caddur] was not able to recover the entire debt because the unfortunate, unhappy supplier died right there in the Campo de San Roque in poverty, leaving no property whatsoever. Nor was [Caddur] able to persuade the leadership of San Roque to investigate whose straw man, or mere instrument, García had been; he asked, and asked again, in many petitions sent through the consul general. Therefore the Moor Caddur, aside from the serious damages and costs he has incurred, must now satisfy the contract for forty reales de vellón. ${ }^{65}$

Caddur also recalled the assistance he had given during the epidemics of yellow fever on the Andalusian coast, especially in Cádiz and Málaga, in the early years of the century. He claimed to have sailed to Tarifa more than eighty times:

While the epidemic was being endured in Andalusia no boats could be found to carry correspondence from one nation to the other. And the Moor Caddur, at only the slightlest suggestion by the consul general, offered the best and fastest sailing ship he had and loaned it with the greatest pleasure, so that it could perform a service so interesting to His Majesty.

And not only that: thirteen deserters from Ceuta had stolen his ship, which he recovered only a year and a half later in Marbella:

65 "[S]e puso preso al García, se le formó causa, se le embargó una partida de dinero existente en Sevilla procedente de la venta de los mismos Bueyes, [pero Caddur] no pudo cobrar el todo de la deuda, pues el vivandero murió en el mismo Campo de San roque desdichado miserable é infeliz, sin dejar bienes algunos, y no pudo tampoco lograr que con la Comandancia General de San Roque se procediese á la averiguación de los sujetos de quienes parecia haver sido Garcia un testaferro, ó un mero instrumento lo qual, pidió, encargó y reencargó por repetidos oficios que pasó a ella el citado Consul general, de manera que el Moro Caddor, además de los graves perjuicios y costos que ha sufrido, se le ha quedado en deber de aquella contrata la cantidad de 40 rs. vn.": Petition dated in San Lorenzo de El Escorial on 29 July 1804, AHN, Estado, leg. 5804. 
And after having made more than eighty trips carrying correspondence from Tarifa to Tangier, in the latter port one night when he had scarcely arrived [his ship] was stolen by thirteen Spaniards who came from the fortress of Ceuta. Your consul general therefore sent inquiries along the entire coast of Spain and after sixteen months it was found in the port of Marbella wholly destroyed; in order to make it seaworthy the petitioner was forced to spend more than ten [thousand] reales and suffer the harm of having no use of the ship for a period of time. For after the robbery it was found to be damaged and useless for most voyages.

He had suffered other serious losses in the preceding years through "the lack of good faith in the way several Spaniards have managed their contracts, failing utterly to fulfill them, so that he has been unable to collect anything from them." 66

Finally, he admitted to having smuggled goods in the port of Gibraltar, although, he claimed, before the imposition of the blockade. He therefore demanded the return of a ship of his that had been seized on its way there with a cargo of oxen, "about which there is a current lawsuit in your Council of War." 67 He had lost ninety thousand reales de vellón and fallen into financial ruin:

All these losses and setbacks, Sir, have reduced the Moor Caddur to a deplorable situation, after he had served Your Majesty and the king of Morocco for thirty years with honor, impartiality, and zeal. So it can truly be said that his house has been ruined, when it was once one of the richest in the kingdom. These facts are known not only to your consul general

66 "[E]n el tiempo que se padecía la epidemia en Andalucia, no se encontraron Barcos que llevasen la correspondencia de una á otra potencia y el Moro Caddor con solo una lebe insinuación del Consul general aprontó el mejor y mas velero que tenia y lo cedió gustosísimo, para que hiciese un servicio tan interesante a S. M. ... [Y] después de haver hecho mas de ochenta viajes llebando la correspondencia desde Tarifa á Tanger, en este Puerto una noche en que apenas acababa de llegar lo rovaron trece personas Españolas, que se pasaron desde el presidio de Ceuta, con cuyo motivo vuestro Consul general libró requisitoria á toda la costa de España, y después de 16 meses se encontró en el Puerto de Marvella todo destrozado y en termino que para ponerlo en disposición de navegar, tubo el exponente que gastar pasados 10 [mil] reales y sufrir el perjuicio de carecer algún tiempo del uso de este este buque, que siendo al tiempo del rovo, se halló después remendado e inútil para hacer muchos viajes": Petition dated in San Lorenzo de El Escorial on 29 July 1804, AHN, Estado, leg. 5804 .

67 In 1797 launches from Algeciras had captured the felucca $E l$ Sid or Sahin under Captain Haslem el Rubio as it was leaving Gibraltar: this is undoubtedly the ship owned by Gileli to which he refers. See above section 9.4.2. 
in Morocco but are public and notorious. Therefore, making a reasonable calculation of the losses experienced by the Moor Caddur in recent times, they come without doubt to the sum of ninety [thousand] reales de vellón.

To recover financially and continue "in the service of Your Majesty and the king of Morocco,"68 he requested permission to bring into Spain six hundred quintales of wax, free of customs duties: "In this way he will not only achieve his purpose but also save his family, which has been reduced to an unhappy state by so many misfortunes." 69

In September 1804 Antonio González Salmón, Spain's consul in Tangier, wrote to the Secretary of State asserting the truth of Gileli's claim, except that Alonso García had appeared in Tangier not with a recommendation from the military governor of the Campo de San Roque but with "a passport that authorized and approved the object of his journey here to buy oxen." That passport was invalid because at the time the exclusive privilege of importing cattle belonged to the Five Guilds of Madrid. The consul, however, "wishing that region [Campo de San Roque] to be supplied without violating the said privilege, suggested that the Moor sell the cattle on board in the bay of Algeciras itself, and he did so." Alonso García, he explained, "was a mere straw man." When the ships from San Roque had seized Gileli's vessel, the sultan had not yet been informed that the port was under blockade by Spanish troops, and in this the Moroccan was in the right. He also confirmed that deserters from Ceuta had stolen Gileli's ship in their escape from Tangier and had damaged it. ${ }^{70}$

The Minister of the Treasury acknowledged that Gileli "had been employed for many years in commerce among various ports of our Peninsula, supplying their inhabitants with meat and legumes"; also that he had arranged a

68 Also, "so that his business may prosper in some manner and he may again be useful to the State": petition by Caddur, Madrid, 15 November 1804, AHN, Estado, leg. 5804.

69 "Todas estas pérdidas y quebrantos señor han reducido al Moro Caddor á una situación deplorable después de haver servido treinta años a V.M. y al Rey de Marruecos, con honor, desinteres y zelo, de forma que se puede decir, en verdad que ha quedado casi arruinada su casa siendo antes de las mas opulentas de su Reyno; cuyos estremos no solo constan por menos a vuestro Consul General de Marruecos, sino que son públicos y notorios: de manera que formando un calculo prudente de las perdidas que ha experimentado el Moro Caddor en estos últimos tiempos ascienden sin duda á la cantidad de go [mil] rs. de vn. ... [D] e este modo conseguirá no solo el fin que lleba propuesto, sino el de conservar su familia que se be reducida con tantos quebrantos á un estado infeliz": petition by Caddur, Madrid, 15 November 1804, AHN, Estado, leg. 5804.

70 Antonio González Salmón to Pedro Ceballos, Tangier, 10 September 1804, AHN, Estado, leg. 5804 . 
purchase of oxen with Alonso García in 1797 and had fulfilled the terms of the contract while García had failed to pay him, "for which reason he was arrested and sentenced to fulfill what he had promised. But since he died in that period and left no funds, the Moor was left much harmed in his interests after he had pledged to supply the Campo de San Roque." Gileli had placed his ships at the disposal of the Spanish consul "as long as he employed them for his ordinary and extraordinary journeys." The minister knew that several Spaniards with whom the Moroccan had dealt had failed "in what is required of good faith by a contract, so that he has had very large losses and is now reduced to penury." He was aware of the theft and near-spoiling of one of Gileli's ships. Therefore he asked that the Moroccan be compensated "in some measure" by a permission to import the abovementioned large quantity of wax, free of customs duties. Once his prosperity returned he could once again supply Spanish ports in time of need, as he had done in the past. The minister wished the king to be informed of the case because the petitioner's claims appeared confirmed by the consul in Tangier, who "believes him deserving of some compensation." ${ }^{71}$

In a subsequent report, however, the minister retracted what he had argued before, alluding to a royal decree of 24 June 1804 that forbade the importation "in the future of any goods brought by the Moroccan Moor Caddor Ben Gileli." The king, after reviewing Gileli's arguments, had decided not to admit his petitions: "If this Moor performed some service he must have been paid, or have gone to someone who gave him a loan for his satisfaction and payment. He and other foreigners and Spaniards should not believe that they can solicit such permissions that are damaging to commerce."72

Caddur persisted, with a new petition in mid-November "that spoke at greater extent of the affair and other matters." He repeated that he had signed the contract with Alonso García "urged and encouraged by your consul general in Morocco," and "authorized by a letter from the military governor of the Campo [de San Roque]." The Secretary of State passed the petition on to the Minister of the Treasury, who declined to act and returned it: the king had suspended "all favors for imports free of duties in his kingdom, so [Caddur] should approach the [Secretary of] State, who should pay him, assuming that he had approved his venture."

71 Note from Miguel Cayetano Soler to the Secretary of State, San Lorenzo de El Escorial, 27 October 1804, AHN, Estado, leg. 5804.

72 Miguel Cayetano Soler to Pedro Ceballos, San Lorenzo de El Escorial, 8 November 1804, AHN, Estado, leg. 5804. 


\section{Caddur insisted that}

He asks for no favor, considered as a favor, but that the amount left owing to him from that contract be restored in some way: it is forty [thousand] reales de vellón together with other losses caused him by the Spanish, as he has explained in his statement, and it all comes to ninety [thousand] reales.

He repeated his request to import the six hundred quintales of wax free of customs duties. He also complained of "the increased sums demanded of him for his petition to recover his patrimony in the space of six months," and asked to be "granted some permission that will let him be paid what he is owed." ${ }^{73} \mathrm{~A}$ few days later he penned a new appeal, this time from San Lorenzo de El Escorial. Once again he lamented that Alonso García had not paid him in full, and demanded some solution that would help him, "since he is required to return to his country, and has no means of verification because of his increased expenses during the six months he has spent away from home." He begged for attention to his cause so that he could begin his journey and "recover, by this means, the harms and damages to him," especially after royal favor had been denied (he did now accept that it would have been a special favor). The Secretariat of State once again responded that he was owed nothing, and a note on his petition instructed: "Let him be told that the king bears no responsibility at all for restoring the damages he claims, on the basis of the reasons and arguments that the petitioner presents." ${ }^{74}$ Gileli received only a single concession, much smaller than what he was requesting. It was noted on his petition: "Out of consideration he was granted one thousand five hundred pesos fuertes for him to return to his country, by verbal order of His Excellency regarding expenses of the Secretariat."75

\subsubsection{Mohamet Valenciano (180o)}

Captain Mohamet Valenciano was one of many frequenters of Spanish ports. He was therefore subject to the sultan's order of late 1799 for Moroccan-flagged ships to leave Europe and return with empty holds to their country, where they

73 " $[\mathrm{N}]$ o pide gracia alguna, considerada como gracia, sino que se le resarza de algún modo, la cantidad que se le quedó a deber de aquella contrata que es 40 [mil] reales de vellón y además otras perdidas, que le han causado los españoles, como expone en la dicha representación, y que todo ello asciende a 90 [mil] reales." A marginal note reads, "Nothing is owed to him": petition by Ben Gileli, Madrid, 15 November 1804, AHN, Estado, leg. 5804.

74 Petition by Ben Gileli, San Lorenzo de El Escorial, 15 November 1804, AHN, Estado, leg. 5804 .

File of Ben Gileli, AHN, Estado, leg. 5804. 
would be limited to coastal trade; the ruler had also asked European countries not to allow his ships to load and unload in their ports. Valenciano, then in Málaga, complained to the king of Spain "in his own name and that of others whose ships were detained in Málaga, that Spanish port authorities were forbidding him and other Moroccan captains to load and unload in the ports where they found themselves." He argued that they had "brought authorized goods from Faro, with their papers in order." While not intending to violate the sultan's order, they hoped to take advantage of the six-month grace period; but that had already elapsed, and examination of the ships' papers provoked serious doubts about their legality and that of their cargoes. The king of Spain knew that he had to accept the sultan's decision and that the grace period was over, but hoped to avoid "the harm to be incurred by these individuals if they cannot sell their products in Spain," again invoking "the good harmony that reigns between this Court and that of Morocco." He therefore decided that all ships currently in that situation in Spain

may have permission to unload and sell their goods, and then at once be obliged to leave for their country with only ballast, if their ships are truly Moroccan. And if they are not, let their papers be collected and their crews required to return to their countries aboard other ships, which are to be left at the disposal of their true owners so long as they are not enemies of His Majesty. If they are they will be confiscated, for all this agrees with the spirit of Muley Soliman's decree, which all his subjects must obey. ${ }^{76}$

\subsubsection{Haljach Abdalá (180o)}

This captain gave testimony in Málaga in the case of the polacre Massuba, sold to the Moroccans Ataib and Alhach Malamud Almasaid in Gibraltar in 1799, as we saw above. He was described as "a man dressed in Moorish garb, who ... said he was called Arráez Aljach Abdalá, captain of the Moroccan goulette Maimuna now anchored in this port; a native of Salé in the states of the Emperor of Morocco, who [swore] by Allah the Great and his Prophet Mohammed,

$76 \quad$ “...descarguen y vendan sus efectos siendo permitidos, y seguidamente se les obligue á salir en lastre directamente para su país, siendo sus buques realmente Marroquíes; y no lo siendo se le recojan los papeles y se obligue à las tripulaciones à bolver a sus país[es] à bordo de otros buques, quedando estos a disposición de sus verdaderos propietarios, como no sean enemigos de S.M., en cuyo caso quedarán los cascos confiscados, pues todo esto es conforme al espíritu de la órden de Muley Soliman, que todos sus súbditos deben obedecer": Semanario Económico, 9 August 1800. 
indicating with his index finger as is proper and promising to tell the truth." Abdalá said that he was thirty-five years old and signed his statement in Arabic. He frequented the port of Málaga around $1800 .{ }^{77}$

\subsubsection{Haljach Candur (180o)}

He was another witness in the case heard in Málaga: "a man dressed in Moorish garb, who ... said he was called Arráez Haljach Candur, captain of the Moroccan mistico Larnib anchored in this port, a native of Larache." He was twentyfour years old and also frequented the port of Málaga. ${ }^{78}$

\subsubsection{Algache Abdarrajaman Acatam (180o)}

This "Moorish Moroccan merchant" petitioned the Secretary of State in 1800 to be allowed to bring a cargo of cinnamon into Spain; it had been forbidden in November 1799. In a petition of May 1800 in which he mentioned an earlier one of 18 April, he explained:

He is now in Spain in the port of Málaga, dealing and trading and contributing considerable duties to the Royal Treasury. And he asked Your Majesty to grant him the favor of allowing him free entry and the sale of eighteen sacks of cinnamon; for when Your Majesty's royal order forbidding the entry of cinnamon was issued the ship had already left the port of Faro in the Kingdom of Portugal, and Your Majesty's royal goodness should generously grant his request.

He added that he also wished "to sell six bundles of cinnamon that arrived after the [other] two ships"; these were stored in the customs house in Málaga. If he received permission it would be "sufficient satisfaction for the damages and expenses he has been caused."79

77 He testified before the judge advocate of the tribunal in Málaga with other witnesses: AHN, Estado, leg. 5802 .

78 He testified before the judge advocate of the tribunal in Málaga with other witnesses: AHN, Estado, leg. 5802.

79 "[S]e halla en España y Puerto de Malaga, traficando y comerciando contribuyendo al Real Erario, considerables derechos, y pidió a V. M. le concediese la gracia de permitirle la libre introducción y despacho de 18 churlas de Canela, respecto a que quando se expidió la Real Orden de V. M. proiviendo la entrada de Canela, ya había salido el Barco del Puerto de Faro reino de Portugal, y la Real bondad de V. M. ha tenido a bien concederle su solicitud": Petition dated May 1800 and signed in Arabic. It requested a report by Miguel Cayetano Soler, Minister of the Treasury: AHN, Estado, 5802. 
The Secretary of the Navy had to give his opinion, and decided that "If he ordered [the merchandise] before the issuance and publication of the royal decree of 23 November of last year, and has not had enough time to suspend his order, I believe he should be allowed to introduce it and sell it in the kingdom with the corresponding payment of royal duties." He noted that many other merchants from different countries found themselves in similar straits and should be allowed to do the same..$^{80}$

\subsubsection{Hamet Bujalel (180o)}

We know little about him except that in 1800 he filed a complaint against Luis Quintana, a merchant from Cádiz who had failed to honor a contract signed by them both. ${ }^{81}$

\subsubsection{Abdasalem Buasa (18oo)}

The Moroccan felucca Masud under Captain Abdasalem Buasa was captured off the beach of La Atunara in La Línea de la Concepción in August 180o. It had sailed from Almería for either Algeciras or Cádiz, as Buasa reported:

In the port of Almería it loaded esparto grass, forty arrobas of tallow candles, twenty quintales of biscuit, ten quintales of flour for making couscous, and three hundred dozen eggs. It obtained in Almería the required passport for Algeciras, and if [the goods] could not be sold there, for the port of Cádiz to make the sale.

After a layover in Málaga it was pursued by three corsair feluccas under the military governor at San Roque, whom Buasa accused of having armed the ships privately. He never expected to have problems after loading in Almería and paying the necessary duties, and "in all modesty" thought it unjust that

he be attacked in this way: they collected his passport from his Emperor and 262 duros he carried for his unavoidable expenses and made him a prisoner, not in some enemy territory but on the coast of Spain with his ship and all his cargo. They pointed pistols and swords at the breast of the petitioner and all his crew saying "Silence, dogs!" and other such ugly words. They spat on the Moroccan flag, contrary to the orders Your

8o M.C. Soler to M.L. de Urquijo, Aranjuez, 12 May 180o. Aranjuez to M.C. Soler, 17 May 1800. The king assented: AHN, Estado, leg. 5802.

81 Only the cover of the the empty file survives: AHN, Estado, legs. 5809-5810. 
Majesty must have issued and that they should obey. Therefore irreparable harm has been and is still done to him.

He demanded the return of his ship and cargo, his passport from the sultan, and his 262 pesos, otherwise "he will be entirely ruined, for he is in the most pitiable situation with nothing to eat; therefore he begs for [the king's] protection." 82 The appeal led the Secretariat of State to request information from the military governor of the Campo de Gibraltar about Buasa, "his ship having been improperly seized on its way from Málaga to Algeciras," 83 but the local military court ruled against the Moroccan and proceeded to distribute his goods among his capturers. ${ }^{84}$ Buasa made new appeals in August and October $1800,{ }^{85}$ but was not able to reverse the earlier judgment: "This has already been denied by virtue of the report by the military governor of the Campo de San Roque dated 13 October 1800." 86

Buasa made a fresh attempt in March 1801 with another petition that contained few new arguments. He noted that he had "a fair amount" of esparto grass and was authorized to sell it in Algeciras, but if he found no buyers there he could go on to Cádiz. He claimed that the three corsair vessels that had captured him "had violated the Peace Treaty of March 1799." The attackers had taken over the ship "seizing violently his passport from the Emperor and 262 duros he carried for his expenses, thrusting pistols and swords at his breast, shouting many insults, and making other supremely rude gestures that cannot

82 "[E]n el Puerto de Almeria cargó esparto, quarenta arrobas de Belas de sebo, veinte quintales de Biscochos, diez quintales de Arina para hacer alcuscus, y trescientas docenas de huevos, para cuyo transporte sacó de Almeria el correspondiente Pasaporte para Algeciras, y si en esta no tubiese despacho poder pasar al Puerto de Cadiz á hacer su benta. ... que se le atropelle de esta forma, haviendole recogido el Pasaporte de su Emperador, doscientos sesenta y dos duros que tenia para sus indispensables gastos, traiendole apresado, no en parte sospechosa, sino en la costa de España, Barco y todo el cargamento poniéndole asi al que expone como a la Tripulacion, las Pistolas y Espadas a los Pechos espresando Callar Perros, y otras malsonantes. Escupiendo al Pavellon Marroqui, lo que es impropio á las ordenes que deven observar y V. M. tendrá expedidas por tanto y para precaver los irreparables perjuicios que se le an irrogado e irrogan": Petition by Abdasalem Buasa, 9 August 1800, in which he refers to a previous one of July of that year. There is also a petition written entirely in Arabic, AHN, Estado, leg. 5802.

83 San Ildefonso to the military governor of the Campo de Gibraltar, 14 August 180o, AHN, Estado, leg. 5802.

84 Adrián Jacome to Mariano Luis de Urquijo, Campo de Gibraltar, 25 August 180o. AHN, Estado, leg. 5802.

85 Petitions dated in San Ildefonso, 15 August 180o, and San Lorenzo de El Escorial, 13 October 1800, AHN, Estado, leg. 5802 .

File on A. Buasa, AHN, Estado, leg. 5802 . 
be named without disgust." He repeated his demand for the return of his ship, cargo, and money. He claimed that the king of Spain had accepted his appeal, though the royal command had not yet reached the tribunal at San Roque. And finally he lamented the nine months he had spent in detention. ${ }^{87}$

In a new petition in May 1801 the Moroccan related that he was living in the Posada de San Antonio, number 18. He had obtained "the health certificate from the consul in Almería," and the corsairs had captured him within sight of San Roque, robbing him of everything. Like many captains and merchants in similar circumstances he had decided to approach the court in Madrid for a solution to his problem, though he had been obliged to "sell his clothes in Málaga to be able to go to the royal court to explain to His Majesty his deplorable situation. In fact he sought the king many times in Madrid, in La Granja, and in El Escorial begging for consideration of his request, without failing to visit the Secretariat of State every day to learn of any favorable response to his queries." He insisted that according to an official at the Secretariat of State, the monarch "had granted what he wished, a piece of news that filled the petitioner with joy." He had therefore given "a power of attorney to a confidant of his in San Roque, who would go in his name to the military governor of that port and claim his confiscated goods, by virtue of the favor [the king] had granted." Contrary to his expectations, however, the official claimed to have received no such order. Buasa renewed his "humble requests" in hopes that the monarch "might deign to gaze on him with compassion, for God alone knows of his miserable state; he is so afflicted here that every day seems like a year." In the meantime he had contracted debts that made it impossible for him to travel to the summer palace at Aranjuez, and "as a foreigner he finds no one to aid him in his extreme poverty." Significantly, he now limited his appeal to "whatever alms you may wish to give him," which he hoped to receive "as a son of Adam." He closed by recalling that he had spent "eleven full months" in his suit, for his ship had been seized "before the feast of Saint John [24 June]" of 1800.88

\subsubsection{Hach Hamet Absalem (180o-1801)}

Hach Hamet Absalem, ${ }^{89}$ captain of the fishing boat Misiana and "a subject of His Moroccan Majesty," was captured off Estepona after leaving Málaga. He was accused of being bound for Gibraltar, which was blockaded at the time.

87 Petition by Captain Abdesalam Buasa, Moroccan felucca Masud, Madrid, 22 March 1801. Signed in Arabic, AHN, Estado, leg. 5818.

88 Petition by Abdasalem Buasa, Madrid, 17 May 1801, A HN, Estado, leg. 5818.

89 He also appears as Jach Absalem, Jach R Het Absalem, Jet Absalem, and Jach Jet Salem. 
The judge advocate of the Campo de Gibraltar's military tribunal reported in February 1800 that the captain carried no papers to confirm the purchase of the boat; he had only certificates from the consuls of Spain, Portugal, and France dated in 1797, but he claimed that the boat had been bought in 1799 . There was no proper accounting of the cargo, no required waybill, and no other document except for a certificate from the port of Tavira that did not accord with statements by the captured men. After hearing from the captain and his purser (whom he mistrusted), the judge concluded that "under cover of the Moorish flag even Spaniards trade with the enemy port." The boat and its cargo were therefore confiscated. ${ }^{90}$ José Coronel, who commanded the corsair vessel that had detained it, believed its owners to be Spaniards who were using the Moroccan flag to smuggle food into Gibraltar. The number of Moroccan crewmen did not correspond to the list in the captain's papers:

The detained vessel ought to be a legitimate prize because its captain did not present a deed of sale or genuine document to prove it belongs to the governor of Tangier, as the captain himself admits in his statement. The certificates from the three consuls of Spain, Portugal, and France are of no value for this purpose, because the number of Moors they mention has not been found on board. Nor are they sufficient in themselves to prove the ownership of a vessel whose type of construction, the timber of which it is built, and the marks on its hull from repairs and beaching clearly show it to be Spanish, of those built on the shores of Valencia. If it does belong to subjects of His Moroccan Majesty, why does he not show the bill of sale? No such document exists, and for this reason alone it should be a legitimate prize according to Article 31 of the rules of corsair warfare.

The mere fact that the number of Moroccans aboard did not match the muster roll of crewmen was enough to declare it a prize:

It should also be so by the royal decree of 24 April 1797, through which His Majesty authorizes armers of corsairs to detain every suspicious vessel: if the crew does not correspond to what it should be, native to the country where it is registered, it is declared a prize in their favor. A single Moor is not the crew native to the country as expressed in this royal decree;

90 Report by Manuel Serrano y Cuevas to José Coronel, Algeciras, 16 February 180o, AHN, Estado, leg. 5803 . 
rather, to judge by most of the men found on board, the class and construction of the vessel, its cargo, and so on (as set forth in the report of the chief accountant for the Royal Marine Customs House of the City of Málaga), it is easy to see that it is a Spanish boat that is abusing the Moroccan flag to bring products of our kingdoms into the port of Gibraltar in a trade that is as illegal as it is forbidden.

Besides, even if it did have Moroccan owners ("which cannot be shown with genuine documents"), that would not explain the presence of weapons on board:

To what end would it carry on board the sabres, bayonets, cannon, blunderbusses, firebombs, and other arms and gunpowder that were hidden, enough weapons for every member of the crew? If the captain bought them to arm his ship, where is the patent from his prince that allows it? And if they are a shipment or transport they are smuggled goods, and in either case His Majesty declares it a legitimate prize according to Articles 28 and 33 of the corsair regulations.

Other clues also pointed to smuggling into Gibraltar, including a document "in the pocket of a jacket that was found aboard with a pair of pantaloons and a pair of boots that had no owner, as well as kerchiefs and other bundles of smuggled cloth, which were deposited in the administration of San Roque." He recalled another recent case in which the same arguments had been used: "We have just confiscated and distributed a mistico flying the Moroccan flag, seized by Don Juan Barhen's corsairs, for the well-founded reasons expressed in the report; and without doubt they are less compelling than in the case of the fishing boat at issue here."91

91 "El Casco de la referida embarcación detenida deve ser de buena presa, por no haver presentado su Arraez, escritura o documento legitimo que acredite ser propio del Governador de Tanger; como dice el mismo Arraez en su declaracion, no siendo de ninguna fuerza para esta justificación, las certificaciones de los tres Consules de España, Portugal y Francia, quando no se ha encontrado á bordo el numero de Moros que ellas expresan, y quando ellas solas no son suficientes para acreditar la propiedad natural de un Buque cuya clase de construcción, maderas de que se compone, las señales que conserva en sus fondos de haber tenido carenotes, y los dados para barar, clara y evidentemente manifiestan ser un Buque Español de los construidos en las Playas de Valencia; y por lo tanto si pertenece á Subditos de S. M. Marroqui; por que no presenta ó en donde para la escritura de compra. No existe semejante documento, y por sola esta falta deve ser de Buena presa con arreglo al articulo $3^{1}$ de las ordenanzas de corso. ... Debe igualmente serlo por la Real orden de 24 de abril de 1797 por la que encarga S. M. a los armadores de corsarios detengan a todo 
The military governor of the Campo de Gibraltar agreed with the reports by Manuel Serrano and José Coronel, as he informed the Secretary of State: it was a case of smuggling into Gibraltar and the supposed final destination was "a dodge for taking the other goods 'for Tavira' to cover for the trade conducted under this flag by Spaniards themselves and Englishmen, so as to provide that port continuously with food and all kinds of refreshments." He too thought the boat had been seized lawfully, "as has just happened with another ship taken by two Spanish corsairs as it left Gibraltar." He hoped that the monarch could judge the legality of the prize, as encouragement to Spanish corsairs and warships that were pursuing that traffic:

Thus we would stimulate the capturers to increase their zeal, to avoid the constant introduction of foodstuffs into Gibraltar, with illegal goods exported in return, that so harms the Royal Treasury. They use their own subjects for this criminal commerce and put two or three rented Moors on board, buying the passports of others involved in the expanding commerce that takes place in Gibraltar, and they sell out the Moors and the English. ${ }^{92}$

buque sospechoso, pues si la tripulación no correspondiese a la que debe llevar natural del Pais a que pertenesca su propiedad se declarará la presa á su favor. Un solo Moro no es la tripulación natural del Pais que expresa esta Real orden, antes bien si se juzga por el mayor numero de gente encontrada a bordo, por la clase y construcción de la embarcación, y por el Cargamento y demas que consta en el informe del contador principal de Rentas Generales de la Real Aduana de Mar de la Ciudad de Malaga fácilmente se inferirá que es una embarcación Española que abusando del Pabellon Marroqui se empleaba en conducir á la Plaza de Gibraltar las producciones de nuestros Reynos con un comercio tan ilícito como prohivido. ... [P] ara que fin llevaba a bordo, los sables, bayonetas, pedrero, trabuco, frascos de fuego y demas municiones y polvora que se encontraron escondidos; armas suficientes para todos los individuos de su tripulación: Si el Arraez las compró para armar su Buque en donde esta la patente de su Principe que lo permita; y si de carga ó tansporte son efectos de contrabando, y en uno y otro caso la declara S. M. por de buena presa según los artículos 28 y 33 de la ordenanza de Corso." Coronel affirmed having made the same arguments in a report dated the previous 27 January: José Coronel to Count de la Haye-St. Hilaire, Algeciras, 20 February 1800, AHN, Estado, leg. 5803.

“...de cuyo modo se dá mucho estimulo a los Apresadores para que aumenten su vibo celo, en evitar la continua introducción de viberes que se haze en Gibraltar, exportando fraudes en retorno, que tanto perjudica al Real Erario, valiéndose sus propios vasallos para cometer tan criminal comercio, de poner alquilados a bordo dos, o tres moros, y comprar a otros algunos de los Pasaportes que traen, del crecido comercio que circula en Gibraltar, y venden los Moros e Yngleses": Count de la Haye-St. Hilaire to Mariano Luis de Urquijo, Campo de Gibraltar, 24 February 1800, AHN, Estado, leg. $5^{803 .}$ 
The Secretary of State agreed with the military governor that the boat was a legitimate prize, and urged him to publish the decision if he thought fit. ${ }^{93}$

In April of that year Hach Absalem appealed to the military governor of the Campo de Gibraltar. He complained that after he sailed from Málaga for the Portuguese city of Tavira his boat had been seized in Estepona, and he wished the matter to be officially recorded: "Having left Málaga loaded with bread, flour, wine, and vinegar, bound for Tavira in the king[dom] of Portugal, the boat was intercepted in Estepona and its cargo decommissioned. To this end he requests Your Excellency to provide the proper witness statement, for that is only just." ${ }^{\prime 94}$ The military governor ordered the scribe of the military tribunal to issue the appropriate document. ${ }^{95}$ It stated that Captain José Coronel, commander of the felucca fleet of Estepona, had seized the "Moroccan boat" for "having aboard a load of skins of red wine, sacks of flour, and other items without the necessary waybills." The hearings began on 23 January 1800 and concluded with a sentence handed down in San Roque on 12 February, which confirmed that part of what had been loaded in Málaga (bricks and turkeys) had been taken to Gibraltar, while other products did not have the required permits and had not paid duties:

Because Captain Hach Jet Salem gives no justification nor satisfaction about the purpose and destination of the seven thousand bricks and twenty turkeys that, according to the certificate from the chief accountant of the tax office in Málaga, he loaded onto the boat under his command on 2 and 18 January last; it being assumed that he would have transported those goods to the port of Gibraltar, and did so without the corresponding waybills and payments of duties on the flour, chickens, biscuit, and lemons that make up his cargo: as Your Excellency has stated, according to the royal regulations [the cargo] should be declared confiscated in toto. The boat is set at liberty and the captain is warned to abstain from similar actions in the future, otherwise he will be dealt with severely.

To avoid spoilage of the seized items they were to be sold at public auction, with the profits set aside pending the king's decision. It was published on 13 March and communicated two days later to the capturer, José Coronel,

93 Mariano Luis de Urquijo to military governor of the Campo de Gibraltar, Aranjuez, 4 March 1800, AHN, Estado, leg. 5803 .

94 File "Barca Bou, Misiana, recurso de su arráez marroquí Jach Absalen y del apoderado de este Santiago Escalar y Calzada, San Roque, 4-4-180о," AHN, Estado, leg. 5803 . San Roque, 3 April 180o, Count de la Haye-St. Hilaire, AHN, Estado, leg. 5803. 
and after another week to Captain Absalem. In the presence of three witnesses Absalem was told that he could appeal the sentence within a certain time if he found it unjust; it would be considered final if not appealed by 1 April. At that point the value of the auctioned cargo was distributed and the boat, with its papers, weapons, and other effects, was returned to the captain. Antonio González Salmón, the new consul, informed the sultan of the events and the arrangements to have the captain sail the boat back to his country. ${ }^{96}$

Not satisfied with this finding, Captain Absalem sent a new petition - after the stipulated period had closed - that repeated all his earlier arguments and pleaded his condition as an outsider: "Because the petitioner is a foreigner he could not understand the reasons for his detention. And although he took many steps and made his requests to be freed of such obstruction he obtained nothing, because he did not know how to prepare his defense before the court, confident that the judge would allow him to pursue his voyage." "Stripped of his goods and ruined," he had tried to understand the events: "He asked for the testimony of that proceeding, the same one that humbly accompanies this statement and forms its basis. He declares that it was only through a defect in the waybills that he was decommissioned and lost his entire cargo." Once the sentence was published, "though he was allowed to appeal to the Council," he was

incapable of seeking that remedy because he lacked all help and even what was needed for his sustenance and that of his crew. Afflicted with the misfortune of this circumstance he was forced to return to Málaga with his boat, to petition Your Excellency and explain to his wise counsel that in this case he has been accused of a crime that he did not commit.

96 “[Q]ue respecto á que el Arraez Hach Jet Salem, no dá razón, ni satisface al cargo que le resulta sobre el destino, y paradero de los siete millares de Ladrillos, y veinte Pabos, que según aparece de la certificación del Contador principal de Rentas Generales de Malaga embarcó en el Buque á su mando en dos y diez y ocho de Enero ultimo, siendo presumible, hubiese transboradado estos efectos para su Conduccion á la Plaza de Gibraltar, y que asimismo lo hizo sin las Correspondientes Guias, y pagos de derechos de la Harina, Gallinas Galletas, y Limones de que se compone su cargamento, devia declarar como declaraba S. E. por caydo en comiso este en todas sus partes, con aplicación según Reales Ynstrucciones, quedando en libertad el Buque, prevenido dicho Arraez que en lo Sucesibo se abstenga de dar lugar a iguales procedimientos, pues de lo contrario se le tratará con mayor demostración": "Certificación de Juan de Mena escribano del rey y numerario de la ciudad de Gibraltar y del Tribunal de Guerra de la Comandancia General y Ejercito del Campo de San Roque," 4 April 180o, AHN, Estado, leg. 5803. 
And even if it were true he did not deserve the decommissioning and loss of his cargo, and that has been done in a manner that goes directly against the royal decrees. ${ }^{97}$

He argued that the missing waybills for the "small amounts" of flour, wine, and lemons were not the result of ill intent but of his ignorance of the "norms of this country": "On purchasing those items he had dealt with the sellers in charge of loading them for the agreed price, and they were responsible for obtaining the licenses, something a Moor cannot understand as one alien to every practice in this country. Therefore he received those items in good faith, believing them licit in every way."

Even if the petitioner should have obtained the necessary waybills, however, he recalled that in similar cases the problem had been solved by imposing double the usual customs duties, since there had been no "fraud involving items forbidden to be traded." Therefore he denounced "the unprecedent strictness used by the official from San Roque, without considering the circumstances and without due respect for the king's generous indulgence toward Moroccans in Spain." The sentence had ignored the good relations between Spain and Morocco and the terms of the Peace Treaty of 1799:

That official ignored the provision of the treaty of peace between the two sovereigns of 1 March of last year. Article Six states that that even if the petitioner had committed a serious offense he could not be brought to court nor deprived of his goods. More specifically, Article 34 that deals with cases of fraud forbids the decommissioning and loss of captured goods, even if they are illicit. None of this has been observed in the present case, causing ruin and harm to the petitioner against the sovereign's desire and solemn agreement; and this in spite of the enlightened and admirable instruction given to that judge regarding the royal decree related to that witness statement, i.e., that the sentence should be made public if it conformed to the law.

97 “...incapaz de emprender este remedio, careciendo de todo auxilio, y aun de lo necesario á su sustento, y el de su Tripulacion: Aflijido con la desgracia de este accidente se vió obligado a regresar a Malaga, con su Barca para ocurrir a V. E. y representar á su sabia justificacion que en la referida causa se le ha figurado un Crimen, que no ha cometido; que aunque fuese cierto, no exigía el comiso, y perdida de su cargamento y que el haberlo practicado asi ha sido quebrantando directamente las Reales ordenes": Petition by Hach Absalem, Málaga, 10 June 1800, AHN, Estado, leg. 5803. 
His lack of the proper waybills should not have made him lose his cargo, nor was there a basis for confiscating it and taking him to court. He decried the "irregularity" of the proceedings in San Roque and demanded "a swift remedy for the ills and harms caused him ... stripped of his goods and treated with indifference in a foreign land." He wanted the sentence reversed and his cargo, or its value, returned "with restitution for the damages and injuries he has suffered; being prepared to satisfy the duties resulting from defects in his waybills, though without acknowledging ill intent in loading [the goods], as he has explained."98

The military governor of El Campo de Gibraltar was forced to tell the Secretariat of State again that he defended José Coronel's capture of the boat and that the sentence had been fair - and had not been "appealed by the capturers nor by the Moor, even though [that right] had been explained to him in the clearest of terms." The captain's petition was therefore unfounded, although contrary to royal decrees ("which make no exceptions for Moroccans") his boat, considered a legitimate prize, had been returned and the crew maintained at the capturers' expense. The captain's accusations against the justice imparted in the local court were "as improper as they are false," so the Commandant hoped that his superior would "investigate and reprimand severely the person who has influenced [the captain], doubtless through some Spaniard who owns the boat and cargo and under the shelter of the Moroccan flag is supplying Gibraltar, committing serious frauds and other excesses that are very harmful to the service of the king and his royal income. ${ }^{99}$

In August 1801 Santiago Escalar y Calzada, representing Hach Hamet Absalem and in his name, after the king had refused to review the affair requested the relevant court documents and reports "to exercise his right to use them as he wishes." This petition was granted.100

98 “[D]esatendió dicho Subdelegado, á lo prevenido en el tratado de paz entre ambos soberanos, de primero de Marzo del año próximo pasado,pues según el Articulo sexto aun quando el exponente hubiera cometido un grave delito, no se podía practicar diligencia alguna judicial contra el, ni privarle de sus bienes; y con mas especificación se dispone con el Articulo 34 tratando de aprencion de fraudes, pues se prohíbe el Comiso, y perdida de los generos aprendidos, aun en el extremo de ser ilicitos. Nada de esto se ha observado en aquel procedimiento, Causando la ruina y agravio del exponente, contra la voluntad y solemne convenio del Soberano, a pesar de la luz y admirable advertencia que se hizo a aquel Juez por la condicion contenida en Real Orden de relaciona dicho testimonio, en los términos de que publicase su sentencia si la creyese arreglada a derecho": Petition by Hach Absalem, Málaga, 10 June 1800, AHN, Estado, leg. 5803.

99 Count de la Haye-St. Hilaire to Mariano Luis de Urquijo, Campo de Gibraltar, 3 July 18oo, AHN, Estado, leg. 5803 .

100 Santiago de Escalar's petition is dated in Madrid, 28 August 1801. On the surrender of the documents: "I received from Don Eusebio Bardaxi, official of the First Secretariat of State 
The last document we have related to Hach Hamet Absalem also comes from Santiago Escalar: a petition he presented in October 1801 in defense of his client. It acknowledged that the boat had left Málaga with a shipment for Tavira that had the proper documentation. It was seized in Estepona, where "a lawsuit was brought by the associate justice of El Campo de San Roque." The captain, accused of carrying part of his cargo without waybills, had his goods confiscated and sold, while the boat was returned to him. As a foreigner he did not understand the reason for his detention and could not mount an adequate defense:

Not having understood, as a foreigner, the reasons for his detention, though he took many steps and voiced his requests that he be freed from this impediment, he achieved nothing, since he did not know how to prepare his defense in court, being sure that the judge would allow him to continue his journey. But after the captain was stripped of his property and ruined, he sought to learn the cause and circumstances of this event, for which he asked for a statement of the proceeding. It is the one that humbly accompanies and forms the basis for this appeal.

The captain continued to claim that royal decrees on the matter had been contravened, though without any detailed argument; he recalled that his sentence was made public "but could be appealed to the Council." If the king's decision to publicize the sentence had a basis in law, there was only one conclusion to be drawn: "Let him notice and reflect that the sentence does not fulfill these conditions in either substance or manner; for if the lack of waybills allowed the cargo to be seized, the decommissioning and the development of the suit had nothing to do with a fraud by the Moor." The Moroccan was in no position to understand the situation, and was " incapable of remedying it, since he lacks any help and even basic sustenance for himself and his crew, and is afflicted with this unfortunate circumstance." He could only return to Málaga and from there appeal the sentence "that has imagined him author of a crime he did not commit; and even if it were true it did not require the decommissioning and loss of his cargo." It was too great a punishment "for the mere lack of waybills for part of the cargo,"

in charge of Moroccan affairs, the documents presented by Don Santiago de Escalar on a petition by Jach Abselem captain of the fishing boat, as the representative of that Moor. San Lorenzo, 7 November 1801". Signed by Santiago de Escalar and his brother José Luis de Escalar, AHN, Estado, leg. 1801. 
that small amount of flour, some wine, and lemons; this was not the captain's fault, nor did he wish to deprive the king of duties on his shipment. Such small amounts should not be subject to detention and damages; he claims that when he bought those items he dealt with sellers who were to bring them aboard for contracted prices and manage the tasks of loading and obtaining licenses, something that a Moor alien to the practices of this country was ignorant of. Therefore he received that merchandise in good faith, believing it legal in every way.

He argued that in similar cases, if it was a first offense, it could be settled by paying double the normal duties, and that should have been done for him. The judge in San Roque, with his "extraordinary severity," had ignored

how the king's generosity wishes that Moroccans be treated in Spain. And besides, the judge contravened and ignored stipulations of the Peace Treaty between the two sovereigns of 1 March last year: by Article 6, even if the Moor had committed a serious breach he could not be sued or deprived of his property. And more specifically Article 34, which deals with the detection of fraud, forbids the decommissioning and loss of seized goods, even if they are illegal.

None of that had been observed, "causing ruin and harm to the captain," and the court proceeding in San Roque had been irregular. "With reason the Moor begs for speedy relief from the assaults and evils caused to him: [he is] stripped of his goods and reduced to the greatest poverty." The captain's case should be heard again even if it was already considered closed, in view of

his ignorance of the laws and regulations of these kingdoms. The result will show his ignorance and perhaps the collusion that occurred in loading this boat by a vassal of Your Majesty who should have proceeded with more good faith and understanding of the common and general rule that governs such dealings and shipments. ${ }^{101}$

101 “...sin haver comprendido como estrangero los motivos de su detención, aun que dio muchos pasos é interpuso sus ruegos, a fin de que se le librase de tal molestia, nada consiguió, por que no supo entablar su Defensa en Justicia, confiado en que aquel Juez le permitiría seguir su viaje; pero luego que se vio despojado de sus bienes, y perdido dicho Arraez, procuró saber la causa y circunstancias de tal suceso, y para ello pidió testimonio del referido procedimiento que es el mismo que humildemente acompaña, y sirve de fundamento a este recurso. ... la corta porción de arina, algun bino y limón de su carga no fue por culpa del Arraez, ni por que con dolo quisiera pribar al Rey de los derechos. de su 


\subsubsection{Hach Mekki (1800-1801)}

In June 180 o corsairs from the Algeciras supply squadron seized two ships that had emerged from the blockaded port of Gibraltar; both were declared legitimate prizes. Chartered by the Bey of Mascara with the help of a Tunisian and two Moroccans, they had undoubtedly brought in wheat and barley. A search of one of them, La Dama Veneta under the imperial flag of Morocco, turned up ten thousand pesos fuertes. ${ }^{102}$

Amid a burgeoning correspondence among the interested parties a Moroccan merchant from Salé, Hach Mekki, arrived in San Roque in the Campo de Gibraltar. ${ }^{103}$ In a petition dated 14 August he identified himself as the owner of the confiscated ten thousand pesos. He claimed authorization to trade under a neutral flag, though he mentioned in passing that he had not realized Gibraltar was blockaded. The ship's captain might have committed a crime, but that had nothing to do with him. ${ }^{104}$ In a second petition, from San Ildefonso, he stressed that as a foreigner he sought the protection of the Secretary of State about a decision by the Prize Board of Algeciras, which affected " the sum of two hundred thousand reales de vellón that he claimed, which had been combined with

embarque, pues siendo de corta entidad por ello no se havia de exponer a detenciones y perjuicios; únicamente fue dimanado de que al comprar dichos efectos, trató con los vendedores que se los havian de poner a bordo por el precio ajustado, quedando al cargo de aquellos las faenas de conducción y facilitación de licencias, como cosa qe no entendia un Moro ageno de toda noticia en la practica de este Pays: Asi recivió de buena fee dhos efectos creyéndolos habilitados en toda forma; . ... a la indulgencia con que la piedad del Rey, quiere sean tratados los Marroquies en España: Pero además contravino, y desatendio dicho Subdelegado a lo prevenido en el tratado de Paz entre ambos soberanos de $1^{\circ}$ de Marzo del año próximo pasado, ps. según el art $^{\circ} 6^{\circ}$ aun quando el Moro hubiera cometido un grave delito, no se podía practicar diligencia alguna judicial contra el, ni privarle de sus bienes: $\mathrm{Y}$ con mas especificación se dispone en el $\mathrm{art}^{\mathrm{o}} 34$ tratando de apreension de fraudes, pues se prohive el comiso y perdida de los generos apreendidos, aun en el extremo de ser ilícitos. ... la ignorancia que en este concurre de las Leyes y disposiciones de estos Reynos, y a que por el resultado aparecerá su ignorancia y tal vez la colusión, que intervino en el cargo de esta embarcación, cometido al vasallo de V.M. que devio proceder con mas buena fee e inteligcia de la común y gral regla qe deve regir para semejantes negociaciones y trasportes": Madrid, 28 October 1800.

102 Duke of Frías to Mariano Luis de Urquijo, 7 and 16 October 180o. Italian translation of a letter from the Bey of Mascara to Mariano Luis de Urquijo, 22 October 180o, AHN, Estado, leg. 5806 .

103 He also appears as Jach Mechi, Jach Mekki Haffe, Jach Michy Jafi, Miki el-Jafy, and Jach Mili El-Jafi.

104 A marginal note on the document reads: "Let him exercise his right according to the law" and "It has been told to him verbally." Petition by Jach Mechi, San Roque, 14 August 18oo, AHN, Estado, leg. 5806. 
those involving the captain and the ship by the mere fact of having been on board, without considering arguments in favor of the petitioner's innocence."

Aside from the pesos fuertes at issue, Hach Mekki sought compensation for the damages he had suffered unjustly, so that he could continue to trade. ${ }^{105}$ The Court asked for more information and the military governor of the Campo de Gibraltar reported to the Secretary of State that the two imperial ships $L a$ Dama Veneta and El África had been captured after a fight at sea. As for the Moroccan who claimed ownership of the ten thousand pesos fuertes,

the Moorish merchant from Morocco in charge of the money and other items that the Bey claims came to see me asking them to be returned because they are at peace with Spain. And he did not and could not cause the captains of the frigate to enter into combat. And he, like all Moors, normally traveled carrying their money without any documentation, while seeking to protect it carefully to avoid its being taken. ${ }^{106}$

Almost a year later Mekki wrote again, claiming that he had chartered the frigate in question in Livorno with José Ballarino as its captain, intending to sail to a Moroccan port so long as there was no pestilence there; they had entered Gibraltar seeking information on that point and had been told that plague was still present. He had sold his cargo, which was wholly his own property, in that port and obtained ten thousand pesos fuertes. Since Morocco was closed to them he sought another destination and decided on Oran, having learned that the Bey of Mascara was chartering ships to load wheat there. Just out of Gibraltar they had been intercepted and fired on by an unflagged felucca that called for their surrender; they attempted a defense, but were within range of cannons from Algeciras. Mekki asked for the return of the full sum, because he had been a mere passenger under the captain and was a vassal of a nation friendly to Spain. Again he claimed ignorance of the Gibraltar blockade, since it had been proclaimed on 12 March, the day they had sailed from Livorno, and they had no way of knowing about it. He then insisted, however, that

105 On the margin is written: "He is denied, and rightly." Petition written in Arabic and dated in San Ildefonso, 12 September 180o, AHN, Estado, leg. 5806.

106 "[E]l Moro comerciante de Marruecos encargado del dinero y demás efectos que reclama el Bey, vino a berme solicitando su entrega fundando en que estando en Paz con España, que de ningún modo tubo parte, ni pudo tener en que los Capitanes de la Fragata sostubiesen el combate, y que el como todos los demás moros acostumbraban en su continuo giro a llebar el dinero sin documento alguno, procurando resguardarlo con el mayor cuidado, para evitar toda extracción": Count de la Haye-St. Hilaire to M.L. de Urquijo, Campo de Gibraltar, 24 November 1800, AHN, Estado, leg. 5806. 
neutral-flagged ships could enter that port to buy and sell freely. After the ships had been judged as prizes he had returned to Morocco, where a minister had written to the Secretary of State demanding justice. ${ }^{107}$

A few weeks later Hach Mekki appeared at the royal summer residence of San Ildefonso and presented another petition: he was charged by Osman, Bey of Mascara and Oran, with putting into the king's hands a letter in Arabic, which he had brought together with its Italian translation. ${ }^{108}$ The letter was signed by the Moroccan minister Sid Mohamet El-Salahui and addressed to Vice Consul Antonio González Salmón; it asked for justice in the case and stated that the emperor had written to the vice consul's brother, J.M. González Salmón, about the affair. He therefore hoped that "you will not allow [Mekki] to return to the noble presence of our master (exalted by God) without a satisfactory conclusion to the business that has taken him to your country."109

We see how the Moroccans combined claims of ignorance about the Gibraltar blockade - which could have been genuine - with their right to sail under a neutral flag, which in fact did not apply to a blockaded port. The letters from Bey Osman of Mascara and the Moroccan sultan's minister made the same point. But Mekki could not present any proof that the money was actually his. Both he and the frigate's captain appeared in person before the Supreme Council of War before it made its decision. ${ }^{110}$

Mekki drew on all the influence he had in Morocco. The vice consul in Tangier, Antonio González Salmón, conveyed his demand for the return of the money and other items to the Secretary of State in September 1801: "I have just received a recommendation in the Moor's favor from Prince Muley Abselem, who takes an interest in the swift return of the property of a subject of the king his brother." It happened that Mekki's brother was the governor of Salé and an influential figure at Muley Sliman's court, and "if we do not attend to him we will incline that magnate against us, even if we argue that it is our right while we have Gibraltar under blockade." In the vice consul's opinion the Moroccan captain was at least partially correct, and it was best to place the nation's general interest above that of private armers of corsairs, and to be flexible in the present case, otherwise

107 Petition of 20 August 1801, signed in Arabic, AHN, Estado, leg. 5806.

108 Petition of mid-September 1801, AHN, Estado, leg. 5806.

109 Cádiz, 10 August 1801, AHN, Estado, leg. 5806.

110 The Council declared both Captain Ballarino's frigate and the money it carried a legitimate prize. It assumed that the Moroccan's account was false and that he was concealing the true ownership of the pesos fuertes: Manuel Serrano y Cuevas to Count de la Haye-St. Hilaire, 25 November 180o, AHN, Estado, leg. 5806. 
the government of Morocco will never be satisfied; it is very true that the Moor, when he entered Gibraltar coming from Italy, did not know that we had that enemy port under blockade. Finally, excellent Sir, your keen political sense will realize that there are times when it is best to place the good of the State and the general interest of the Nation above the private interest of some armers of ships, or of the capturers of neutral vessels. ${ }^{111}$

In a later communication the vice consul requested documentation that the pesos fuertes did not belong to Hach Mekki; that would reassure Muley Sliman and also "quiet the demands of Jafi, who continues his appeal with the greatest vigor at the court of Muley Soliman." 12

\subsubsection{Achijamet and Jamet (180o-1801)}

These two Moroccans ${ }^{113}$ were robbed in Cartagena on 7 November 1801: "eleven thousand reales de vellón and all their clothing, valued at 250 pesos," were taken from their room. As a result, they claimed to be "in utmost penury" and suffering "great hunger, so much so that they have been helped by persons moved by charity who have offered them partial relief"; they hoped the monarch would assist them. A search for the stolen funds had located "three men held in the royal prisons who were found that night in possession of 231 duros (now held in deposit) in equal shares. As reported in court papers, they confessed that they committed the robbery with another two men who have not appeared, but they do not want to confess where they hid the clothing and the rest of the money."

The Moroccans asked that the men feel the full force of the law, be made to declare where they were keeping the money and clothes, and receive the appropriate punishment. They pleaded their foreign status as "these unhappy men who are in a foreign kingdom without any consul or ambassador to ensure justice, which we hope to receive from His Majesty's generous charity."114

111 “[J]amás se dará por satisfecho el Gobierno Marroquí por quanto es muy cierto que el Moro, á su entrada en Gibraltar procedente de Ytália, ignoraba estubiese bloqueada por Nosotros aquella Plaza Enemiga, y por ultimo, Señor Excmo. la acendrada política de V. E. reconocerá que hay lanzes en que conviene anteponer el bien del Estado é interés general de la Nacion, al interés particular de algunos Armadores, ó Captores en la interceptación de los Neutrales": Antonio González Salmón to Pedro Ceballos, Cádiz, 11 September 1801, AHN, Estado, leg. 5806 .

112 A. González Salmón to Pedro Ceballos, Tangier, 2 April 1802, A HN, Estado, leg. 5806.

113 Who also appear as Gatleche Majamet and Majamet, respectively.

114 Petition by Achijamet and Jamet, who sign in Spanish: Cartagena, 2o December 1800. A marginal note reads: "Attended to on 4 January 1801," A HN, Estado, leg. 5803. 
An unsigned note from Madrid dated 4 January 1801 informed the governor of Cartagena that the king felt pity for the Moroccans who had been "robbed in their house and have lost their money and their clothes." He was urged to be diligent "in discovering the location of their goods and concluding the current case" so that "these Moroccans may recover their lost possessions."115

The governor returned a report on the events. After an investigation the full sum of money had been recovered, but not all the clothing: "all they had been robbed of was found, except for a few articles that may be of little value; still, I will employ every possible means to recover them and conclude the case quickly." The public scribe of the tribunal and town hall wrote a full report of what had happened: "Some Moors and a Hebrew" (i.e., the two Moroccans and a Jew named León Serfaty) "live in a downstairs room in one of the houses attached to the city wall." The first two had been absent and the third upstairs with their neighbors, and on their return they found five hundred silver duros and fourteen gold duros missing: "The said Moors had [them] in a bag of bladder skin tied with a leather cord and placed in a chest, and the Hebrew's clothing was in another chest. They found the entry door to the room open." The scribe began an investigation with the help of local sheriffs and a contingent of the provincial militia; they were accompanied by one of the Moors and the Jew, "who speak and understand our language." They found the chest that had contained the coins with its lock broken and nothing but a pair of slippers inside; the other, where the Jew had stored his clothes, also had a broken lock and was empty but for "a few red pipe stems and other small items which, being irrelevant to the case, were not listed." Some neighbor women, on being asked "if that evening or earlier they had seen any suspicious persons," recalled that three or four days before three men "who looked like sweepers from the Royal Naval Hospital" had gone by, one of them carrying a staff, and had aroused their suspicions by gazing at the Moors' house. They also remembered

a very small man with a round pockmarked face and long sideburns, wearing a blackish cape with green linings and a montera hat. They had seen him speaking sometimes with the Moor who is present. And he [the Moor] replied that it was true: a man like the one the women described had approached him several times for conversation, but he had told him they had nothing to talk about. ${ }^{116}$

115 Unsigned draft note "To the governor of Cartagena," Madrid, 4 January 1801.

116 "[U]n hombre pequeñito, redondo de cara, picado de viruelas, patilla larga, que lleva un capote que tira a negro, con vueltas verdes y montera, lo han visto hablar algunas veces con el Moro que se halla presente, quien contexto ser verdad, que uno de las señas que 
The searchers then moved to the naval hospital, where in the sweepers' bedroom they found a staff belonging to the overseer Francisco Reyes, whom the women recognized. Under interrogation he admitted that he had walked by the city wall with Juan Lillo and Ramón García, a former prisoner. In Lillo's house, under his bed, the authorities found a chest with a bag inside that contained part of the stolen money: two packets that each contained fifty pesos fuertes or duros, and two kerchiefs in which were tied forty-one and four duros, respectively. Those 145 duros equalled 3,620 reales, which were confiscated. Lillo protested that the chest was not his and he did not know where it came from, though he eventually confessed that it belonged to Ginés Fernández, an overseer of the prison at the Arsenal. All the men were arrested and kept in separate cells. García, who was not detained until 8 November, ${ }^{117}$ declared that he had been walking by the city wall one afternoon with Lillo and Reyes when "they saw two Moors come out of a house that is opposite the guard corps. They decided to enter, assuming [those men] had money, and found it was so; while Reyes stayed at the street door the witness shoved the inner downstairs door with his back and with a little effort it opened." Once inside they broke the locks on two chests, removing white and colored clothing and a sack of coins. In their haste Lillo dropped two packets of duros, which García picked up. When two women approached, Reyes disappeared and they could not divide up the money then and there, so they left the clothing behind except for two old shirts that García took, with the pesos Lillo had dropped. (The authorities combed the area near the wall where the clothes and pesos had fallen and found nothing.) García buried his pesos duros next to the first mill on the road out of the city through the Madrid gate, and when he led the officers there they found fifty pesos duros and two old shirts. Altogether 4,620 reales were recovered and returned to the Moroccans on 11 November, by order of the admiral of Cartagena and in the presence of León Serfaty. Efforts to find the remaining money and clothing continued, leading to the arrest of one Fernando García for vagrancy: he testified that on the evening of the robbery he had spoken with a certain Roque who had received the stolen clothes and then left the city.118

dicen las indicadas muxeres, se ha acercado a el en varias ocasiones queriendo combersacion, y le contextaba no tenia que hablar con el."

117 At that point he had been free for two months after eight years imprisoned in the Arsenal for having committed a robbery in Lorca. Not finding work in that city he had moved to Cartagena even though former prisoners were not allowed to live there: AHN, Estado, leg. 5803 .

118 Marquis de la Cañada Ibáñez to Pedro Ceballos, 17 January 1801, AHN, Estado, leg. 5803. 


\subsubsection{Ibrahim Lubaris (1801)}

Captain Brahim Lubaris arrived in Barcelona in September 1801 from Salé, in a schooner loaded with hides, wax, and gum. His case, like many others, shows us that captains (arraeces) of the sultan's warships were willing to engage in commerce as well. Lubaris had served the quarantine during a layover in Alicante, but in Barcelona the Board of Health imposed another strict one because he had not unloaded his goods at the earlier port. The board was obeying royal decrees of 28 October and 5 November 1800 and 14 January 1801, and noted the different health standards imposed in the two cities, "realizing the dissonance it must cause the Moroccan captain, since he was given assurances in Alicante; and how important this is at times to North Africans, causing unjustified resentments and easily resulting in claims by them."119

\subsubsection{Mahomed Ben El Fach Ahmed Mogtal El Tarbelsi (1801)}

After the death of Sidi el Hach Mahomed Ben El Fach, a native of Tetouan, his interests were defended by Sidi Ali Ben El Abar Sid el Hach Yeguia el Mesfigui, also from Tetouan and then residing in Cádiz. He appeared with an interpreter, Hamet Almanzor, "who possesses sufficient knowledge of our Castilian tongue," and with an executor, Sidi Mahomed Ben El Abar Sid el Hach Humida el Amuri. El Amuri brought El Tarbelsi's will, "written in Arabic and properly translated into Spanish" by Spain's vice consul in Morocco, Juan de Campuzano; he came to collect sums owed the deceased man by Benito Picardo, a principal importer of Moroccan wheat. The total amount was slightly over 30,031 silver reales, which he received "in cash in silver coin and not in royal bonds." ${ }^{20}$ It is noteworthy that the Moroccans used a notary's services and had close relationships with one of the most important merchants in Cádiz at the time.

\subsubsection{Taibe Menaiza and Meliro Açabel (1801)}

In 1801 five Moroccans appeared before a notary in Cádiz, where they then resided: Taibe Menaiza and Meliro Açabel from Tangier, Jamete Melfa and Jamete Zen Zen from Tetouan, and the interpreter Jamete Almanzor. They declared that they owed 220 pesos fuertes in silver to Benito Picardo. Menaiza was captain and owner of the boat Mesauda of five hundred quintales, "now anchored in this bay."121 It is a second instance of Moroccans using a notary, and we see the names of the interpreter and Picardo once again.

\footnotetext{
119 Report to Miguel de Prats, 29 August 1801, Iм нв, Fs, Serie v, leg. 13, fols. 94-96.

120 Notary José Gómez Torices, 1801. Caja 1891, fols. 479-85, AHPC.

121 Notary José Gómez Torices, 1801. Caja 1891, fol. 231, AHPC.
} 


\subsubsection{Ali Turqui (1801-1803)}

On 29 May 1800 Captain Ali Turqui, ${ }^{122}$ owner of the polacre Bermeja or Merboja of two thousand quintales, signed a charter contract with two merchants from Cádiz, Cristóbal Quintana and Marcos Herreros. He agreed to make a round trip from that port city to Santa Cruz de Tenerife, but he never did so because while the ship was being loaded, a royal decree reached Cádiz ordering Moroccan ships in Spanish ports to return home carrying nothing but ballast; it was a repetition of an earlier decree. Turqui appealed to the consular tribunal in Cádiz demanding payment from Quintana and Herreros of "half the charter fee and the delays, damages, and harm caused him by their non-fulfilment" of the contract; he calculated that if the charterers had finished loading the ship in the time agreed upon, he could have sailed for Tenerife before the royal decree arrived; therefore they bore responsibility for the failed voyage. In August 1801 the consul decided that Ali Turqui should be paid "half the charter fee agreed to in the contract; days of delay, from 16 June 1800 to 12 February 1801 , at three hundred reales de vellón per day in accordance with the agreement; and also 11,907 silver reales and twelve and a half cuartos for the damages the polacre suffered from the delay."123

Quintana appealed to a higher court (Juzgado de Alzadas), which after reviewing the sentence between 7 January and 13 November 1802 reversed it and ruled that Quintana owed only ten days' worth of delays at three hundred reales per day. Quintana and Herreros were also demanding that the captain return the portion of their cargo that was still aboard the polacre. Turqui argued in his petition to the king that the voyage had been canceled through the two merchants' inaction in not having the ship loaded on time; while he was waiting to sail the royal decree had arrived, "ordering the Cádiz authorities to issue no papers to any Moroccan ship except for its return to Morocco." He wanted the decision of the consular court in Cádiz, which had found in his favor, to prevail; that of the Alzadas tribunal had placed him in "an unhappy state." He reminded the king of "the favor that he has been pleased to extend to vassals of His Moroccan Majesty, whom he has seen fit to protect by virtue of the treaties, to the benefit of both nations. He hopes that by trade and commerce each will be useful to the other, legally and in good faith and without both [sets of] subjects having to bring bothersome lawsuits." He requested help in his financial straits, and could not help recalling "in obedience to the truth that during the war with the English, when Spain's fortified ports [in

\footnotetext{
122 In Chapter 7 we met him as a corsair captain.

123 Petition by Ali Turqui dated 25 April 1803, AHN, Estado, leg. 5802.
} 
North Africa] and that of Ceuta were in difficulties through the blockade of Cádiz and interception of trade there, he had devoted zeal and effort to conveying to that port in Africa a variety of goods, facing dangers and and the possibility of losing everything." ${ }^{24}$ Ali presented another petition, reiterating the same terms, on 13 May. ${ }^{125}$

On 6 May 1803 the Secretariat of State asked the consulate in Cádiz to investigate and give its opinion. ${ }^{26}$ One of its employees also reviewed the case, and though he blamed the charterers for not having loaded the polacre on time, he agreed with the sentence of the Juzgado de Alzadas because the royal decree had reached the city while the loading period had not yet expired. ${ }^{127}$ As a result, a royal decree of 11 August 1803 stated that the king, "desirous of offering the Emperor of Morocco fresh proof of his special consideration for his subjects," would name an ad-hoc "Junta of the Ministers of his Council" of the Treasury. It would finally, "with no more hearings or allegations from the two sides, examine the documents that exist, pronounce a fair sentence, and announce it to you."128 That body met and, after reviewing the briefs, decided that the decisions of the Juzgado de Alzadas on 7 January and 13 November 1802 had been "fair and conformed to the Orders of the Consulate of Bilbao

124 The chartering merchants were supposed to pay the captain 50,ooo reales in cash - never in royal bonds - on his return to Cádiz. The cargo was to be approved in the space of fifteen working days, with an allowance of ten additional days charged at 300 reales de vellón per day. There was a surcharge of 4,0oo reales for excess cargo. The captain was to deposit 1,00o pesos fuertes with Antonio Salmón, Spain's consul general in Morocco, in case the polacre should be intercepted at sea and taken to any port other than its destination; and if the captain did not defend properly the charterers' right to the cargo, he would lose those 1,00o pesos to them. Petition by Ali Turqui dated 25 April 1802; copy of his appeal to the Royal Consulate in Cádiz, but dated in Aranjuez, 6 May 1803. Copy of the contract. He insisted on the "solicitude" of the Spanish monarch toward Moroccan subjects: AHN, Estado, leg. 5802 .

125 Petition by Ali Turqui, 13 May 1803, AHN, Estado, leg. 5802.

126 Calixto Sanz, scribe of the Juzgados de Alzadas, reported that when the royal decree had reached Cádiz the polacre was partially loaded: Cádiz, 27 July 1803. Felipe Román claimed that the Alzadas tribunal had studied the case thoroughly, "sparing no effort to determine the truth. And I believe that having heard the litigants irrespective of their nation or religion, subject to the law by which it must judge, it alone must decide and its decision, whether favorable or not, must resolve their differences, for they subjected themselves to its authority": AHN, Estado, leg. 5802.

127 Antonio Ranz Romanillos, jurist and official of the Secretariat of State, to Pedro Ceballos, Madrid, 5 August 1803, A HN, Estado, leg. 5802.

128 Letter from the Governor of the Council of the Treasury, 11 August 1803, AHN, Estado, leg. 5802 . 
and rules of commerce obtaining between civilized nations." Still, it left the final decision in the king's hands. ${ }^{129}$

Ali Turqui petitioned once again with the same arguments on 12 October 1803 , but added that in the earlier version "the attorney who composed it [was] poorly informed by the petitioner because he expresses himself in Spanish with difficulty, knowing almost nothing of that language." He was approaching the king again because "truth and justice do not not lapse with time." He accused Quintana of having bribed witnesses before the Juzgado de Alzadas: "he presented in his support only witnesses whom he had sought out and deliberately bribed; the scribe did not know them, nor does anyone know who they were or from where - a clear proof of the false and untrustworthy nature of everything they swore to in support of Quintana." Besides, Quintana was aware "of the petitioner's lack of resources for continuing the litigation, and inability to find advocates in a foreign country, which would force him to abandon the defense of his rights." We note how the captain placed his faith in Spanish justice: it had been "such an expensive case, which has exhausted all the petitioner's funds and reduced him to the greatest poverty, in a foreign land and far from his unprotected family; but on which the petitioner embarked filled with [the idea of] justice after having taken every friendly and extrajudicial step."

A marginal note on the petition reads: "This petition arrived after the Junta of Ministers appointed to investigate the case had already conveyed its decision to the king." We can assume that the captain was unsuccessful in having that finding reversed in his favor. ${ }^{130}$

\subsubsection{Sidi Abdala Carcet (1801-1807)}

In February 1807 Sidi Abdala Carcet 131 "of the Moroccan nation" sent a petition regarding an incident with a cargo of 2,817 fanegas of wheat and a load of barley from Arzew. He had been waiting for "four years and some months" for a definitive decision, which he believed was being delayed on purpose by the Admiral of Valencia, the ultimate authority as head of the appeals court

\footnotetext{
129 The Junta's members were José Pérez Caballero, Bernardo Febrer, Tomás Pérez de Parayuelos, Pedro Nicolás del Valle, and Antonio Ranz Romanillos; it announced its finding in Madrid on 8 October 1803. José de Godoy informed Pedro Ceballos of the decision: Madrid, 10 October 1803, A HN, Estado, leg. 5802.

130 Petition by Ali Turqui, dated in Madrid 12 October 1803. Signed in Arabic, AHN, Estado, leg. 5802 .

131 He is also called Abdala Tersi.
} 
(Audiencia) in that city. ${ }^{132}$ Carcet claimed to have imported the grain from Oran to Alicante in May 1801 in the Ragusan polacre Inmaculada Concepción under Captain Glavich. Two local merchants, Esteban Die and Ignacio Casson, had signed a contract with the captain in the name of the municipal government of Alicante: they would buy 2,80o fanegas of wheat at eighty-eight reales apiece, the captain would paying the cost of unloading, and the buyers would assume any other costs. But while the wheat was still being unloaded, several bakers complained of its poor quality. The local magistrate ordered it to be ground, baked, and sampled, after which both doctors and bakers proclaimed that it tasted and smelled bitter; Alicante's Board of Health ordered all the wheat returned to the ship. At that point Ragusa's consul, who had mediated in the sale, claimed that the buyers should pay for the reloading, while the buyers objected that since the Board of Health had disallowed the sale they had not actually bought anything. After the consul appealed, the grain was unloaded once more and stored in a warehouse; but local officials insisted it should be reloaded a second time and that the polacre should leave Spanish waters. The ship's captain named as his representative Abdala Carcef, a commissioner of the Bey's and the overseer of the port of Arzew, and Carcef asked the king for repayment of the grain and its associated costs.

Four months later "the Moor Caddur Massus, representing the Bey's son Siddi Jaqui Mahamet," appeared before the magistrate in Alicante and "present[ed] various documents showing that the grain that Captain Glavich had taken out of Alicante had been bought by the commissioner for wheat in Lisbon." Since the wheat had been of good quality, he was suing Casson and Die for 185,629 reales for damages and costs. ${ }^{133}$

This petition forced the Admiral of Valencia to resolve a matter that should have been settled long before: ${ }^{134}$ the appeals court in that city ruled immediately that its counterpart in Alicante and the Board of Health there had both acted incorrectly. The officials still insisted that the case had been handled as soon as possible, and criticized what they saw as the Moroccan's presumption: "I am amazed at the boldness with which the Moor Siddi Abadala Carcef has disturbed the king and Your Excellency in this matter, resulting in the sovereign's decision of the 7 th of this month."135

132 There is a discrepancy between his date of arrival, 1801, and the four-plus years he claimed in 1807: petition by Sidi Abdala Carcet, Alicante, 24 February 1807, AHN, Estado, leg. $5^{818}$ (the document is a draft).

133 Petition from Sidi Abdala Carcet, Alicante, 24 February 1807, AHN, Estado, leg. 5818.

134 Aranjuez to Capitán General de Valencia, 9 April 1807, AHN, Estado, leg. 5818.

135 Domingo Izquierdo to Pedro Ceballos, Valencia, 4 October 1807, AHN, Estado, leg. 5818. 


\subsubsection{Staibesel (1802)}

In 1802 Staibesel, 136 "a Moroccan Moor and relative of the king of Morocco, officer of a frigate, a native of Salé," was combining naval service to the sultan with commercial activities:

For purposes of his business he arrived in Barcelona on a royal schooner, and proceeded from there to Mahón where he bought a ship and chartered it with a load of Brazilian tobacco for Majorca. Unable to sell it there he set out for the port of Gibraltar, first obtaining the waybill and a passport from the port's administrator, signed by the scribes, as well as the deposit required in Gibraltar.

On leaving Majorca, however,

bad weather forced him into Tarragona, from which they let him depart on seeing his waybill. But as the bad weather continued he put into El Fangar, remaining for eight days. He presented the same documents to a xebec of the coast guard of Barcelona, stopping also at Los Alfaques.

But he continued to have trouble with his ship:

Having no cables or iron to anchor with he put into La Rápita for supplies, and there he was seized by the rent collector of Vinaroz, Don Josef Bernal, with his vessel. And though he showed him the legal assurances for his voyage and his legitimate papers [Bernal] took him to Vinaroz, where he stripped him of an arquebus, a long gun, a sabre, and two Moorish knives. He opened his chest and removed two hundred duros, two repeating watches, two exquisitely worked pairs of silver buckles, and four large kerchiefs, assuming it all to be contraband. He took him to Valencia, mistreating him in word and deed: he spat on his flag and his turban, put him in manacles, and ordered him served a tot of liquor to intoxicate him.

Forced to serve a quarantine in the port of Valencia, Staibesel was robbed on his last night of some of his tobacco:

The head administrator opened his pouch and took out a large amount of tobacco, allowing the sailors there to do the same and carry off as

136 Also called Estabesel. 
much as they wished, and they complied at once. Then he placed the petitioner in the San Narsi prison, leaving him without any means of communication, food, or money, with no more help than the four daily cuartos that are allowed to smugglers. And now briefs are being drawn up against him with no motive but the bad faith of the man who seized him, as is proved by his theft of tobacco before the brief, so as to claim that the petitioner sold the amount that will be missing from what is documented.

Staibesel claimed to be writing "from a sad and lamentable situation, disconsolate and almost dead from hunger"; he was forced by the "violence, malice, and ill treatment of the said officer to send this respectful appeal up to the feet of the Spanish monarch." He asked "for release from prison and the return of his ship, tobacco, money, and other effects unjustly seized by Don Josef Bernal, officer of the coast guard of Vinaroz, with restitution for all the damages he has caused him." 137

137 "[C]on motivo de su comercio, llegó a Barcelona con una Escuna de su Rey y de allí paso a Mahon donde compró un Barco, que fleto con cargo de Tabaco de Brasil para Mallorca, y no pudiéndolo vender lo dirigió a la plaza de Jibraltar, sacando antes la guía, y el pasaporte del General y Capitan del Puerto, con las firmas de los Escribanos, para segurar su viaje, dando asimismo la fianza responsiva de Jibraltar. ... [P]or mal tiempo se vio presisado arrimarse a Tarragona, y presentando su guia le dejaron ir; pero continuando el mal tiempo envistió en el Fangar; se detuvo ocho días, hizo la misma deligencia con el Javeque del Resguardo de Barcelona. Detuvose también en los Alfaques. ... [P]or no tener cables, ni Yerro para dar fondo, paso á la Rapita a proveerse, y le asaltó el Cabo de rentas de Vinaroz Dn. Josef Bernal con su falucon, y sin embargo que le hizo presente la seguridad de su viaje, y legitimidad de sus Papeles, se lo llevo a Vinaroz, y despojándolo de un Trabuco, un fuzil, un sable, y dos cuchillos morunos, le habrio el cofre y que quito Ducientos duros, dos reloxes de repiticion dos pares de hebillas de plata hechura exquisita, y Quatro pañuelos grandes, y suponiendo que era contrabando, lo condujo a Valencia maltratándole de palabra, y obra; pues le escupió la Bandera y Turbante, le puso grillos y mando una porción de aguardiente para en borracharle. ... [E]l Administrador General le habría una coracha y le quito una grande porsion de Tabaco, dando lugar a que los marineros que se hallavan presentes, hiziesen lo mismo y se llevasen quanto quisiesen, como efectivamente asi lo hegecutaron. Despues metió al Exponente en un calabozo de Sn. Narsy, dejandolle sin comunicación, sin comida, sin dinero, y sin mas socorro que los doze quartos diarios que se suministran a los contrabandistas: $y$ en el dia se le forman autos de oficio, sin otra prueba que la mala fee del que le prendió, puesta lo acredita la extracción del Tabaco que ha echo antes del manifiesto para atribuirle al Supte la venta del que falta a la cantidad que expresa la guía": Undated petition signed in Arabic, 1802, AHN, Estado, leg. 5807 , Exp. 5 . 


\subsubsection{Mahomet Bencherif(1807)}

The Moroccan brigantine Dib was seized off La Higuerita (now Isla Cristina) in March 1807 on the assumption that it (and its cargo) belonged to an enemy nation:

Having examined its documents closely I find that they offer sufficient reason for this suspicion. They should have been renewed during the period named in the royal decree (issued by the Minister of State on 18 July 1801, and communicated privately to this Admiralty on the 22nd following) concerning the manner in which Moroccans should travel. I observe that all [the documents] are earlier than that and therefore useless and incapable of legalizing his flag.

Besides, the report continued, only the captain was a Moroccan; the other crew members were four from the Austrian Empire (the first mate and three sailors), four Ragusans, and a Portuguese. Those did not agree with the passport from the Spanish consul in Tangier, which listed the crew as "four Moors including the captain and three Christians, among them a pilot, seven persons in all." In any case, both combinations contravened Article 2 of a decree from the Moroccan sultan that stipulated the muster of a Moroccan vessel: "the crew ought to consist entirely of Moors, without a single Christian." If all this were not enough to "prove the irregularity and fraud of this ship's journey," the Spanish consul's passport was dated 19 November 1787 , whereas the abovementioned royal decree invalidated all passports dated prior to 12 June $1801 .{ }^{138}$

Spain's consul in Tangier told the Secretary of State that he knew of the brigantine's detention, and had advised his vice consul at once "in case that government [of Morocco] should make any claims; though I think it will not do so for the present, because our procedures agree with their orders." It was

138 "Habiendo examinado atentamente los referidos documentos, encuentro que ellos dan motivo mui suficiente para esta sospecha, por que debiéndose haber renobado en la época que señala la real orden expedida por el Señor ministro de Estado en 18 de Julio de 1801 y comunicada a esta Capitania General por esa via Reservada en 22 sucesivo, relativa al modo en que los Marroquies deben hacer sus navegaciones, observo que todas son anteriores a ella, y por consiguiente inútiles é incapaces para lixitimar su bandera.... quatro Moros comprehendidos el Arraez, y de tres Christianos entre estos un Piloto, en todo siete personas. ... la Tripulacion debe componerse toda de Moros sin ningún Christiano." Underlining in the original. The report was based on two statements by the military adjutant of La Higuerita district: Juan Joaquín Moreno, Vice-Admiral of the Fleet and military governor of the Cádiz district, to Francisco Gil y Lemus, Isla de León, 2 March 1807. Nine days later Gil y Lemus informed Pedro Ceballos of the affair, AHN, Estado, leg. 5806. 
important, he said, to prevent Muley Sliman from intervening in such cases in the future, "since the captain alleges ignorance of the law, having been absent from his country since before it was issued"; that would be "very plausible and likely, in view of the informality and lack of consequence of that government." He proposed that, if it could not be proved beyond a doubt that the brigantine was "of enemy ownership," the captain be allowed to sell it in his place of detention. That would achieve two aims: to stop such ships from sailing illegally, and to prove once more to the Moroccans "His Majesty's sovereign generosity," for although the sultan had declared lawful the seizure and confiscation of those vessels, the king of Spain renounced that right to avoid the financial ruin of Moroccan subjects. ${ }^{139}$

The case of the brigantine was brought up for examination in August. In the presence of Ahaja Benifrien, "legal representative of Captain Mahomet Bencherif," all the documents and actions taken were reviewed and the ship was declared a legitimate prize. Bencherif was also ordered to pay damages for not having kept his documents complete and up to date: he was unable to present "the document that proves the ownership or purchase of thirty lead bars, the cargo certificate, the patent of navigation, or the list of crewmen." His passport from 1787 was no longer in force: "He cannot sail freely and openly without being exposed to the loss of the vessel and cargo and the penalties established by royal decrees, in accordance with rules established by the government of Morocco."

Still, things did not go badly for the captain and he was treated with some indulgence, which the court hoped would not set an example for other lawbreakers. Perhaps they could save him from even greater losses in the future, "so that he will not experience greater harm in his detention; and the Moroccan consul in Cádiz or any other respected person should be his guarantor."

In an interesting detail, the decision was announced to the captain's representative in the presence of "an agent of his nation in Cádiz, Jamet Almansor" - the translator whom we met above. ${ }^{140}$

But in October of that year an official at La Isla de León informed the Secretary of State that Captain Mahomet Bencherif was "sailing against all the established regulations, without documents that justify his ownership nor others

139 The consul was basing his arguments on a letter he had received the previous 24 March, though its sender and recipient were unknown. Antonio González Salmón to Secretary of State Pedro Ceballos, Tarifa, 7 April 1807, A HN, Estado, leg. 5806.

140 Summary made by Cristóbal González Téllez, military and naval scribe of Cádiz, based on a report dated 22 August 1807 by the naval adjutant and governor of La Higuerita. Dated in Isla del León, 25 September 1807, AHN, Estado, leg. 5806. 
that are absolutely necessary, and therefore under strong suspicion that his cargo and vessel are of enemy ownership."141

\subsubsection{Tajar Ben Majamet (18o8)}

Captain Tajar Ben Majamet, the Moroccan captain of the xebec Embarc, sued the French corsair La Cigogne under Captain Joseph Balvastre for the return of a load of wine he had been shipping from Tarragona to Cartagena. ${ }^{142}$ The French ship had captured the xebec off the Cabo de Palos and had taken it first into an anchorage called Genovés and then to the port of Alicante. The captain claimed that his wine was paid for by the Royal Treasury and intended to supply the royal fleet and its provisioners. His documents were false only because he feared being searched by English men-of-war. ${ }^{143}$

\subsubsection{Achay Candor Abbo (1810)}

This "Moroccan Moor," who lived in Ceuta with his wife and family, obtained a passport from the governor of that port for his business travels: "For several years he has been established in this port, leaving it for his trade in other commercial ports of the continent [of Europe] and the Kingdom of Portugal, always displaying the best conduct." He must have encountered occasional problems, for example in Cádiz in 1810, "with the object of reestablishing himself in the place of residence of his wife and her family, as is well known. And if necessary he will declare it fully and definitively, and that his absences are only temporary and related to business, while he always maintains that domicile."

He feared that his ability to travel for business would be curtailed: "Perhaps some barrier will be placed against his free and open comings and goings, with limits on the times for his trading expeditions; [so he does this] to avoid any impediment and in search of shelter and protection." He therefore asked the governor of Cádiz to return to him the passport he had to show on entering the port: "That he may consider expedited the passport that Your Majesty's governor gave him in the port of Ceuta, and issue the corresponding royal decree, so that he can leave and enter the port of Ceuta, where his wife and family live, by returning said passport to him."144

141 Francisco Gil y Lemus to Pedro Ceballos, San Lorenzo, 7 October 1807, AHN, Estado, leg. 5806 .

142 Joseph Betego to Pedro Ceballos, Alicante, 5 April 1808, AHN, Estado, leg. 5807.

143 Undated and unsigned report, probably destined for the governor of Alicante, 7 June 1808. A marginal note says it should be forwarded to the Ministry of the Navy: AHN, Estado, leg. 5807. See Guillén, Índice de los papeles, 129.

144 Signed in Arabic in Cádiz, 21 September 181O, AHN, Estado, leg. 5902. 


\subsubsection{Majamet Boali (1814-1815)}

In December 1814 Elja Selit Boali, "a Moroccan Moor," sent a petition to the Spanish monarch. His brother, who had lived for twelve years in Málaga and Cádiz, had met a violent death in the latter city:

His brother Majamet Voali was a trader in Spain for the last twelve years, having resided for a long time in Málaga where he was universally beloved for his good conduct. During the outbreak of plague in Cádiz, when he was at the height of his strength although sixty to seventy persons a day were dying, Majamet caught the infection and as a result his mind was affected: he came to believe that someone would kill him, and once or twice he fired a pistol from his window without hurting anyone. This would not have happened if the owner of the house had warned the Moors about his illness, for they were unaware of it. ${ }^{145}$

He went on to describe the "horrendous event that occurred to [his] unfortunate brother," with the involvement of a patrol of Cádiz Volunteers:

Seven or eight young men, armed volunteers of Cádiz, came to the door of the house where Majamet Voali lived. They knocked, and when he did not open they said they would break down the door; then he did open it and they murdered him, stabbing him treacherously in the back, then ransacked the house and stole all the money and valuables it contained.

When the news became known, local Moroccans - proving that there was a colony of North Africans in Cádiz - went to find his body:

The Moors learned of this incident and went immediately to recover his body, but their pleas were in vain, for Valdés told them that he would not

145 " [S] $\mathrm{u}$ hermano Majamet Voali, estaba comerciando en España de doce años a esta parte habiendo residido en Malaga largo tiempo querido de todos por su buen proceder: En tiempo de la Epidemia de Cadiz, y quando estaba en su mayor fuerza, falleciendo diariamente de 6 o a 70 personas fue Majamet tocado del contagio y de resultas quedo su cabeza trastornada, dando en la locura de que le iban a matar, y una ó dos veces desde su ventana disparó una Pistola al ayre, sin hacer daño a nadie, lo que no hubiera ejecutado, si el dueño de la casa hubiere avisado á los Moros su enfermedad, que la ignoraban": "Reclamacion del moro Marroqui Elja Selit Boali sobre la muerte y despojo de un hermano suyo vuelto loco en Cadiz de resultas de la epidemia," signed in Arabic, Madrid, 2 December 1814, AHN, Estado, leg. 5807. 
help them and they must leave. The atrocity did not end here (and the government tolerated it): they dragged his body out, spitting and urinating on it, then took it to the door of the jail where they committed the worst and most disgusting outrages upon it, unworthy of such a nation and of civilized people. And on whom did they inflict these atrocities? On a poor, insane Moor, when they would not do it to one of their citizens, and all out of their greed to rob him. Sir, to murder a mad person is the greatest act of barbarity and injustice.

Therefore the brother was appealing to King Ferdinand vII, calling him "the protector of the unfortunate" and arguing that "a Moor does not know the laws that are observed here":

In your government there are very strict laws against offending in word or deed any foreigner legally admitted by the government; and if these are broken the Emperor imposes a severe punishment depending on the gravity of the offense. And certainly a murder and robbery as scandalous as this one should receive the ultimate sentence, but here there has been no reproach of the guilty parties and the murderer is strolling through the streets of Cádiz with the utmost contempt for the law. ${ }^{146}$

Boali's "unfortunate family" had suffered "incalculable harm": "His eighty-sixyear-old mother, with six children, and another widowed sister with two, are

146 "Se presentaron á las Puertas de la Casa donde vivía Majamet Voali, de mano armada, siete ú ocho mozos voluntarios de Cadiz llamando, y no queriendo abrir dijeron romperían la Puerta, á esta resolución abrió, e inmediatamente lo asesinaron por detrás traidoramente, saquearon la casa robando el dinero y quanto precioso tenia.... Este acontecimiento fue savido de los Moros, e inmediatamente se presentaron para recoger el cadáber, y sus suplicas fueron inútiles, pues les respondió Valdés, que se fuesen si no les acomodava de aquel modo; no paró aquí la atrocidad, tolerada por el Gobierno: sacaron el cuerpo arrastrando escupiéndole, y orinándose en él, lo llevaron a la Puerta de la Carcel donde hicieron las mayores ignominias y asquerosidades impropias de tal Pueblo, y de gentes cultas ¿y con quien hicieron estas atrocidades? Con un pobre Moro, loco, que no lo harian con los Nacionales, y todo por la codicia de robarle: Sor asesinar a los Locos és la maor barbarie, é injusticia ... [E]n su Gobierno hay ordenes muy rigorosas para no ofender a ningún estrangero, qe tolera el Gobierno, de palabra, ni obra, si se quebrantan, castiga el Emperador con mucho rigor según la gravedad del exceso, y seguramente un asesinato y robo tan escandaloso como este seria escarmentado con el ultimo suplicio; y aquí ni una reprehensión se ha dado á los culpados pues el asesino se esta paseando por las calles de Cadiz con el mayor desprecio de la buena Justicia": Petition by Elja Selit Boali, 2 December 1814 . 
victims of misfortune: because the deceased handled all his family's affairs and was the support of them all, and they are now reduced to abject poverty."

The judge in charge of the case, Santacruz, on orders of Governor Valdés ${ }^{147}$ had arranged to sell "the household goods and furniture that had not been stolen for 440 duros, of which they kept half and gave the other half to his mother. But it is well known that in clothes and jewelry alone what she wore was worth more than two thousand duros, and this luxury indicates the wealth of the deceased Majamet, which has been entirely concealed."

The petitioner "speaks the truth and trusts in the rectitude of Your Majesty." Significantly, he had first intended to appeal to Napoleon himself: "Although he was determined to present his complaint to his Emperor, after learning that Your Majesty was restored to the throne of his forebears he comes to the foot of your throne and implores your justice." Numerous Spaniards had found refuge in Morocco during the recent Napoleonic wars: "Since many Spaniards have been exiled in Barbary during this war, and some live free of oppression or ill treatment while enjoying the greatest hospitality, it would be a scandal in those realms, and of great moment, if this atrocity were not punished."

He therefore begged for a review of the case and a fairer sentence:

Let everything done in Judge Santacruz's court in Cádiz be collected in its original form and sent to Madrid so that, once it is read and absorbed by whomever Your Majesty wishes to designate, a more useful and opportune decision be emitted, for the punishment of the guilty and satisfaction of the Moors who have acted, as is well known, with firm adherence to Your Majesty and your just cause, favoring this disconsolate family with whatever recompense Your Majesty sees fit. ${ }^{148}$

The Secretariat of State sought information from the governor of Cádiz, who replied that "in the actions he saw there had been no sign of theft of the deceased Moor's goods or of the insults made to his corpse, which his brother the

147 The governor at the time, Cayetano Valdés, and Judge Santacruz were of liberal ideas and had suffered reprisals from Ferdinand vir. The petition's author was trying to gain the sympathy of the absolutist monarch.

148 “...mandar recoger y remitir a esta Corte, integro y original todo lo actuado en el Juzgado del Juez Santa Cruz en Cadiz, para que visto y reconocido por personas que V. M. tenga a bien comisionar se dicte la resolución mas útil y oportuna, para escarmiento de los culpados y sastisfaccion de los Moros que se han portado, como es notorio, con la decidida adhesión a V. M. y su justa causa; agraciando a esta desconsolada familia con la recompensa que sea del agrado de V. M.": Petition by Elja Selit Boali, 2 December 1814, AHN, Estado, leg. 5807 . 
petitioner has assumed."149 But the matter was not entirely settled, since the governor had to intervene again a year later, in a meeting with the local military judge advocate, regarding the affair of "the Moors Elja Selit Boali and Brahim." After reviewing the briefs in the case of the Moroccan's death he found nothing irregular: "Having looked over the first document I saw that it was merely the inventory of Majamet Voali's goods, and that [his brother's] complaint extended also to those who caused his death, about whom there was a military report because they belonged to the urban militia." He had also consulted the Sergeant Major of the Cádiz Volunteers, though he was not able to examine the case of the "Moor Brahim," so we do not know what weight it might have been given. On the previous day the military scribe had shown him two dispatches from the Supreme Council of War that requested "resubmission of the original briefs because of a new complaint by the Moors to His Majesty," and he had complied at once. He also sent the Secretary of State two statements by Boali and Brahim. In spite of his inability to examine all the evidence, however, he maintained his firm conviction that nothing in the confirmation of the case had fallen outside the norm:

With respect to the inventory of the Moor Boali, there is no defect in its confirmation. The procedures were unusually long and costly because they investigated whether the deceased had deposited monies with a man from Santander who lived next to the Café del Correo, since that was mentioned in a statement from the consul in Tangier. There is no indication in the evidence of the military tribunal, nor of the mayor Don Joaquín de Villanueva (who was the first to oversee the retrieval of the Moor's body and securing of his goods), of that appropriation or theft of his goods nor the supposed insults to his corpse; only that it was taken to the door of the jail. 150

149 Note from the Palace, 12 December 1814, with a summary of Boali's petition attached. Another similar report of 8 March 1815, AHN, Estado, leg. 5807 .

150 "[P]or lo respectivo al inventario del Moro Boali que no se nota defecto en la sustanciación, y que las actuaciones fueron mas largas y costosas por haber apurado la especie de si el difunto tenia dineros depositados en un Montañez inmediato al Café del Correo por haberlo indicado asi en un oficio el Consul de Tanger, no resultando de las actuaciones del juzgado de guerra, ni en las del Alcalde Constitucional Don Joaquin de Villanueba que fue quien practico las primeras diligencias de recoger y reconocer el cadáver del Moro, y asegurar sus bienes, ni la extracción ó saqueo de estos ni el ludibrio que se supone haber hecho del cadáver del Moro, sino solo que se llevó a la Puerta de la cárcel": Count de la Bisbal to Secretary of State, Cádiz, 12 February 1815, AHN, Estado, leg. 5807. 


\subsection{Algerian, Tunisian, and Tripolitan Captains, Pursers, and Merchants}

We have mentioned several times that in the years between 1782 and 1791 Spain established permanent peaceful relations with the Ottoman Empire and the North African regencies. ${ }^{151}$ These agreements - essentially the same as the ones with Morocco - allowed ships and merchants of those countries to enter Spanish ports. Just as in the Moroccan case, however, their presence was scarce in the early years, as we saw in Table 6 . Good-faith efforts were made to foment direct trade between both sides, resulting in ever-increasing imports of Maghrebi cereals into Spain; these were paid for in silver coin, as we showed in Chapter 5 , Section $5 \cdot 3$.

The little information we have about other North African merchants confirms that they appeared in Spain later than the Moroccans did. In 1791 in Barcelona, a Tunisian purser arrived to oversee a cargo of wheat that had been loaded in Susa onto a Ragusan ship. ${ }^{152}$ In 1792 the governor of Málaga, wishing to learn how best to connect his port to Tunis, was able to consult two traders, one from Tunis and one from Algiers, who informed him that communication with Alicante was much easier. ${ }^{153}$ Contacts had increased by the early nineteenth century, and as with the Moroccans, very few of the men involved caused any problems.

The prime mover of North African traders' presence and activity in Spanish ports proved to be Spain's wars with France and England. Especially after 1797, Algerian and Tunisian ships and pursers took an active part in shipping products between Spain and North Africa and in coastal trade in Spain itself. Many of these voyages were short and some involved only brief layovers for repairs. It is sometimes difficult to distinguish between corsairs and traders, since the former also engaged in commerce. We will speak here of only a very small portion of all the merchants from the Central and Eastern Maghreb who visited Spanish soil.

$15^{1}$ The treaties with the Bey of Tripoli, the Dey of Algiers, and the Bey of Tunis were all very similar. See their complete texts in Cantillo, Tratados, convenios. Also Conrotte, España y los países musulmanes.

$15^{2}$ In a ship captained by Pedro Genbich: IMHв, Fs, Serie X, caja 12, with a patent dated 3 October 1791. Dozens of North African pursers have been identified and documented in different Spanish ports.

153 Arribas Palau, "Nuevos datos sobre moros en la Alhambra." 


\subsubsection{Ben Talb (1786)}

Ben Talb, an Algerian, arrived in Cádiz from Algiers in an English brigantine loaded with cotton and silk cloth originally from Smyrna. Since he had not served any quarantine he was not allowed into port, so he chartered a small boat in Valencia and took his goods to Tangier. ${ }^{154}$ The European consuls there, who were empowered to review the health documents of ships that entered the port, advised the Algerian to proceed to the lazzaretto in Marseille and serve his quarantine there. But Ben Talb, "with excessive pride" by the Spanish consul's account, appealed to the sultan, who authorized him to unload the cargo in Tetouan. Later, however, after the sultan received reports from the consuls and the governor of Tangier, he revoked that permission and ordered the ship to Marseille. In the Spanish consul's opinion, "the Moor Ben Talb is not very truthful; I know that he blamed the Spanish consul when his goods were not admitted into Tetouan, while in fact mine was only one vote among all those who wished to deny him entry." He added, "I have no doubt that when this Moor returns to Algiers he will complain about us to the Dey, if he has not already done so in writing." 155

\subsubsection{Youssef el Tripolino (1786)}

Our first notice of this captain comes in March 1786, when the sultan of Morocco announced that he was in Cádiz to charter an English vessel; he would load it with Moroccan wheat bound for Tripoli. ${ }^{156}$ Shortly afterward Spain's consul in Tangier reported having received a letter from Robert White Fleming, who was settled in Cádiz, with news of Youssef's death:

He tells me of having sent, in a Spanish brigantine to the port of Mogador around August last, six thousand pesos fuertes in cash and nine hundred ninety-eight hides from Buenos Aires, entrusted to a Tripolitan Moor resident in Mogador by another Moroccan who is in Cádiz. And by chance, as the brigantine arrived the Moor from Tripoli died.

The sultan ordered the Tripolitan's goods to be confiscated, including the six thousand pesos and the 998 hides. Robert Fleming's attempts to recover them

\footnotetext{
154 Note added to a letter, J.M. González Salmón to Count Floridablanca, Darbeyda, 3 January 1786, AHN, Estado, leg. 4319.

155 J.M. González Salmón to Count Floridablanca, Darbeyda, 3 January 1786, AHN, Estado, leg. 4319 .

156 Copy of letter from His Moroccan Majesty to J.M. González Salmón, 1 March 1786, AHN, Estado, leg. 4319 .
} 
failed, though he worked through several merchants in Mogador after learning that by the sultan's order the money and hides had been sent to Tripoli and given to Youssef's family. At Fleming's urging, the Spanish consul asked the sultan to return the merchandise, and the sultan agreed even though

he does not want Spanish merchants to hand over their funds to unknown persons and outsiders, but to those with a claim on them who are his vassals; in this case His Majesty trusts them, and our people will run no risk. Therefore I have sent notice of this favor to trusted men in the ports of Mogador, Larache, Tangier, and Tetouan so that they may announce it to all Spaniards who arrive there, and in this case I will also inform the governor of Cádiz so that he can tell the merchant colony there. ${ }^{157}$

The sultan had also decided to make the consul the receiver of "what the Tripolitan left, down to the last cent," in accordance with the Spanish-Moroccan Treaty of Peace; "and though persons from other Christian nations may make some claim to those goods, pay them no heed and surrender everything to the Spanish Consul."158

In yet another letter the sultan insisted again that if creditors "of other nations" appeared they must wait for Spaniards to collect their debts first. He scolded the consul for not having abided by the appropriate article of the Treaty of 1767 , on the disposition of the property of Moroccans who died in Spain:

Spanish merchants have been entrusting their estates to a foreigner or outsider. Many times we have warned against doing this, and have written that estates must be given only to persons who are known and are our vassals. Because if they come from our domains and you give them estates

157 "[M]e refiere haver enviado en un Bergantin Español al Puerto de Mogador por agosto pasado Seis mil Pesos Fuertes efectivos y Nuevecientos noventa y ocho cueros de Buenos Aires consignados a un Moro Tripolino residente en Mogador por otro Marroqui que se halla en Cadiz, y que dando la casualidad que á la llegada del Bergantin falleció el Moro tripolino. ... [N]o quiere que los Comerciantes Españoles entreguen sus Caudales a sujetos desconocidos, y forasteros, si no a los abonados y que sean sus Vasallos pues en este caso S.M. los fia, y no correrán riesgo los Nuestros; por lo que me ha parecido conveniente pasar aviso de esta providencia à los Confidentes en los Puertos de Mogador, Larache, Tanger y Tetuan para que la hagan saver à todos los Españoles que concurren en cada uno, y también lo avisaré en esta ocasion al Governador de Cadiz para que lo notifique a aquel Comercio": J.M. González Salmón to Count Floridablanca, Darbeyda, 5 June 1786, AHN, Estado, leg. 4319 .

$15^{8}$ Translated letter from His Moroccan Majesty ("by the King's hand”), A HN, Estado, leg. 4319. 
we guarantee them; but with one like this outsider and unknown figure in our domains, what would you have done if his property had been lost or wasted? Spanish merchants will lose it. And we now instruct you to write to Cádiz and elsewhere so that no other such thing will happen. ${ }^{159}$

The governor of Mogador and Tahir Fannis handed the Tripolitan's goods over to the consul, but "since it is much more than what belongs to Don Roberto White Fleming of the merchant colony of Cádiz, I must request His Majesty to tell me to whom the excess should be given, so as to be done with this affair."160

\subsubsection{Mahamet Ben Seitun (179o)}

In June 179o Spain's consul in Morocco reported from Cádiz that a "Moor from Tripoli" had come before him:

Mahamet Ben Seitun ... comes from Tangier with a letter from my brother the vice consul. His Moroccan Majesty recommends him so that the king our master will intervene with his august brother the king of Naples, and help the Moor in a case he has in that court. He seeks the value of a shipment of timber that was confiscated in Sicily by the consul of His Sicilian Majesty.

The consul tried to do his best for him:

I offered him a letter for our minister in Naples and help in reaching that court by paying his passage as far as Genoa. And though at first he agreed and was satisfied, he later changed his mind and wants to go to [Madrid] to tell Your Excellency in person of his hopes, and to collect a recommendation for the court in Naples.

159 "[E]sta cosa que han hecho los Comerciantes Españoles de entregar sus caudales a un desconocido, y forastero, quantas vezes hemos prevenido que no se haga, y hemos escrito que no se entreguen Caudales, sino a los conocidos, y Nuestros Vasallos; por que si son de nuestros Dominios, y les entregáis Caudales, Nosotros lo fiamos; pero uno semejante á este forastero, y desconocido en Nuestros Dominios como hicierais si los Caudales se hubieran desaparecido o mal gastado? Lo perderan los Comerciantes españoles; y nosotros ahora te mandamos que escribas a Cadiz, y á otras partes para que no suceda otro caso semejante": Translated letter to J.M. González Salmón, 23 May 1786, AHN, Estado, leg. 4319.

160 J.M. González Salmón to Count Floridablanca, Darbeyda, 25 June 1786, AHN, Estado, leg. 4319 . 
At the same time, however, the consul assured the Secretary of State that he would try to dissuade the petitioner from traveling to Madrid "to disturb Your Excellency" 161 He was unsuccessful, as the Tripolitan insisted on setting out for the capital in spite of many difficulties:

\begin{abstract}
He has not yet left here for lack of a coach, and I send Your Excellency this news in advance by today's post so that when the Tripolitan arrives there he will soon find the letter of recommendation he requests for the court in Naples, if Your Excellency is pleased to give it to him. With that you will avoid the annoyance that this type of people create when they tarry there. ${ }^{162}$
\end{abstract}

A note on the cover of the file states that Ben Seitun found no help in Malta or Naples, and therefore requested a recommendation for the Neapolitan court. He claimed to have served under Captain Baxa Hassan and to have stopped off in Tangier. ${ }^{163}$ In fact Spain was in no way involved in his enterprise, since there was a charter contract signed in Malta to load a Neapolitan ship with timber bound for Tripoli. In the end authorities on the island confiscated the cargo on the pretext that it was contraband, and when Ben Seitun protested there he

161 "Mahamet Ben Seitun ... viene de Tanger con una carta del Vize Consul mi hermano en que me dize se lo recomienda S. M. M. para que el Rey Nuestro Señor se interese con su Augusto hermano el Rey de Napoles a fin de que se atienda la solicitud que tiene en aquella Corte dicho Moro que se dirije a que se le devuelva el valor de un cargamento de madera que se le confisco en Malta por el Consul de S. M. Siciliana. ... [L]e ofreci carta para el Ministro de Napoles, y ponerle en aquella Corte, proporcionándole pasage de aquí a Genova, y aunque de pronto condescendió y le pareció bien, después ha variado y quiere ir a essa para informar a V.E. individualmente de la pretensión que tiene y recoger la recomendación que solicita para la corte de Napoles": J.M. González Salmón to Count Floridablanca, Cádiz, 12 June 179o, AHN, Estado, 4316.

162 "[A] un no ha salido de aquí por falta de Carruage, y delanto a V. E. esta noticia por el Correo de oy para que quando llegue ahí el Tripolino pueda hallar pronta la carta de recomendación que solicita para la Corte de Napoles, si V. E. tiene a bien dársela, y con esto se exime de la incomodidad que ocasiona esta clase de gente si se demoran ahí": J.M. González Salmón to Count Floridablanca, Cádiz, 14 June 179o, AHN, Estado, leg. 4316.

163 There is a copy of his letter in Italian: "[C]he tempo fa essento ffato á Malta per mio comercio, ivi col mezzo del console delle Sicilie noleggiai un Bastimento Napolitano con patto di portarlo al luogo detto Feyum caricarlo di legname e di la rittornare addrittura in Tripoli sensa piu toccare á Malta, ed adderendo il Subt ${ }^{\circ}$ Capino a qesti patti in presenza del dto console egli mi passo il corrispondente contratto di Noleggio, ma in vece di tener questa sua promesa dopo aer io caricato el dto legname Egli senya necessitá ma per forza volle intrar in Malta ove daccordo col do console mi fecer aspettare sei mesi": J.M. González Salmón to Count Floridablanca, Cádiz, 14 June 179o, AHN, Estado, leg. 4322. 
was told to take his complaint to Naples. The consul, aware that the Tripolitan had been recommended by the recently deceased Muley Muhammad Abadallah, thought he should be "helped with his petition in the best way possible."164

The last we know of Mahamet Ben Seitun is that in July 1790 he asked for "funds to travel to Barcelona in a coach that will leave tomorrow night the 24th," for which he was granted six hundred reales. ${ }^{165} \mathrm{He}$ seems to have changed his plans and have traveled to Naples. ${ }^{166}$

\subsubsection{Aggi Yunis Ben Yunis (1799-1804)}

In June 1799 a corsair ship arrived in Barcelona carrying "Señor Aggi Junes Ben Junes, Commissioner of His Excellency Ameida Baxà [Pasha], Bey of Tunis." Later, in July, we find Aggi Ben Yunis in command of a Tunisian ship belonging to Soliman Rais that came from Tunis loaded with five hundred cahices of wheat imported by Valentín Riera and Company. ${ }^{167}$ In February 1804 he returned to Barcelona with a fellow Tunisian merchant, Mustafa Sfax; on their own initiative they had brought 139 jars of oil, 340 cahices of wheat, and 150 cahices of barley. ${ }^{168}$

\subsubsection{Mahamet Arrizzi (180o)}

Mahamet Arrizzi el Rassai, a Tunisian purser in charge of a cargo of grain, reached Barcelona in 1800 aboard the Ragusan brigantine Sacra Familia under Captain Nicolas Tommasich. His son Agi Aberraman Emerbricon, with the same position and cargo, arrived also, in the Ragusan polacre Minerva under Captain Natala Brailli; both were accompanied by servants. They requested permission to unload, and the consul of Portugal in Barcelona and designee of the cargoes, Jaime Romanyá, intervened so that their ships could be unloaded and they could serve the quarantine on land. They were then allowed to enter the port. ${ }^{169}$

164 J.M. González Salmón to Count Floridablanca, Cádiz, 16 June 179o, AHN, Estado, leg. 4322.

165 Note on the cover of his file, J.M. González Salmón to Count Floridablanca, Cádiz, 14 July 1790, AHN, Estado, leg. 4322.

166 Madrid, to Juan Acton in Naples, 18 July 179o, recommending the Tripolitan: AHN, Estado, leg. 4316.

167 Diario de Barcelona, 21 June and 2 July 1799.

168 Yunis Ben Yunis frequented the Spanish ports of Palma de Mallorca (where he had an agent), Barcelona, and Alicante: Panzac, Les corsaires barbaresques, 134, 157-58, 193-97, 205, 209, 211.

169 The consul presented a petition dated 12 July 1800, IM HB, FS, Serie I, leg. 22, fols. 86-88, Marquis of Vallesantoro to Pedro Molet, 5 and 17 July 180o. They were admitted to port on 16 July 1800 . 


\subsubsection{Captain Hadgi Zayton (180o)}

This Algerian captain came to Barcelona in 1800 commanding his frigate Compañia with six hundred bales of cotton. The prominent local merchant Francisco Gomis asked the city's health authorities to allow the bales into the lazzaretto, since the war between Algiers and France had put the cargo in danger. ${ }^{170}$

\subsubsection{Soliman Ben Yunis (1801)}

In 1801 the Tunisian Regency's Keeper of the Seal interceded on behalf of his servant Soliman Ben Yunis, who had arrived in Barcelona to buy "some pieces of silver work he needs." Specifically he asked that Soliman be allowed to serve the quarantine on land, so as to speak more easily with the silversmiths and "give them instructions about the forms that they [Tunisians] prefer."171

\subsubsection{Caddur Ben Massus and Abdalá Karsis (1802)}

These two men, ${ }^{172}$ who claimed to be representatives of the Bey of Algiers and the military governor of the port of Oran, asked in September 1802 to place a message from their masters directly into the hands of the Secretary of State; for this they would need a passport to travel to Madrid. The governor of Alicante made no objection but left the decision to the Secretary, "if you see fit to give them the attached passport." ${ }^{173}$

Once in Madrid they presented new information about the reason for their journey. They were "commissioners of the Dey and the Captain of the port of Arzew, and agents of Mahomet Ben Brain, Captain of the port of Oran, and of the Ragusan Captain Juan Glavich of the polacre La Purissima Concepción," and they had come to complain of "the proceedings of the Board of Health of Alicante related to a considerable shipment of grain seized from the Ragusan Captain Juan Glavich." Specifically, the board had pronounced on a quantity of wheat contracted with that captain:

170 The cotton had been seized ten months before by an Algerian corsair out of an imperial frigate bound for London. It was acquired by an agent of Gomis and sent to Barcelona by the commercial firm Joseph Cohen Bacri, one of the largest in Algiers: report by Francisco Gomis, 5 June 180o, Імн в, Fs, Serie I, leg. 22, fols. 74, 78, 11 June 180o: Baron Sarrahí to municipal Board of Health; Jacinto Sendil to municipal Board of Health, 6 June 1800.

171 Letter from Spain's consul in Tunis, Arnoldo Soler, recommending Soliman Yunis, who arrived in a Ragusan polacre under Captain Luca Claich, 28 March 1801. He was allowed to spend the quarantine in a warehouse by the city walls: Імнв, FS, Serie I, leg. 23, fols. $62-64 ; 24,26$, and 28 March 1801 . We do not know if he was related to Yunis Ben Yunis.

172 Abadalá Karsis also appears as Abdalá Carcef.

173 Petition dated in Alicante on 3July 1802, with their two signatures in Arabic: AHN, Estado, leg. 5804 . 
Once the wheat had been contracted for in good faith on the basis of a sample, all the resulting actions and risks belonged to the buyer, which had been the municipality and its commissioners. Further, even when a solemnly signed and concluded contract might be questioned, it should never be the case that the issue be decided by the Board of Health of Alicante, because its members, and even the governor who is its president, are interested parties in the suit; those individuals are officials of the municipality that agreed on the purchase and by whose order it was made. Therefore impartial judges will need to be named.

The petitioners hoped that the Secretary of State would

free these foreigners from lawsuits - as they are detained here by force with their grain which they were shipping elsewhere - by ordering that they be paid immediately the contracted price together with damages. And they believe that since there is a solemn, perfect, and unimpeachable contract, this action is the one most befitting the principle of the civil rights of persons in contracts, for if these are made in good faith there should be no issue with their fulfillment. Nevertheless they have learned that the sovereign rectitude of Your Majesty asked the head of your Council to decide the matter.

But just when they trusted that the decision would be in their favor and they would avoid "the delays, costs, lawsuits, and irreparable damages they are suffering because of this seizure of both their merchandise and their persons, they now find that your governor has ordered them to appear before the governor of Alicante that he may hear and decide the matter by sending it to the appeals court in Valencia.

The Algerians, speaking only in "the language of laws and the law itself," believed that the case had been given to "the most biased judge they could imagine." They pointed out that the governor, in his capacity as the chief officer of the city and president of the local Board of Health, had ordered the ship seized and its cargo sold in order to supply the city. They begged the monarch to bear in mind "the nature of the affair, and the common principles of natural law that require observance and good faith." They therefore asked that "at least the case be remanded to an impartial judge or judges, who may decide it briefly and summarily without contributing to any increase in damages." ${ }^{174}$

174 "[U]na vez contratado el trigo de buena fé, u bajo muestra, todas las resultas, y peligros eran del Comprador que lo había sido el Ayuntamiento, y sus Comisionados, y por otra, 
Abdalá Karsis must be the merchant whom documents from Málaga refer to as Sidi Abdala Kersif, a Moroccan. He was engaged there in importing North African wheat in partnership with an important local tradesman, José de Cuevas: around 1802 they brought in several cargoes of wheat from Algeria and Morocco. Cuevas's wife Antonia López, also a resident of Málaga and empowered to administer the affairs of both men, had sued Abdala Karsis in the Tribunal of the Royal Consulate; it had to do with collecting interest owed to Cuevas on several cargoes of wheat and barley that the men had delivered to different ports. The Tribunal ruled that the sum be paid to Antonia, but that she in turn must pay 27,486 reales de vellón, the true amount of her husband's debt; also, she had to settle all accounts with Karsis in Alicante. To that end Antonia pledged "her current and future assets and income and those of her husband."175

\subsubsection{Haggi Hamet Arcandi (1802)}

The Tunisian merchant Haggi Hamet Arcandi, with an interpreter named Pedro Barcelona and Captain Luca Claich of the Ragusan polacre La Madonna de

que aun quando el asunto en el cumplimiento de un contrato solemne, y concluido pudiese admitir conocimientos, nunca seria dable que estos fuesen en la Junta de Sanidad de Alicante por ser sus Yndividuos, incluso el Governador su Presidente interesados en el Pleito, como que los mismos son individuos de Ayuntamiento que acordaron la compra, y por cuya comisión se hizo, por lo que se hacia necesario el nombramiento de Jueces imparciales ... [L]os hubiese libertado de pleitos a unos extranjeros detenidos por fuerza con sus granos que llevaban a otra parte, mandando se les pagase inmediatamente el precio contratado con los perjuicios, y por parecerles que este temperamento habiendo como hay un contrato solemne, y perfecto, e indudable, es el mas propio de los principios del derecho de gentes, y del civil en los contratos, como que echos a buen fé solo debe tratarse de su cumplimiento: Pero sin embargo de esto han sabido que la soberana rectitud de V.M. embió su recurso al vuestro Governador del Consejo para que determinase sobre el particular": Petition dated in Madrid, 18 September 1802, AHN, Estado, leg. 5804.

175 "Pledge given by Antonia López, wife of José de Cuevas, before the Consular Tribunal. [Cuevas] is absent and his whereabouts are unknown. He was pursuing lawsuits against Cide Abdala Kersif, a Moroccan, to recover the interest on several cargoes of wheat and barley shipped by both of them, and for [Kersif] to pay him the 18, ooo reales that the Moroccan gave to Juan Barrera as the mortgage on a house in El Cañuelo de San Bernardo" ("Fianza que hace ante el Tribunal del Consulado Antonia López, mujer de José de Cuevas, ausente sin saberse su paradero y que seguía autos contra Cide Abdala Kersif, marroquino, sobre la cobranza de interés por varios cargamentos de trigo y cebada dirigidos por cuenta de ambos y para que le pague los 18.000 reales que el marroquino entregó a Juan Barrera hipotecando una casa en el Cañuelo de San Bernardo.") The text refers to business dealings by both men in Alicante and mentions names of other merchants including J.B. Maury and Nicolás Savalle [?]. Archivo Provincial de Málaga, Real Consulado de Málaga. Registro de Escrituras (1797-1807), scribe Andrés Albelda, leg. 3478, fols. 56-59, 15 October 1802 . 
la Salud, appeared before the Tribunal of the Commercial Consulate of Barcelona in May 1802. ${ }^{176}$ The Tunisian filed suit against the Ragusan, whose ship's papers were seized. The captain protested: he would be unable to unload his merchandise at its destination, Vilanova i la Geltrú, and both ship and cargo would suffer damage. He asked that Arcandi be forced to make a deposit of five hundred pesos fuertes against possible costs. ${ }^{177}$ The parties soon agreed to lift the embargo, though the "Moor" would have to pay 715 pesos fuertes. ${ }^{178}$ To honor the agreement the Tunisian offered the Ragusan captain 650 Roman scudi that he had left in Civitavecchia; Juan Bottoni of Rome would surrender them to whomever brought him the proper authorization. To that amount would be added another eighteen scudi for loading a shipment of timber the Tunisian would buy. The captain, for his part, promised to pay Hamet Arcandi 715 pesos fuertes in Spanish coin as the equivalent of those 668 scudi. ${ }^{179}$ The Tunisian agreed that, as a precaution, the amount would remain on deposit with Antonio Buenaventura Gassó and Company until the transfer in Civitavecchia was confirmed:

Because we have notice that the Tunisian had issued a letter of exchange for that amount through the house of Stembor and Company, who would pay it in this [city] as soon as it is satisfied there. Therefore, if the amount were collected in Civitavecchia or Rome on the Tunisian's behalf, the money deposited here should be returned to Captain Claich. And if, on the contrary, it should be at the captain's disposal there, the deposit made here shall be at the Tunisian's disposal; he too can collect it if it is confirmed that the said letter of exchange has been satisfied. Both men signed this. ${ }^{180}$

${ }_{17} 6$ In the same document the Tunisian is also called Achmet Alcasari, Sidi Achmet Alcasari, and Hamet Arcancani.

177 The scribe Francisco Roquer y Simón signed the document in Barcelona, 13 May 1802. Fondos de la Junta de Comercio de Barcelona, exp. 2227, Biblioteca de Catalunya.

178 Francisco Roquer y Simón, 11 June 1802. Fondos de la Junta de Comercio, exp. 2227, Biblioteca de Catalunya.

179 Recipt in which the Tunisian acknowedged having received the amount, signed in Arabic, Barcelona, 12 June 1802, Fondos de la Junta de Comercio, exp. 2227, Biblioteca de Catalunya.

180 "[P]or tenerse noticia de aver el tunecino librado una Letra de Cambio por dicho dinero por medio de la Casa de Stembor y $\mathrm{C}^{\mathrm{a}}$ quienes se la pagarían en esta luego que esté allí satisfecha, de modo que si se hubiese cobrado en Civitavecchia, o Roma por parte del tunecino, deberá devolverse al capitán Claich el dinero que aquí se deposita, y si al contrario quedase allí libre disposicion del Capitan quedara el depósito echo en esta Plaza a la disposición de tunecino, quien podrá también cobrarlo siempre que se 
In consequence the hold placed on Captain Claich's papers on 17 May 1802 was lifted, and on the same day 715 pesos fuertes were deposited with the firm of Antonio Buenaventura Gassó. ${ }^{181}$

\subsubsection{Captain Aggi Abdallah (1806)}

Certain Tunisian captains had relationships of greater or lesser intensity with merchants of Barcelona. In 1806 Captain Aggi Abdalla placed a notice in the local press that anyone wishing to travel to Tunis or ship merchandise there should deal with his "co-signer," Gervasio Gironela. ${ }^{182}$

\subsubsection{Captain Mahamet Ben Mocessa (1806-1807)}

This Algerian sailed from Algiers on 3 December 1806 in command of the polacre Embarck and arrived in Barcelona on 24 January 1807. He brought a cargo of used copper and sponges, the latter considered susceptible to contagion. After unloading part of his shipment and five Algerian passengers in the lazzaretto, he went on to Marseille where he was forced to serve a quarantine of twentyeight days. There he declared that he had stopped in Mataró before reaching Barcelona and in Palamós afterward. After an eighteen-day quarantine in the latter port he was allowed to enter it. The Marseille authorities held that in neither of those places had he fulfilled the complete health requirements. ${ }^{183}$

\subsubsection{Captain Amet Ben Mustafa (1807-1808)}

We already met this individual in Chapter 7. In December 1807 the Algerian captain Amet Ben Mustafa reached Tarragona after seventeen days' sailing. He was in command of the polacre Mesahoda of 1,500 quintales, and carried 410 Algerian quintales of dried cod and four barrels of sardines, all bought in Algiers. His papers confirmed that he had served nine days of quarantine in Peñíscola and had also stopped in Los Alfaques. He appealed to the governor of Tarragona, "as if you were my consul," because

justifique que la citada Letra de Cambio ha sido satisfecha. Ambos lo firmaron": F. Roquer y Simón, Barcelona, 18 June 1802. Fondos de la Junta de Comercio, exp. 2227, Biblioteca de Catalunya.

181 F. Roquer y Simón, Barcelona, 18 June 1802: receipt from Buenaventura y Gassó, Barcelona, 18 June 1802, Fondos de la Junta de Comercio, exp. 2227, Biblioteca de Catalunya.

182 Diario de Barcelona, 20 June 1806.

183 Marseille Board of Health to Junta de Sanidad, 27 February 1807, IM HB, FS, Serie I, leg. 28, fol. 93 . 
in the five days we have spent at anchor in this port we have still not managed to enter nor received any response; in this same night we received the reply from the captain of the port [saying] that you ordered us to go to Barcelona to complete the quarantine. I hope that of your goodness you will admit us to this port, because otherwise it will cause me great harm and delay. You must be aware that I have come from that [port] on purpose to load and unload in this one. ${ }^{184}$

On the captain's arrival in Tarragona he had been informed that health regulations required every ship coming to Catalonia to proceed first to Barcelona, the only port in the region equipped to receive vessels from North Africa; once admitted there he could proceed to any other Catalan port. The captain protested and refused to leave for Barcelona, claiming that he would rather see his ship go to the bottom. The health authorities consulted their superiors about whether they should use force, though making clear they they did not wish to "out of respect for humanity." Ben Mustafa was told, therefore, that if he served a strict quarantine on the spot he would be allowed to unload his goods and load a fresh cargo, but without official entry. ${ }^{185}$ Prudently, the captain presented a new appeal that explained his motives for not wanting to sail to Barcelona:

We are at war with three powers, the Portuguese, Tunisians, and Sardinians, and I am informed that two Sardinian corsairs are lying in wait for me between this port and that one. Besides, if an Englishman caught me going from one enemy port to another he would take my ship and cargo as a legitimate prize. If I leave here for there the loss of my ship and cargo is inevitable, and perhaps of my life and that of my crew as well.

184 Captain Amet Ben Mustafa's petition was composed by the ship's scribe, Juan Bautista Renelly, and was addressed to the governor of the port of Tarragona: Puerto de Tarragona, 9 December 1807, Iм Hв, FS, Serie I, leg. 28, fols. 146-48.

185 Count of Santa Clara to Marquis of Valle Santoro, 22 December 1807; Ignacio Correa to Count Santa Clara, Tarragona, 11 December 1807; Ramón Ansotegui, Board of Health, to Pedro Ignacio Correa, Tarragona, 11 December 1807, IмнB, FS, Serie I, leg. 28, fols. $146-48$. 
His fear was palpable. Everything suggests that he was sailing under a false flag, probably Spain's; though the captain claimed to be the ship's owner, its only crew beside himself consisted of ten Christians. ${ }^{186}$

\subsubsection{Hassan Haltay (1811)}

In 1811 the city of Cartagena was loyal to the government established in Cádiz, which opposed the régime imposed by Napoleon's troops in Madrid, and its port was vital for supplying the provisional capital, which scarcely had access to the rest of Spain. Hassan Haltay ${ }^{187}$ was a merchant from Tripoli, married and relatively young, who styled himself "an overseas trader with a company [located] in several cities." He had limited partnerships in Smyrna, Alexandria, Misrata, Algiers, Gibraltar, Tangier, Fez, and Rabat; in almost all he was the lead investor, with manufacturers or mere employees as the other partners. He shipped products from the colonies (coffee and sugar) and manufactured goods (wool, cloth, and iron) to Muslim countries, from which he imported foodstuffs, especially wheat, to Europe. He lived in a rented house in Cartagena, suggesting a more than temporary residence. He imported grain and oil to both Cartagena and Cádiz, and also wool, wax, honey, nuts, hides, livestock, and other products. Shortly before his death he received, thanks to an intervention by the Ministry of War, 17,50o reales in partial payment for a cargo of wheat he had deposited in the local granary.

In the late summer of 1811 Altay contracted yellow fever, of which he died on 25 or 26 August; but first he was able to make his will. He swore it in the presence of Gerónimo García, a public scribe and secretary of the Tribunals of the Treasury, War, and Foreign Affairs (Tribunales de Hacienda, Guerra y Extranjeros); Ramón Lozano, his commissioner and representative in the city; Juan Bautista Rizo, an interpreter of Arabic; and several Spanish witnesses. Making his father his universal heir, he left his wife only the dowry she had brought to the marriage. The Spanish authorities ordered Caddur, captain of the Algerian tartane Bruch,

186 In the second petition, in which the captain claimed to be the ship's owner, the scribe stated that he had signed both appeals because the captain did not know how to write: 19 December 1807. Correga to Count of Santa Clara, 15 December 1807, I M HB, FS, Serie I, leg. 28 fol. 148 .

187 Also called Hasen b. Altay. His case is found only in Vilar Ramírez, "Musulmanes en la región de Murcia." 
to wrap him in a shroud and prepare [the body] so that it will not decay, placing it in a well-prepared and well-sealed casket; and by means and order of Don Ramón Lozano, of this company, a ship shall be chartered to take the body to his homeland, Tripoli, so that his father may receive and bury it.

Lozano, his executor, paid the captain and settled the merchant's debts and the legal costs of the will for a total of 6,984 reales, which he deducted from the 17,500 previously paid for the load of wheat; what remained was 10,527 reales and 17 maravedís. Nonetheless, a rumor in the city had it that the deceased had left "half a million [presumably reales] in property." The matter was still not settled when, in November 1812, a royal decree from the Ministry of the Treasury embargoed all the property of Tripolitan subjects; its intent was to compensate for illegal seizures by Algerian corsairs of Spanish ships and cargoes.

There was an investigation of Haltay's supposed half million reales, but his executor Lozano continued to insist that there were no more than 10,527; he claimed to have tried to contact Tripoli's consul in Gibraltar in order to hand over that sum. Our sources say nothing more about what happened to the merchant's property, though its true value may well have been disguised and his dying wishes may not have been fulfilled. It is strange that this North African businessman should have no other debts to collect in the city, and owned only the clothes he had on him. It is also possible that his body was never shipped to Tripoli, as specified in his will, but was buried in a field outside the city - although not the one that had received the bodies of free and enslaved Muslims some twenty or thirty years before. ${ }^{188}$

Spain's wars with England and France favored the arrival in Spanish ports of hundreds of vessels from Morocco, Algiers, Tunis, and Tripoli; these helped to ensure that commerce continued between Spain and North Africa, as well as trade between Spanish and many European ports. ${ }^{189}$ Above all, they kept Spanish coastal trade functioning at that perilous time for the Spanish maritime economy. With some exceptions, there was an undoubted Spanish-Moroccan alliance against both French and English attacks, in which Algerians and Tunisians participated to a lesser extent.

188 Vilar Ramírez, "Musulmanes en la región de Murcia."

189 We should also note that several Ottoman polacres sailed the route to the Indies, securing at least in part Spain's trade with its American colonies. 
Thanks to the explosion of Maghrebi shipping, the North African merchant colony in Spanish cities grew more diversified. ${ }^{190}$ Until 1797 the Moroccans were virtually alone, and continued to dominate until 1815 , but traders from Algiers, Tunis, and Tripoli increased steadily in numbers. They were less permanent, most of them being pursers who returned home once their business was completed.

The situations of conflict in which these traders were involved were not substantially different from the ones we saw in Chapter 8 . They do seem to have had a fuller knowledge of the boards of trade in different ports, and visited notaries more often. Their understanding of the Spanish judicial system and mercantile practice improved, as we have seen in several individual cases analyzed in this chapter. Some solid relationships were established with prominent Spanish merchants such as Benito Patrón and Benito Picardo in Cádiz.

But the most important lesson to be drawn from the increased presence of Maghrebi merchants in Spain was that the lack of consuls, commercial attachés, or representatives from their respective countries made it very difficult to defend their interests. They clearly had recourse to petitions and appeals drawn up by Spanish professionals, and while those documents showed the appropriate language and line of argument they were insufficient for resolving the lawsuits and conflicts in which these traders became involved.

We must not exaggerate, however. While the Maghrebis increased their recourse to boards of trade, notaries, and juridical institutions, their excessive faith in direct appeals to the monarch and the Secretary of State continued to be a problem. We will explore this issue in our Epilogue.

Just as in the previous period, between 1797 and 1814 both the Spanish and the Moroccan monarchies strove to prevent incidents between their respective subjects from altering the friendly relations between the two countries. We can say something similar, with certain differences, about Spain's relations with the North African regencies.

190 Historiography on Morocco has held the opposite. See, for example, Daniel Schroeter: "Very few merchants traveled to Europe. The exceptions were well known and often elicited comments in the newspapers or foreign consulates. In the 1820s, one such Muslim merchant was al-Hajj Ahmad Ahardan, a royal tajir, customs official and Makhzan treasurer, who traveled to Marseilles, where he had business connections with Isaac Israel, as well as to England, Naples, Gibraltar, and Cadiz": Schroeter, Merchants of Essaouira, 126. 